SOCORPO PROSPECT AREA

GEOTHERMAL RESOURCE PROSPECT

(SUNEDCO \& GULF MINERALS)

GeothermEx

October 1979 


\section{DISCLAIMER}

This report was prepared as an account of work sponsored by an agency of the United States Government. Neither the United States Government nor any agency Thereof, nor any of their employees, makes any warranty, express or implied, or assumes any legal liability or responsibility for the accuracy, completeness, or usefulness of any information, apparatus, product, or process disclosed, or represents that its use would not infringe privately owned rights. Reference herein to any specific commercial product, process, or service by trade name, trademark, manufacturer, or otherwise does not necessarily constitute or imply its endorsement, recommendation, or favoring by the United States Government or any agency thereof. The views and opinions of authors expressed herein do not necessarily state or reflect those of the United States Government or any agency thereof. 


\section{DISCLAIMER}

Portions of this document may be illegible in electronic image products. Images are produced from the best available original document. 
JAMES B. KOENIG (415) 524-9242

MURRAY C. GARDNER (503) 482.2605

\title{
GEOTHERMAL RESOURCE POTENTIAL \\ OF THE SOCORRO AREA, \\ NEW MEXICO
}

\author{
for \\ GULF MINERAL RESOURCES COMPANY \\ DENVER, COLORADO \\ and \\ SUNOCO ENERGY DEVELOPMENT COMPANY \\ DALLAS, TEXAS
}

by

GeothermEx, Inc.

Berkeley, California

Carol A. Petersen

James B. Koenig

October 1979 
JAMES B. KOENIG (415) 524-9242

MURRAY C. GARDNER (503) 482-2605

CONTENTS

CONCLUSIONS . . . . . . . . . . . . . . . . . 1

RECOMMENDATIONS . . . . . . . . . . . . . . . 4

INTRODUCTION ....................... 5

GEOLOGY . . . . . . . . . . . . . . . . . 5

Regional Setting .. ................ 5

Summary of Stratigraphy . . . . . . . . . . . 6

Precambrian Rocks . . . . . . . . . . . 6

Paleozoic Rocks .. . . . . . . . . . 6

Tertiary Rocks .. . . . . . . . . . . . . 7

Structure ........................ . . . . . 9

GEOPHYSICS. . . . . . . . . . . . . . . . . . . . . . 11

Seismology and Crustal Deformation . . . . . . . . 11

Historical Seismicity . . . . . . . . . . . . 11

Microseismicity . . . . . . . . . . . . . 12

Reflection and Refraction Surveys . . . . . . . . 14

Regional Crustal Structure .. . . . . . . . . 15

Modern Crustal Deformation . . . . . . . . . 15

Gravity and Magnetic Data . . . . . . . . . . 16

INTERPRETATION OF TEMPERATURE DATA . . . . . . . . . . . 17

Temperature . . . . . . . . . . . . . . . . . 17

Temperature Gradients . . . . . . . . . . . . . 17

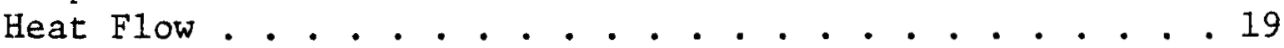

Computations . . . . . . . . . . . . 19

Regional Heat Flow .. . . . . . . . . . . 20

Discussion . . . . . . . . . . . . . . . 21

GROUND WATER . . . . . . . . . . . . . . . . 22

Recharge ..................... 23

Direction of Groundwater Movement . . . . . . . . . . 24

Water Temperature . . . . . . . . . . . . 25

Water Chemistry . . . . . . . . . . . . 26

Total Dissolved Solids . . . . . . . . . 26

Composition of Dissolved Solids . . . . . . . . 28

Mixing Models . . . . . . . . . . . . . 30

Geothermometry . . . . . . . . . . . . . 32

Zones of Thermal Water Circulation . . . . . . . . 33 
JAMES B. KOENIG (415) 524-9242

MURRAY C. GARDNER (503) 482-2605

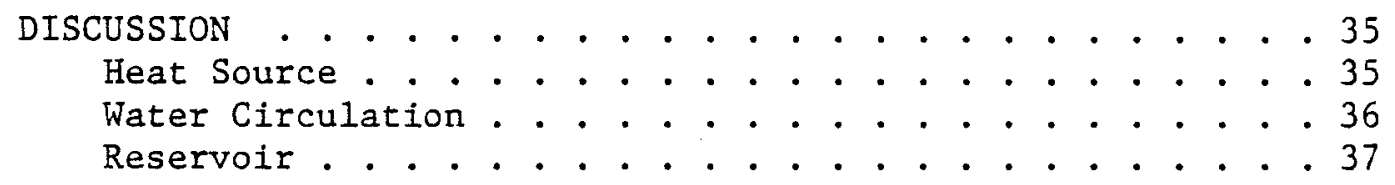

CONTINUED ACTION . . . . . . . . . . . . . . . 37

REFERENCES ...................... . . 40

APPENDIX A. Temperature profiles of gradient holes, Socorro area, New Mexico. 


\section{ILLUSTRATIONS}

Figure

After Page

1. Composite stratigraphic column of the Socorro area . . . . . . . . . . . . . . 6

2. Overlapping and nested cauldrons in the SocorroMagdalena area . . . . . . . . . . . 7

3. Map of well-located reflection points and the outline of the magma body . . . . . . . . . . 13

4. Index map of north-central New Mexico showing shotpoints and recording stations for seismic refraction profiles in the vicinity of the Rio Grande rift . . . . . . . . . . . . 14

5. Terrestrial heat-flow contour map of New Mexico and southern Colorado ........... . 20

6. Mean annual precipitation, in inches, in New Mexico, 1931-1952............. 23

7. Surface drainage areas of La Jencia Creek and Socorro Canyon within the project area... . . 23

8. Average annual evaporation, in inches, from shallow reservoirs in New Mexico, 1946-55 . . . . 23

Table

1. Depths, temperatures, and temperature gradients in the Socorro area, New Mexico . . . . . . . . 17

2. Heat flow data in the Socorro area, New Mexico . . 19

3. Heat flow data for control points in the Socorro area, New Mexico... . . . . . . . . . 20

4. Chemical analysis of springs in the Socorro area, New Mexico................. 26 
JAMES B. KOENIG (415) 524-9242

MURRAY C. GARDNER (503) 482-2605

Table

After Page

5. Chemical analyses of wells in the Socorro area, New Mexico . . . . . . . . . . . . . . 26

6. Major ion and TDS composition of ground water and calculated mixing components, east Magdalena Mountains and Strozzi Ranch area. . . . . . . 30

\section{Plates}

1. Detailed geologic map of the northern Chupadera Mountains, Socorro Peak, and southern Lemitar Range, New Mexico . . . . . . . . . . . . in pocket

2. Generalized geologic map of the Socorro area, New Mexico . . . . . . . . . . . . . . in pocket

3. Distribution of microearthquakes and postulated shallow magma bodies in the Socorra area. . . . . in pocket

4. Residual Bouguer gravity map of the Socorro area . . . . . . . . . . . . . . . in pocket

5. Residual magnetic intensity map of the Socorro area . . . . . . . . . . . . . . . . in pocket

6. Depths, bottom-hole temperatures and characteristic temperature gradients of drill holes in the Socorro area, New Mexico . . . . . . . . . In pocket

7. Heat flow in the Socorro, New Mexico, area... . In pocket

8. Index to groundwater data and water table elevations in the Socorro area ........... in pocket

9. Major ion composition of ground water in the Socorro area............... . in pocket

10. Relative composition of ground water from various parts of the Socorro area . . . . . . . . . in pocket 
JAMES B. KOENIG (415) 524-9242

MURRAY C. GARDNER (503) 482-2605

\author{
CONCLUSIONS
}

1. Prior discussions of the geothermal potential of the Socorro area have been based on the premise that magma bodies are present at shallow depth ( 12 miles and possibly about 2 miles) beneath an 01igocene-age caldera. However, temperature gradient, heat flow, and hydrochemical data fail to identify any strong thermal anomalies in the project area.

2. Analyses of seismic data shows that the widespread magma bodies are at mid-crustal depths ( 12 miles, or $19 \mathrm{~km}$ ) and are quite thin (about 3,000 feet or $1 \mathrm{~km}$ ). If fully molten, these bodies could impose an equilibrium conductive temperature gradient of only $3^{\circ} \mathrm{F} / 100 \mathrm{ft}\left(55^{\circ} \mathrm{C} / \mathrm{km}\right)$. If the magma bodies are very youthful (they are semi-liquid despite their thinness), conductive temperature equilibrium to the surface may not yet be established. That is, the shallow crust may still be warming.

3. Maximum bottom hole temperatures are $90^{\circ} \mathrm{F}\left(32.0^{\circ} \mathrm{C}\right)$ in $\mathrm{B} 40$, and $81^{\circ} \mathrm{F}\left(27.2^{\circ} \mathrm{C}\right)$ in $\mathrm{A} 3$. Holes $\mathrm{B} 20, \mathrm{~B} 35, \mathrm{U} 3, \mathrm{U} 4$, and $\mathrm{A} 1 \mathrm{~B}$ have temperatures in the $77-79^{\circ} \mathrm{F}\left(25-26^{\circ} \mathrm{C}\right)$ range.

4. The highest temperature gradient measured at moderate depth (165-1,391 feet, or 50-424 m) in the Socorro area which may represent equilibrium conditions is $3.1^{\circ} \mathrm{F} / 100 \mathrm{ft}\left(55.5^{\circ} \mathrm{C} / \mathrm{km}\right)$ in B15. Several holes have gradients of $2.2-2.8^{\circ} \mathrm{F} / 100 \mathrm{ft}$ $\left(40-50^{\circ} \mathrm{C} / \mathrm{km}\right)$ below 330 feet $(100 \mathrm{~m}): \mathrm{S} 2 \mathrm{~B}$, NM5, $A 1 B, A 6 B, B 31$, $B 33,58, S 9 B$. These are close to the predicted equilibrium conductive gradient.

5. The deeper holes, especially B40 and B35, have high gradients (to $7.1^{\circ} \mathrm{F} / 100 \mathrm{ft}$ or $128.7^{\circ} \mathrm{C} / \mathrm{km}$ ) in their upper portions, but have isothermal or reversed gradients at bottom along with moderate bottom-hole temperatures, demonstrating deep groundwater circulation. High gradients are seen at shallow levels in many shallow ( 130 feet or $40 \mathrm{~m}$, or less) holes, but the persistence of the high gradients with depth is moot, given the experience of $B 40$ and $B 35$.

6. Regional conductive heat flow probably is closer to 2.0 than to HFU. Higher published estimates probably are erroneous, because they were computed for shallow holes and shallow convective disturbance is likely. Six holes in the project area 
have heat flow greater than $2.0 \mathrm{HFU}$, but heat transfer by groundwater convection is proven at 4 of these points and is very probable at the other two. Thus, no greater-than-average conductive heat transfer has been demonstrated.

7. Most of the computed heat flow values are subaverage and suggestive of convective disturbances. Those in the La Jencia Creek-Nogal Canyon area are so low (less than $1.0 \mathrm{HFU}$ ) that they demonstrate deep cool groundwater circulation.

8. Moderate quantities of $c 001$ groundwater move from recharge areas on the flanks of the Magdalena Mountains through the La Jencia Creek and Socorro Canyon areas. In addition, a zone of upwelling cool dilute groundwater has been demonstrated from hydrochemical, temperature-gradient, and heat-flow data in the Strozzi Ranch area west of Socorro Peak.

9. Socorro, Sedillo, and Cook Galleries on the east side of Socorro Peak have mildly thermal water, whose temperature, composition, and calculated reservoir temperatures all are consistent with circulation to only moderate depth in a region of $1.7-2.8^{\circ} \mathrm{F} / 100 \mathrm{ft}$ $\left(30-50^{\circ} \mathrm{C} / \mathrm{km}\right)$ temperature gradient. No strong thermal component is indicated.

10. Only well 非67 on the east side of the Socorro Peak block has hydrochemical evidence of a deep, hot circulation $\left(295^{\circ} \mathrm{F}\right.$, or $146^{\circ} \mathrm{C}$ reservoir temperature calculated by $\left.\mathrm{Na}-\mathrm{K}-\mathrm{Ca}\right)$. $\mathrm{SiO}_{2}$ geothermometry yields much lower values (not over $165^{\circ} \mathrm{F}$ or $74^{\circ} \mathrm{C}$ ). A presumptive case for mixing with deep, hot, chlorided water can be made, but with limited confidence.

11. Regional geologic structure and subsurface section remains poorly understood. Presumed Oligocene volcanic cauldrons are not recognizable in surface fault patterns, and impose difficult requirements in geologic cross-sections.

12. Deep aquifers may exist in Paleozoic limestones or more shallowly in any of several Tertiary volcanic-sedimentary units. No single model of subsurface geology, hydrology, thermal regime and hydrogeochemistry is fully convincing. However, a reasonable hypothesis is that cool groundwater recharging to perhaps several thousand feet masks or dilutes the heat rising conductively from a mid-crust magma. 
JAMES B. KOENIG (415) 524-9242

MURRAY C. GARDNER (503) $482-2605$

13. Continued exploration and leaseholding depends upon the assumptions that: (a) a thermal anomaly is present along the east side of Socorro Peak, extending to the west at depth; (b) the anomaly to the west is masked by $\operatorname{cool}$ groundwater circulating to an unknown depth; and (c) the anomaly is not too deep to encounter in continued drilling. A11 3 assumptions are debatable.

14. It is unlikely that further shallow drilling can resolve these questions. Future gradient holes will have to go to 2,000-2,500 feet in depth, to determine circulation patterns, deep gradients and subsurface geologic section. If fluid samples can be obtained from such deep holes, geochemistry may help in interpreting the groundwater-circulation patterns. 
JAMES B. KOENIG (415) 524-9242

MURRAY C. GARDNER (503) 482-2605

\author{
RECOMMENDATIONS
}

1. Drill one or two 2,000-2,500-foot holes in the Socorro Peak block to define temperature conditions and deep circulatory system at depth. If feasible, collect fluid samples for comparative geochemical analysis and geothermometry.

2. Because data from an imtermediate-depth hole in the northern Chupadera Mountains showed circulation of only moderate temperature water at depth, no further drilling is recommended there.

3. If further drilling is contemplated, sample selected springs and wells in the Socorro Peak block and Strozzi Ranch area to obtain complete hydrochemical and isotope analyses, which may be used for improved calculation of reservoir temperatures and mixing models.

4. Additional shallow (less than 330 feet or $100 \mathrm{~m}$ ) temperaturegradient drilling is not warranted at this time.

5. If no further exploration is budgeted or planned, retain those leases that require no performance and that have low annual rentals. Inquire about possible farm-outs based on the recipient drilling several 2,000-2,500 foot holes.

6. Update information on the status of institutional research into the seismology, chemistry and geology of the presumed magmatic bodies before abandoning leases. 


\section{INTRODUCTION}

This report provides a regional synthesis of geology, geochemistry, hydrology and geophysical data for the Socorro, New Mexico, area. It is based principally on extensive drill-hole data supplied by, and proprietary to, Gulf Mineral Resources Company and Sunoco Energy Development Co. These temperature-gradient and heatflow data are integrated with older gradient and heat-flow data, groundwater chemistry, studies of local seismicity, regional and local geologic mapping, and other data. This synthesis yields a revised estimate of the geothermal energy potential for the Socorro area. It should be recalled that attention has been focused on Socorro and vicinity because of reported high heat flow and probable magmatic bodies within the shallow crust.

Some 20 man-days of effort have gone into this study, exclusive of time spent earlier in logging temperature gradients and studying drill-hole cuttings.

\section{GEOLOGY}

\section{Regional Setting}

The Socorro area lies within the Rio Grande rift, a 400mile-long north-trending zone of en echelon fault-bounded basins, which are characterized by basalt and rhyolite volcanism and thin red crust. The rift has been interpreted by many workers as an intracontinental zone of crustal spreading.

The rift is bordered on the west by the Colorado Plateau and the southern part of the Basin and Range province and on the east by the High Plains. The rift generally is agreed to include Las Cruces, New Mexico on the south and the San Luis Valley in Colorado on the north. However, various authors have proposed different western and eastern boundaries as well as different northern and southern endpoints for the rift, as geological and geophysical models of the region have evolved. For example, Kelley (1952) drew the western boundary of the Rio Grande rift at Socorro along the base of the Socorro Peak block, implying that the rift is much narrower at this latitude than to the north. However, Chapin et al. (1978) described the Chupadera Mountains-Socorro PeakLemitar Range as an interbasin horst, and placed the boundary of 
JAMES B. KOENIG (415) 524-9242

MURRAY C. GARDNER (503) 482.2605

the Rio Grande rift at Socorro at least as far west as the flank of the Magdalena Mountains.

It is beyond the scope of this report to discuss regional development of the rift; instead it will concentrate directly on the Socorro area, especially those factors related to possible geothermal resources.

\section{Summary of Stratigraphy}

A detailed geologic map of the northern Chupadera Mountains, the Socorro Peak block, and the Polvadera Mountain part of the Lemitar Range is given in plate 1 . Less-detailed information covering the east flank of the Magdalena Mountains, as well as the Chupadera-Socorro Peak-Lemitar Mountains, is shown on plate 2 . A composite stratigraphic column (figure 1) summarizes the lithology and thickness of the various units.

\section{Precambrian Rocks}

Precambrian basement rocks underlie a large part of the Magdalena Mountains in T. 2 and 3 S., R. 3 W. The principal rock types are argillite and schist, which were formed by low-grade regional metamorphism of clay-rich sediments, and a later granitic batholith.

In the Socorro Peak area, Precambrian rock is exposed only in Sec. 4, T. 3 S., R. 1 W. (plate 1). It probably is similar in lithology to extensive outcrops along the east side of Polvadera Mountain in Sec. 31 and 32, T. 1 S., R. 1 W. and in Sec. 5 and 6 , T. 2 S., R. 1 W. Here, Precambrian units include mafic and felsic plutonic rocks, gneiss, quartzite, argillite, and schist.

Exposure of Precambrian rocks in the center of the Socorro Peak and Lemitar horsts implies that these areas have undergone profound uplift.

\section{$\underline{\text { Paleozoic Rocks }}$}

Lower Paleozoic rocks are not present in the Socorro area, probably as a combined result of non-deposition and erosion. 


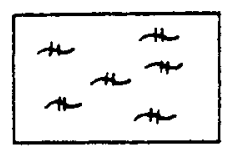

Rhyolite

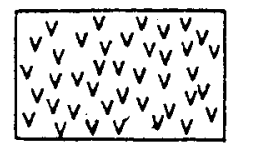

Tuff

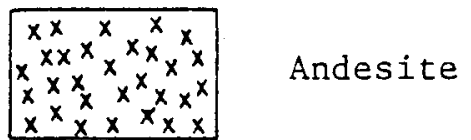

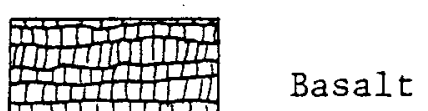

Pasalt

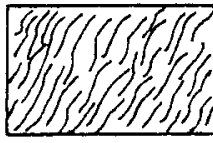

Schist

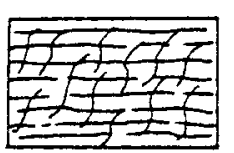

Argillite

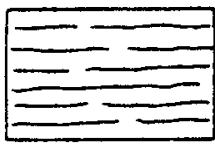

Clay and Shale

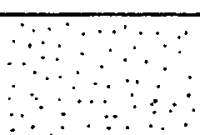

Sand

$\therefore: 00: 0$

$\because: 00: 0$

Grave1

.00000

Gravel

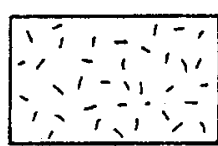

Granite

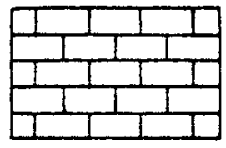

Limestone 


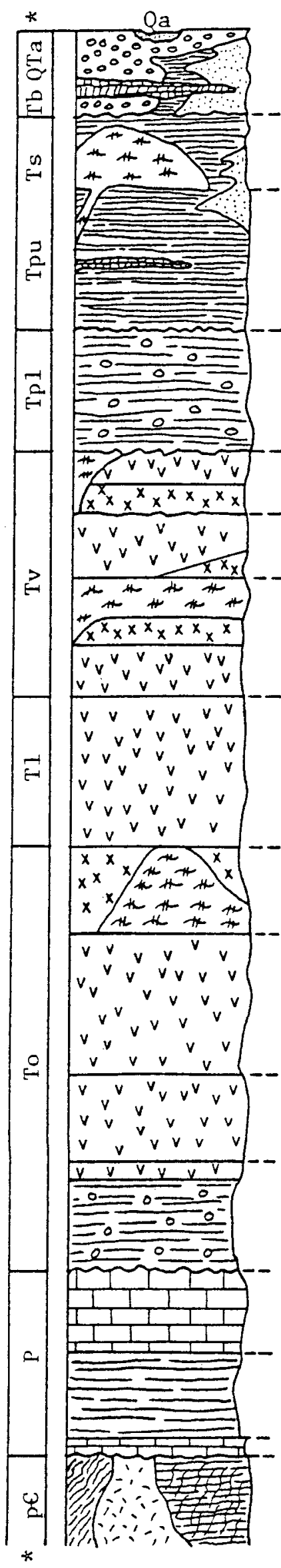

Sierra Ladrones Formation: (0-1000'). Piedmont-slope, river-channel, flood-plain deposits, and basalt flows.

Rhyolite of Socorro Peak: 7-10 m.y. (0-800'). Silicic domes, flows, tuffs.

Upper Popotosa Formation: (0-2500'). \{Member of Kelly Ranch Claystones, mudstones, siltstones, sandstones, conglomerates, and basalt flows.

Lower Popotosa Formation: (0-1500'). \{Members of Socorro Canyon and Lemitar Mountains.\} Mud flow deposits, fanglomerates, and minor lacustrine deposits.

Lavas of Water Canyon Mesa: $20 \mathrm{~m} . \mathrm{y} \cdot\left(0-600^{\prime}\right)$. Intermediate to silicic lavas and tuffs. Locally present, east flank of Magdalena Mountains.

Tuff of South Canyon: 26 m.y. $\left(0-600^{\prime}\right)$. Ash-flow tuffs. Tongue of basaltic andesite.

Luis Lopes Formation: (0-2000'). Ash-flow tuffs, andesitic lavas, rhyolitic domes and tuffs, minor landslide deposits.

Lemitar Tuff: $27 \mathrm{~m} . \mathrm{y},\left(0-400^{\prime}\right.$ outflow, 700-2900' cauldron). Ash-flow tuffs; multiple units.

Unit of Six Mile Canyon: (0-200')/ Andesite to basaltic andesite lavas, rhyolite lavas and domes, ash-flow tuffs, laharic breccias. Locally present, east flank of Magdalena Mountains.

A-L Peak Tuff: 32 m.y. (0-700' outflow, 2000'+ cauldron). Ash-flow tuffs, multiple units.

He11's Mesa Tuff: 32-33 m.y. (0-500' outflow, 3000'+ cauldron). Ash-flow tuffs, multiple units.

Spears Formation: 33-37 m.y. (0-1500'). Conglomerates, mudflow deposits, lavas, and ash-flow tuffs.

Madera Limestone: (500-1500').

Sandia Formation: (550-650'). Shales, quartzites, and limestone.

Kelly Limestone and Caloso Formation, undivided: (0-90'). Precambrian crystalline basement: Mafic and velsic plutonic rocks, schist, gneiss, argillite, and quartzite.

* Lithologic units shown on Plate 2.

FIGURE 1. Composite stratigraphic column of the Socorro area. Thickness of units not to scale. (Modified from Chapin et al., 1978.) 
Closest exposures of lower Paleozoic rocks are about 40 miles south of the project area.

The oldest Paleozoic units present, the Mississippian Kelly and Caloso Formations undivided, were deposited directly onto eroded surfaces of the Precambrian rocks. In the Kelly mining district on the northeast side of the Magdalena Mountains, the Kelly limestone was very permeable to hydrothermal fluids during stock intrusion and ore deposition. However, this unit is relatively thin (0-90 feet), and it alone could not provide adequate storage for a commercial geothermal system.

The overlying Pennsylvanian Sandia Formation, which is composed of shale with minor quartzite and limestone, acted as an impermeable cap above the Kelly limestone during the ore-forming episode.

At the top of the local Paleozoic section, the Madera Limestone (500-1,500 feet thick) is permeable and is thick enough to be a potential host for geothermal fluids.

\section{Tertiary Rocks}

Neither Mesozoic nor lower Tertiary rocks are present in the Socorro area. Such units may have been deposited, but subsequently were removed by erosion. Mesozoic rocks crop out about 10 miles east of the project area.

\section{Oligocene}

Volcanic activity began in the Socorro area in early Oligocene time with deposition of the Spears Formation (37-33 m.y.), which is composed largely of volcaniclastic debris but also contains ash-flow tuffs of intermediate composition. The Spears Formation has not been correlated with a specific volcanic center.

According to Chapin et al. (1978), a series of nested cauldrons formed in the Socorro-Magdalena region (figure 2) during the period 33-26 m.y. ago (early Oligocene to latest Oligocene). Volcanic units named in figure 1 are correlated with these volcanic centers as follows: The Hells Mesa tuff probably was derived from the North Baldy cauldron. Various members of the A-L Peak tuff were produced from the Mt. Withington, Magdalena, and Sawmill Canyon cauldrons, while the unit of Sixmile Canyon represents infill of the Sawmill Canyon cauldron. The Socorro 


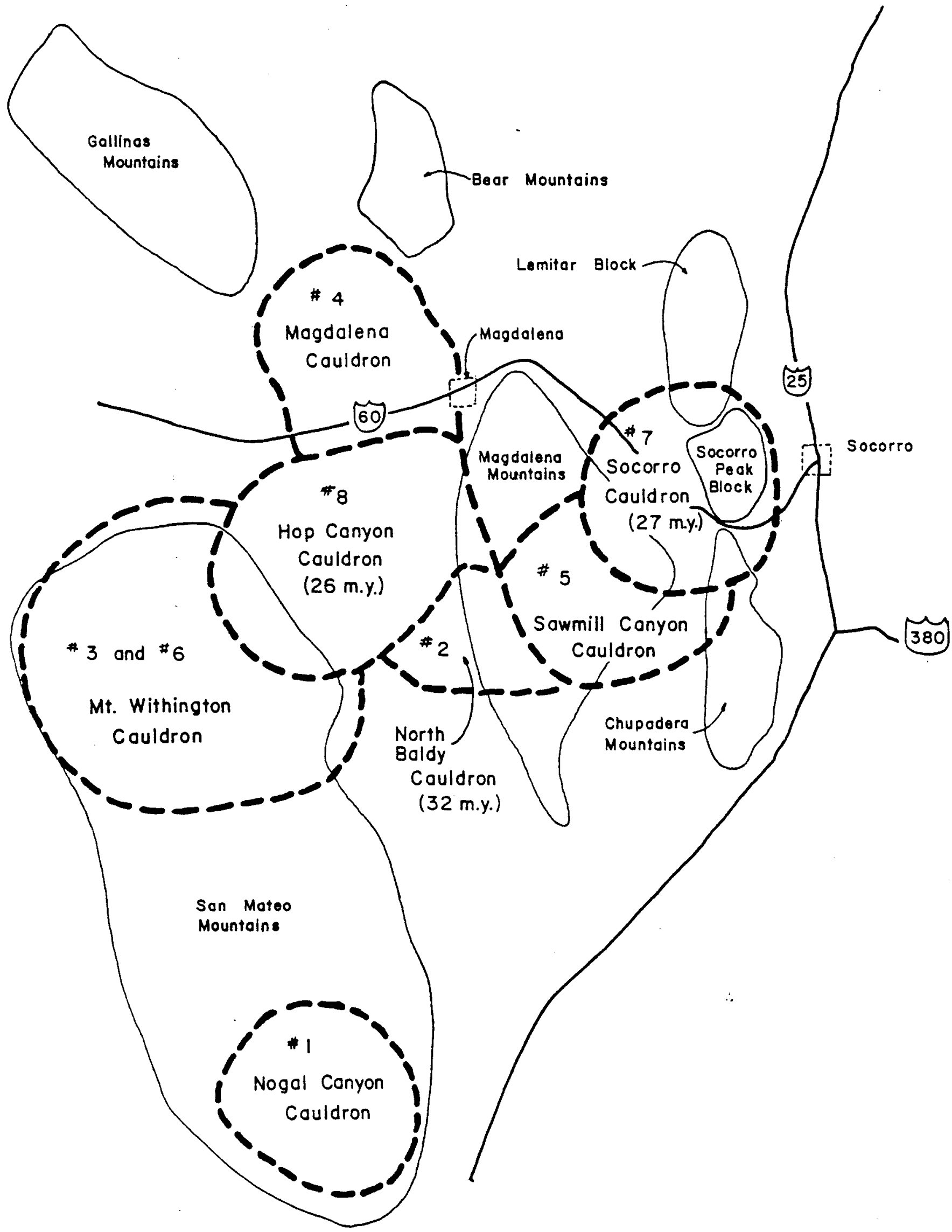

Figure 2. Overlapping and nested couldrons in the Socorro-Magdalena orea. Numbered in sequence from oldest to youngest. (Modified from Chopin et 의, 1978) 
cauldron was the source of the Lemitar tuff, and the unit of Luis Lopez represents infilling and resurgent volcanism within the Socorro cauldron. The tuff of South Canyon is a regional unit that was deposited over the Socorro cauldron; its source may have been the Hop Canyon cauldron.

Owing to the differing thickness of caldera-fill and outflow facies of ash-flow units, and the overlapping of calderas, as well as possible post-deposition episodes of erosion, the thickness of volcanic rocks varies greatly between localities.

The great effusion of volcanic units in the Socorro-Magdalena area tapered off at the end of the 01igocene. Some volcanic units, such as the lavas of Water Canyon Mesa, are of Lower Miocene age, but these units are much less voluminous and are relatively restricted in area.

Finally, it should be noted that existence of the several cauldrons and the sequential interrelationship of volcanic units is inferred from indirect evidence of rock type, thickness, particle size, and geophysical parameters. Surface fault patterns do not strongly support cauldron formation.

\section{Miocene}

During Miocene time, a broad alluvial basin developed, including the Magdalena area on the west and the present course of the Rio Grande River on the east. The north and south boundaries of the basin are not well known. Thick sediments (at least 3,000 feet) of the Popotosa Formation (Santa Fe Group) accumulated within this basin.

Areas presently standing at high elevation were part of the lowlands receiving sediments, as is inferred from the presence of Popotosa Formation at the crest of the Magdalena Mountains in Sec. 6 and 7, T. 4 S., R. 3 W., (Krewedl, 1974) at an elevation slightly above 10,000 feet. The area presently occupied by the ChupaderaSocorro Peak-Lemitar uplift was persistently a low-lying part of the Popotosa basin, tending to receive the finest-grained sediments (Chapin et a1., 1978).

Some lower Miocene volcanic units are known, such as the lavas of Water Canyon Mesa, but these appear to be of local distribution. 
Upper Miocene rhyolitic domes and flows of the Socorro Peak group (7-12 m.y.) are interbedded with the upper Popotosa Formation. These are the youngest silicic volcanic units known in the Socorro area. It appears likely that even if these silicic lava flows are the surface expression of a mid- to shallow-crustal silicic pluton, this episode is too old to serve as a present-day heat source for geothermal fluids.

\section{$\underline{\text { P1iocene }}$}

Between $7 \mathrm{~m} . \mathrm{y}$. (youngest Socorro Peak rhyolites extruded) and $4 \mathrm{~m} . \mathrm{y}$. (basalts of Sedillo Hill emplaced), the Popotosa basin was broken by uplift. Integration of the ancestral Rio Grande drainage also occurred at this time. Sediments of the Sierra Ladrones Formation accumulated throughout the Pliocene epoch, intercalated with local basalt flows, such as those at Sedillo Hill. This appears to have terminated extrusive volcanism in this region.

\section{Pleistocene and Recent}

Minor alluvial sedimentation occurred throughout Quaternary time. However, the cutting of several geomorphic surfaces as a function of aggradation of the Rio Grande River was the most important geologic event.

\section{Structure}

As can be seen from plates 1 and 2, faults in the Chupadera Mountains-Socorro Peak-Lemitar Range uplift most commonly trend north-northwest and have normal offset. Northeast-trending faults, possibly somewhat older, are common in the northern Chupadera Mountains. In the eastern part of the Magdalena Mountains, faults show much more curvature than do those to the east, but their general linear trend is north-northwest. A special class of faults in the Socorro Peak block and the Lemitar Range consists of those which originally were normal faults of moderate dip, but which now are nearly flat-lying or have apparent reverse offset as a result of subsequent tilting and rotation. These faults chiefly offset Paleozoic units.

However, there has been movement on the north-northwest-trending faults throughout the project area since mid-Miocene, because upper 
Popotosa Formation and younger units are offset. Many faults have moved in Pleistocene or Holocene time, because they offset unconsolidated alluvium of probable Quaternary age. Some mapped faults, especially those along the east side of the Magdalena Mountains and those east of the Chupadera Mountains, have fresh scarps and offset alluvium at the surface, indicating very recent movement.

These faults appear to be related to breakup of the Popotosa sedimentary basin, upwarping of the Magdalena Mountains and raising of the Chupadera-Socorro Peak-Lemitar uplift. Presumed ring-faults, associated with caldera collapse, are less obvious; and the outline of the Socorro cauldron shown on plate 2 by Chapin et al has 1ittle apparent correlation with mapped faults.

Chapin et al. (1978) proposed a larger-scale structural element in the Socorro area: a transverse shear zone crossing both the Socorro Peak block and the Magdalena Mountains. On the north side of this presumed shear zone, formations are tilted to the west and stepped down to the east by north northwest-trending normal faults; whereas on the south side of the shear zone, formations are tilted to the east and stepped down to the west. Chapin et al. suggested that this transverse shear zone controls the south edge of a postulated present-day deep magma body. They also implied that the zone controlled emplacement of the late Miocene Socorro Peak rhyolites and development of the oligocene cauldrons, reasoning that this structure must represent a deep-seated structural flaw. Furthermore, they implied that present-day hydrothermal circulation patterns may be strongly influenced by this shear zone.

However, similar zones of reversed fault dip and rotation are found at many places in the western United States including a few geothermal prospects. Notable amongst the latter is the Warner Range of Oregon and California, which exhibits different rotational style to the north and south of Fandango Pass. Various explanations have been proposed, for this phenomenon, including diagonal strike-slip faulting, doming, and regional crustal extension. The significance, cause, and even the existence of such transverse shear zones remains moot. If demonstrated to exist, a magmatic relationship is highly presumptive.

Regionally, the Socorro area lies within the Rio Grande rift zone at its intersection with the Morenci lineament, a northeasttrending zone of mineralization and deep-seated structural grain. Several other lineaments are known in New Mexico and adjacent states, with and without geothermal significance. Structural-mineralized 
JAMES B. KOENIG (415) 524-9242

MURRAY C. GARDNER (503) $482-2605$

belts associated with geothermal systems include the Pioche-BeaverTushar belt, which extends through the Roosevelt Hot Springs geothermal system in southwestern Utah. It is moot if a causal relationship exists between such lineaments and present-day hydrothermal systems.

\section{GEOPHYSICS}

Geophysical data, particularly evidence from seismic studies, have had a critical influence on the modeling of possible geothermal systems in the Socorro area. Indeed, were it not for strong geophysical evidence of present-day magma bodies at moderate and shallow crustal depths, the Socorro area would not appear much more promising than many other broad areas of crustal extension in the western United States.

In the following sections, seismic and other data will be discussed and integrated with the geologic data.

\section{Seismology and Crustal Deformation}

\section{Historical Seismicity}

Sanford et al. (1979) summarized available data on instrumentally recorded earthquakes (covering the period 1962-1977) and on non-instrumented reports (covering the period 1849-1962). They found that nearly all felt earthquakes occurred along the Rio Grande rift from Socorro to Albuquerque, and that the greatest proportion (75\%) occurred in the 47 mile segment of the rift from Socorro to Belen. A similar spatial pattern was found among instrumentally recorded earthquakes.

Of special interest is an earthquake swarm at Socorro which lasted for 8 month. in 1906-1907. The largest shocks were of intensity 7 to 8 (Modified Mercalli Scale) and calculated magnitude 4.44.9, or perhaps somewhat higher. Elsewhere, earthquake warms of this type have been correlated with magmatic intrusion at shallow depth.

During a 16-year period (1962-1977) of instrumental data, there has been a low level of seismicity in the Rio Grande rift. The highest magnitude reported was 3.6 ; and certain large segments 
of the rift (such as from Socorro to Las Cruces) had no events greater than 2.4. This level of activity is no greater than that observed in the neighboring Colorado Plateau and High Plains provinces, which would be expected to have generally low activity. Sanford et al. (1979) suggested that the Rio Grande rift undergoes episodic seismic activity, with the recent instrumental data representing a quiescent, background level of energy release. Certainly, there were fewer earthquakes than would be expected from the previous 100 years of popular report, and smaller earthquakes than might be expected from the prominent recent fault scarps in the Socorro area.

\section{Microseismicity}

Much study of instrumental records of microseismic events has been undertaken, especially for events in the Socorro area. Sanford et a1. (1979) summarize the results as follows: microearthquake hypocenters are scattered over a 900 square mile $(2,300$ $\mathrm{km}^{2}$ ) area, which is centered roughly over a postulated mid-crustal magma body (discussed below). Activity is somewhat more frequent within the old Socorro cauldron than elsewhere in the Rio Grande rift; but nowhere can recorded hypocenters clearly be correlated with mapped faults.

The focal depths of microearthquakes have been studied using several different techniques; most focal depths are at about 4 miles $(7 \mathrm{~km})$ and none are deeper than 8.5 miles $(13.5 \mathrm{~km})$. Sanford et al. (1979) attributed the lack of deeper earthquakes to abnormally high temperatures at depth, which inhibits stick-slip movements. However, it should be noted that earthquakes occur at focal depths less than $15 \mathrm{~km}$ in many provinces of small crus.tal thickness.

\section{Midcrustal Magma Body}

The most important result of microearthquake studies in the Socorro area is the development of evidence for a widespread midcrustal zone of very low rigidity, thought by many to be magma body. These data were first presented by Sanford and Long (1965) and Sanford et al. (1973); they have been summarized and integrated with new results by Rinehart et al. (1979).

The magma body was identified from unusual reflections of shear waves generated by microearthquakes. These reflections are 
JAMES B. KOENIG (415) 524-9242

MURRAY C. GARDNER (503) 482-2605

$S$ to $P$ and $S$ to $S$ reflections off a sharp discontinuity, which is at a depth fo 12.0 miles $(19.3 \mathrm{~km})$ at. Socorro and dips very slightly (less than $2^{\circ}$ ) northward. The reflector horizon covers an area of about 665 square miles $(1,700 \mathrm{~km} 2)$, from Socorro northward at least 35 miles $(56 \mathrm{~km})$, although the west, north, and east boundaries of the reflector are not well defined (figure 3).

The reflector horizon probably is a sill-like intrusion which contains at least a partial melt, but which certainly has very low rigidity. This conclusion was reached by Rinehart et al. (1979) because no reasonable combination of contrast in solid rock densities across the reflector horizon could yield the observed reflected waves. Only if the interface were composed of solid rock above and either liquid magma or a partial melt below, would the observed reflections fit theoretical values very well.

That the magma body is relatively thin compared to its lateral extent is shown by very small $P$-wave residuals for teleseisms, indicating that the magma layer is 2,000-4,000 feet $(0.6-$ $1.2 \mathrm{~km}$ ) thick if it is composed of a full melt (Rinehart et al., 1979).

\section{Shallow Magma Bodies}

Chapin et al. (1978) summarized evidence for the existence of small, shallow magma bodies within the project area. The distribution of these bodies is shown in plate 3. Detailed instrumental studies of microearthquakes in the Socorro area have shown that, depending on the instrument array used, SV waves through certain areas are very weak or are absent. This screening of SV waves can be explained if liquid magma or a partial melt is present within the zones illustrated. Calculation of Poisson's ratio for microearthquakes in the same area yields anomalously high values, which can be explained by the same distribution of shallow magma bodies.

Finally, Chapin, et al. (1978) reported that detailed threedimensional analyses of the distribution of microearthquake hypocenters shows events to occur around, but not within, the postulated shallow magma bodies except at very shallow depths (less than 8,200 feet to $2.5 \mathrm{~km}$ ). The magma within these shallow zones is thought to be in thin, discontinuous dikes with relatively small total volume. The top of the shallow magma zone may be at about 8,200 feet $(2.5 \mathrm{~km})$.

Whether these shallow magma bodies could provide adequate heat to power a significant geothermal convection system is not known. 


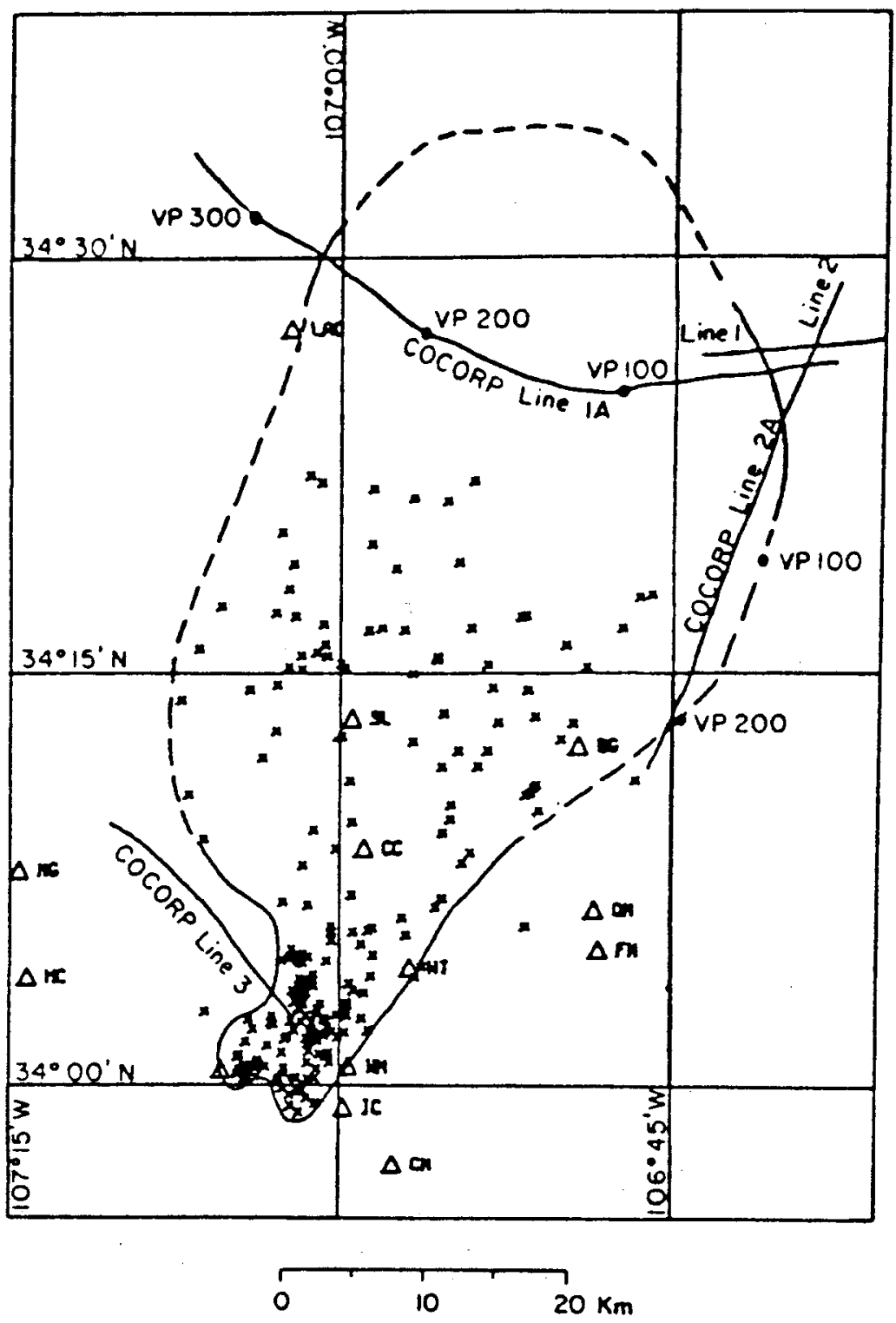

FIGURE 3. Map of well-1ocated reflection points and the outline of the magma body. Also shown are the COCORP lines used to help determine the body's extent. Solid boundaries indicate actual extent while dashed lines indicate a minimum extent. (From Rinehart et al., 1979). 
More fundamentally, whether these shallow magma bodies could remain in the molten state at such shallow depth for more than a brief time interval also remains unknown.

\section{Unpublished Microearthquake Survey}

A detailed microearthquake survey was performed during 3 weeks in 1974 in the Socorro area for Gulf Mineral Resources Company. During this time, 58 local events were recorded, whose magnitudes ranged from -1.1 to +1.1 . The distribution of best-located events is shown on plate 3 along with calculated focal depths; however, neither position nor depths are known with great accuracy. As can be seen from plate 3, the distribution of events recorded during this brief survey generally corresponds to the pattern observed for longer-term studies.

The events located in Sec. $17,18,19$, and $29, \mathrm{~T} .3 \mathrm{~S}$. , R. $2 \mathrm{~W}$. may define an active fault which strikes $\mathrm{N} 10^{\circ} \mathrm{W}$, dips about $80^{\circ} \mathrm{E}$. , and is downdropped to the east. This interpretation is consistent with recent fault scarps mapped nearby. The other events are too poorly located to interpret with confidence.

\section{Reflection and Refraction Surveys}

Brown et al. (1979) reported the results of several COCORP Vibroseis surveys, including a WNW-ESE profile across the Rio Grande rift about 25 miles $(40 \mathrm{~km})$ north of Socorro and a NNE-SSW profile along the east side of the rift, the south end of which is about 9 miles $(15 \mathrm{~km}$ ) from Socorro. The locations of parts of these profiles are shown on figure 4.

Brown et al. found a strong reflector horizon at 12.5 miles $(20 \mathrm{~km})$ depth, corresponding with the location of the postulated Socorro magma body. Detailed interpretation of the reflection data shows that a magma body is consistent with the observed patterns, but is not required by the earth model. If the magma body hypothesis is correct, then the reflection survey results indicate that it is not a simple body but may be layered and/or discontinuous in places.

01sen et al. (1979) reported the results of a seismic refraction profile that used a chemical explosion as the energy source. The line of profile trends NNE and is located about 15 miles $(25 \mathrm{~km})$ 


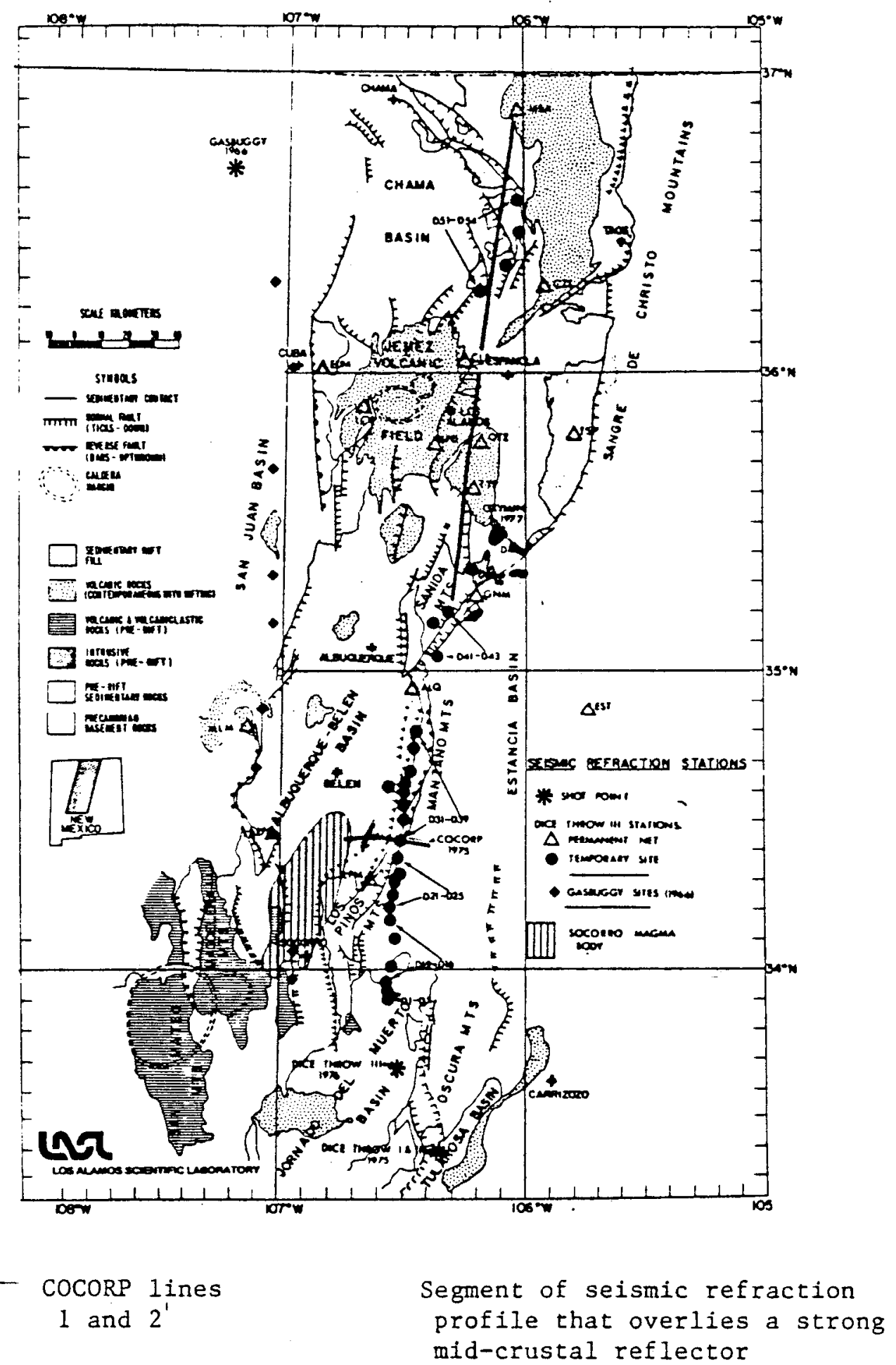

FIGURE 4. Index map of north-central New Mexico showing shotpoints and recording stations for seismic refraction profiles in the vicinity of the Rio Grande rift. (From olsen et al., 1979). 
JAMES B. KOENIG (415) 524-9242

MURRAY C. GARDNER (503) $482-2605$

east of Socorro (figure 4), far to the east of the Socorro magma body as identified from microearthquake data. However, a strong reflector phase at a depth of about 13 miles $(21 \mathrm{~km})$ also was found along this profile. The data show that $P$-waves are reflected from a major intracrustal layer, which has $P$-wave velocity of $2,000 \mathrm{ft} / \mathrm{sec}(6.4 \mathrm{~km} / \mathrm{sec})$, compared to velocities of $19,700 \mathrm{ft} / \mathrm{sec}$ $(6.0 \mathrm{~km} / \mathrm{sec})$ in the overlying units, and also has anomalously low shear wave velocities.

East-west dimensions of this intracrustal 10w-rigidity layer are not known, but its north-south extent is about 68 miles $(110 \mathrm{~km})$. It probably is only a few kilometers thick. Olsen et al. (1979) also suggested that this eastern intracrustal low-rigidity layer may have a lower degree of partial melt than the postulated Socorro magma body.

\section{$\underline{\text { Regional Crustal Structure }}$}

Keller et al. (1979) used Rayleigh wave group and phase velocity measurements and also seismic refraction data to establish the thickness of the crust in the Rio Grande rift. They found that it is about 22 miles $(35 \mathrm{~km}$ ) thick, which is substantially less than the neighboring Colorado Plateau (28 miles or $45 \mathrm{~km}$ thick) or the southern Great Plains ( 31 miles or $50 \mathrm{~km}$ ). The crust within the rift may be slightly thinner in the south, near Las Cruces, than in the north.

If there is any difference in crustal thickness between the Rio Grande rift and the southeastern Basin and Range province, it cannot be resolved from the available data.

\section{Modern Crustal Deformation}

That crustal deformation presently is occurring in the Socorro region is shown by analysis of releveling of elevation lines (Reilinger and Oliver, 1976). The maximum offset reported along a south-to-north line in the Rio Grande Valley is 8 inches $(20 \mathrm{~cm})$ of uplift at a point 14 miles $(23 \mathrm{~km}$ ) north of Socorro. This offset occurred during the period 1911 to 1951, yielding an average rate of 1 inch per 5 years $(0.5 \mathrm{~cm} / \mathrm{yr})$.

Lesser amplitudes of uplift exist both north and south of this maximum point. Overall, the zone of uplift extends from 9 
JAMES B. KOENIG (415) 524-9242

MURRAY C. GARDNER (503) 482-2605

miles (15 km) south of Socorro to 35 miles $(55 \mathrm{~km}$ ) north of Socorro, and is almost directly over the postulated Socorro magma body. Several authors have stated that the observed vertical movements are caused by inflation of the magma body; this remains moot.

It should be noted that there is no east-west profile across the Socorro Peak block, and therefore the degree of modern uplift across the project area is not known.

\section{Gravity and Magnetic Data}

The only available published gravity map of the Socorro area is a residual Bouguer gravity map (plate 4). It shows gravity highs over the Lemitar Range and over the Precambrian-Paleozoic outcrop of the Socorro Peak block, with lesser maxima over the northern Chupadera Mountains. Gravity values rise steeply over the east flank of the Magdalena Mountains.

However, interpretation of a residual map is ambiguous because the data have been biased, often to an unknown degree, by assumptions regarding "proper" regional trends. Plate 4 shows the expected pattern of gravity lows over valleys and gravity highs over uplands, but further detailed interpretation is not warranted.

Similarly, plate 5 shows a residual magnetic intensity map, whose significance is difficult to assess. There is great relief in the magnetic contours over the northern Magdalena Mountains, but this may have various, non-thermal causes: dipping, and therefore polarized, volcanic units; widespread magnetite, which Laughlin and Koschmann (1942) stated is a very common alteration product in the Magdalena mining district; or relative percentage of magnetite-rich rocks in surface exposures.

Chapin et al. (1978) suggested that aeromagnetic anomalies are subdued along the "transverse shear zone", and they concluded that this is caused by high subsurface temperatures, with the Curie point isotherm occurring at relatively shallow depths. However, it is not easy to agree that the aeromagnetic contours are markedly different along the transverse shear zone or that any special conclusions regarding depth of the Curie point isotherm are warranted. 


\author{
INTERPRETATION OF TEMPERATURE DATA
}

Subsurface temperature data in the Socorro area are relatively abundant, with 32 proprietary and 17 published data points available to this study.

\title{
Temperature
}

Temperatures observed in drill holes in the Socorro area are not exceptionally high: the maximum is $89.6^{\circ} \mathrm{F}\left(32.0^{\circ} \mathrm{C}\right)$ from 1,392 feet $(424 \mathrm{~m}$ ) in hole $B 40$ (plate 6 and table 1). Elevated temperatures are reported for several other holes, including $81.0^{\circ} \mathrm{F}$ $\left(27.2^{\circ} \mathrm{C}\right)$ at 500 feet $(152 \mathrm{~m})$ in $\mathrm{A} 3$ and $80.4^{\circ} \mathrm{F}\left(26.9^{\circ} \mathrm{C}\right)$ at 131 feet $(40 \mathrm{~m})$ in NM2. Many holes in the northern Chupadera Mountains and along Socorro Canyon have temperatures in the range $75-79^{\circ} \mathrm{F}\left(24-27^{\circ} \mathrm{C}\right)$, and the warmest hole also is located in this area.

Temperatures in drill holes in the Nogal Canyon and northern Chupadera Mountains-Socorro Canyon areas are slightly to moderately higher than temperatures observed for nearby groundwater. However, it is discouraging that even in the deepest holes, temperatures are not as high as the warmest groundwater $\left(92^{\circ} \mathrm{F}\right.$ or $33.5^{\circ} \mathrm{C}$ in Socorro and Sedillo Galleries and $103^{\circ} \mathrm{F}$ or $39.4^{\circ} \mathrm{C}$ in well $\$ 367$ ).

Mean annual air temperature is about $57^{\circ} \mathrm{F}\left(14^{\circ} \mathrm{C}\right.$ ) at the elevation of Socorro, and decreases by about $3^{\circ} \mathrm{F}$ per 1,000 feet of elevation $\left(5.5^{\circ} \mathrm{C}\right.$ per $\left.\mathrm{km}\right)$.

\section{Temperature Gradients}

Temperature profiles of most drill holes in the Socorro area are very smooth, with few sharp breaks in gradient or temperature reversals. Many holes have straight-line temperature profiles for intervals longer than $100 \mathrm{~m}$ (330 feet). Characteristic temperature gradients for each hole are given in table 1 and shown on plate 6; the temperature profiles are included in Appendix A.

Regional background temperature gradient can be calculated very approximately for the Socorro area: if the postulated regional magma body at $19 \mathrm{~km}$ has a temperature of $1,200^{\circ} \mathrm{F}\left(650^{\circ} \mathrm{C}\right)$, corresponding to a granitic composition, then the equilibrium conductive 
Table 1. Depths, temperatures, and temperature gradients in the Socorro area, New Mexico

\begin{tabular}{|c|c|c|c|c|}
\hline \multirow{2}{*}{$\begin{array}{c}\text { Hole } \\
\text { Number } \\
\end{array}$} & \multirow[b]{2}{*}{$\begin{array}{c}\text { Depth } \\
\text { (meters) } \\
\end{array}$} & \multirow{2}{*}{$\begin{array}{l}\text { Bottom Hole } \\
\text { Temperature } \\
\left({ }^{\circ} \mathrm{C}\right) \\
\end{array}$} & \multicolumn{2}{|c|}{ Temperature Gradient } \\
\hline & & & $\begin{array}{l}\text { Interval } \\
\text { (meters) } \\
\end{array}$ & $\begin{array}{r}\text { Gradient } \\
\left({ }^{\circ} \mathrm{C} / \mathrm{km}\right) \\
\end{array}$ \\
\hline$B-9$ & 75.9 & 23.00 & $9.1-75.9$ & 71.8 \\
\hline$B-15$ & 79.2 & 22.13 & $12.2-79.2$ & 55.5 \\
\hline$B-19$ & 115.2 & 18.77 & $15.2-115.2$ & 18.6 \\
\hline \multirow[t]{2}{*}{$B-20$} & 73.2 & 25.70 & $9.1-36.6$ & 176.8 \\
\hline & & & $36.6-73.2$ & 37.9 \\
\hline$B-21$ & 116.1 & 16.72 & $18.3-116.1$ & 8.5 \\
\hline$B-22$ & 18.6 & 16.12 & $12.2-18.6$ & 33.9 \\
\hline \multirow[t]{2}{*}{$B-23$} & 91.4 & 18.93 & $9.1-24.4$ & 53.7 \\
\hline & & & $27.4-91.4$ & 41.0 \\
\hline$B-30$ & 128.0 & 22.08 & $27.4-128.0$ & 38.3 \\
\hline \multirow[t]{2}{*}{$B-31$} & 152.4 & 23.95 & $9.1-45.7$ & 20.6 \\
\hline & & & $45.7-152.4$ & 45.4 \\
\hline$B-32$ & 137.2 & 21.55 & $24.4-137.2$ & 31.6 \\
\hline \multirow[t]{2}{*}{$B-33$} & 150.9 & 24.89 & $18.3-42.7$ & 69.9 \\
\hline & & & $42.7-150.9$ & 42.4 \\
\hline \multirow[t]{2}{*}{$B-35$} & 69.2 & 25.37 & $9.1-61.0$ & 128.7 \\
\hline & & & $64.0-69.2$ & -26.7 \\
\hline \multirow[t]{6}{*}{$B-40$} & 424.4 & 32.02 & $15.2-61.0$ & 71.4 \\
\hline & & & $61.0-122.0$ & 23.3 \\
\hline & & & $122.0-167.7$ & 9.1 \\
\hline & & & $167.7-274.4$ & 33.1 \\
\hline & & & $274.4-396.3$ & 19.2 \\
\hline & & & $396.3-424.4$ & 5.9 \\
\hline$F-1$ & 97.6 & 19.84 & $18.3-97.6$ & 40.1 \\
\hline \multirow[t]{2}{*}{$F-3$} & 87.2 & 17.66 & $12.2-48.8$ & 47.0 \\
\hline & & & $48.8-87.2$ & 25.2 \\
\hline \multirow[t]{2}{*}{$F-4$} & 96.0 & 17.13 & $12.2-24.4$ & 55.1 \\
\hline & & & $24.4-96.0$ & 22.2 \\
\hline \multirow[t]{3}{*}{$\mathrm{U}-3$} & 152.4 & 25.87 & $15.2-42.7$ & 41.0 \\
\hline & & & $45.7-140.2$ & 42.1 \\
\hline & & & $140.2-152.4$ & -10.0 \\
\hline
\end{tabular}


Table 1 (continued)

\begin{tabular}{|c|c|c|c|c|}
\hline \multirow{3}{*}{$\begin{array}{l}\text { Hole } \\
\text { Number }\end{array}$} & \multirow[b]{3}{*}{$\begin{array}{c}\text { Depth } \\
\text { (meters) }\end{array}$} & \multirow{3}{*}{$\begin{array}{l}\text { Bottom Hole } \\
\text { Temperature } \\
\left({ }^{\circ} \mathrm{C}\right) \\
\end{array}$} & \multicolumn{2}{|c|}{ Characteristic } \\
\hline & & & Temperatur & \\
\hline & & & $\begin{array}{l}\text { Interval } \\
\text { (meters) }\end{array}$ & $\begin{array}{r}\text { Gradient } \\
\left({ }^{\circ} \mathrm{C} / \mathrm{km}\right)\end{array}$ \\
\hline$U-4$ & 114.6 & 25.37 & $18.3-114.6$ & 45.2 \\
\hline \multirow[t]{2}{*}{ SIB } & 153.6 & 22.76 & $12.2-67.1$ & 18.8 \\
\hline & & & $67.1-152.4$ & 21.9 \\
\hline$S 2 B$ & 146.3 & 23.29 & $18 \cdot 3-146.3$ & 50.0 \\
\hline s3 & 150.3 & 20.09 & $12.2-150.3$ & 29.0 \\
\hline \multirow[t]{2}{*}{54} & 152.1 & 20.16 & $18.3-85.3$ & 23.4 \\
\hline & & & $85.3-152.1$ & 34.1 \\
\hline S5 & 153.7 & 18.16 & $18.3-153.6$ & 14.5 \\
\hline \multirow[t]{2}{*}{57} & 151.2 & 20.05 & $12.2-88.4$ & 24.5 \\
\hline & . & & $88.4-151.2$ & 29.4 \\
\hline s8 & 146.6 & 22.61 & $18.3-146.6$ & 43.7 \\
\hline \multirow[t]{2}{*}{ S9B } & 152.4 & 24.16 & $12.2-36.6$ & 63.3 \\
\hline & & & $36.6-149.3$ & 44.4 \\
\hline$A 1 B$ & 146.3 & 25.05 & $12.2-146.3$ & 49.0 \\
\hline $\mathrm{A} 2 \mathrm{~B}$ & 152.4 & 23.01 & $12.2-152.4$ & 31.7 \\
\hline \multirow[t]{4}{*}{ A3 } & 152.4 & 27.23 & $12.2-61.0$ & 95.4 \\
\hline & & & $61.0-91.4$ & 68.2 \\
\hline & & & $91.4-121.9$ & 41.2 \\
\hline & & & $121.9-152.4$ & 14.0 \\
\hline \multirow[t]{3}{*}{ A4 } & 140.2 & 20.25 & $12.2-42.7$ & -4.2 \\
\hline & & & $42.7-97.5$ & 22.5 \\
\hline & & & $97.5-140.2$ & 29.0 \\
\hline \multirow[t]{2}{*}{ A5 } & 151.5 & 20.15 & $12.2-103.6$ & 19.8 \\
\hline & & & $103.6-151.5$ & 30.1 \\
\hline $\mathrm{A} 6 \mathrm{~B}$ & 140.2 & 22.27 & $12.2-140.2$ & 39.2 \\
\hline NMI & 61.0 & - & $6.0-31.0$ & 155.9 \\
\hline \multirow[t]{2}{*}{ NM2 } & 40.0 & - & $11.0-21.0$ & 240.9 \\
\hline & & & $25.0-40.0$ & 159.0 \\
\hline \multirow[t]{2}{*}{ NM3 } & 70.0 & - & $10.0-20.0$ & 119.0 \\
\hline & & & $35.0-70.0$ & 35.5 \\
\hline
\end{tabular}


Table 1 (continued)

\begin{tabular}{|c|c|c|c|c|}
\hline \multirow[b]{2}{*}{$\begin{array}{l}\text { Hole } \\
\text { Number }\end{array}$} & \multirow[b]{2}{*}{$\begin{array}{l}\text { Depth } \\
\text { (meters) }\end{array}$} & \multirow{2}{*}{$\begin{array}{c}\text { Bottom Hole } \\
\text { Temperature } \\
\left({ }^{\circ} \mathrm{C}\right)\end{array}$} & \multicolumn{2}{|c|}{ Characteristic } \\
\hline & & & $\begin{array}{l}\text { Interval } \\
\text { (meters) }\end{array}$ & $\begin{array}{l}\text { Gradient } \\
\left({ }^{\circ} \mathrm{C} / \mathrm{km}\right)\end{array}$ \\
\hline \multirow[t]{4}{*}{$\mathrm{NM} 4$} & 100.0 & - & $10.0-20.0$ & 98.2 \\
\hline & & & $25.0-35.0$ & 39.2 \\
\hline & & & $40.0-60.0$ & 19.3 \\
\hline & & & $70.0-100.0$ & 24.3 \\
\hline \multirow[t]{3}{*}{ NM5 } & 110.0 & - & $10.0-20.0$ & 83.7 \\
\hline & & & $25.0-60.0$ & 45.6 \\
\hline & & & $90.0-110.0$ & 50.1 \\
\hline NM6 & 20.0 & 19.1 & $10.0-20.0$ & 96.2 \\
\hline NM7 & 20.0 & 18.4 & $10.0-20.0$ & 93.9 \\
\hline \multirow[t]{2}{*}{ NM8 } & 25.0 & - & $10.0-20.0$ & 96.9 \\
\hline & & & $20.0-25.0$ & 44.4 \\
\hline \multirow[t]{2}{*}{ NM9 } & 35.0 & - & $10.0-20.0$ & 97.9 \\
\hline & & & $25.0-35.0$ & 28.0 \\
\hline \multirow[t]{2}{*}{ NM10 } & 30.0 & 16.2 & $10.0-20.0$ & 107.0 \\
\hline & & & $20.0-30.0$ & 73.0 \\
\hline \multirow[t]{3}{*}{ NM11 } & 80.0 & - & $30.0-40.0$ & 44.2 \\
\hline & & & $40.0-50.0$ & 20.7 \\
\hline & & & $50.0-80.0$ & 10.2 \\
\hline $\mathrm{X} 1$ & 76.0 & - & $15.0-76.0$ & 54.7 \\
\hline $\mathrm{X} 2$ & 70.0 & - & $35.0-70.0$ & 35.5 \\
\hline $\mathrm{X} 3$ & 58.0 & - & $21.0-58.0$ & 33.8 \\
\hline$x 4$ & 40.0 & - & $12.0-40.0$ & 161.9 \\
\hline$\times 5$ & 31.0 & - & $12.0-31.0$ & 168.2 \\
\hline $\mathrm{X} 6$ & 64.0 & - & $34.0-64.0$ & 149.5 \\
\hline
\end{tabular}


temperature gradient would be $1.8^{\circ} \mathrm{F} / 100 \mathrm{ft}\left(33^{\circ} \mathrm{C} / \mathrm{km}\right)$. If the temperature of the magma body is $1,850^{\circ} \mathrm{F}\left(1,000^{\circ} \mathrm{C}\right)$, corresponding to basaltic composition, then the equilibrium temperature gradient would be $2.9^{\circ} \mathrm{F} / 100 \mathrm{ft}\left(52^{\circ} \mathrm{C} / \mathrm{km}\right)$. In this report, the conservative value of $1.7^{\circ} \mathrm{F} / 100 \mathrm{ft}\left(30^{\circ} \mathrm{C} / \mathrm{km}\right)$ is used to represent regional background conductive heat transfer conditions; gradients must exceed $3.0^{\circ} \mathrm{F} / 100 \mathrm{ft}\left(54^{\circ} \mathrm{C} / \mathrm{km}\right)$ to be considered abnormal.

Anomalously high temperature gradients to moderate depths are reported for holes $B 9, B 15$, and $X 6$, whose gradients are 4.0 , 3.1 , and $8.3^{\circ} \mathrm{F} / 100 \mathrm{ft}\left(71.8,55.5\right.$, and $\left.149.5^{\circ} \mathrm{C} / \mathrm{km}\right)$, respectively. These holes range from 210 to 260 feet $(64$ to $79 \mathrm{~m})$ deep, and the gradients are reported from far below the zone of influence of seasonal variation. Bottom-hole temperatures of $B 9$ and $B 15$ are not high $\left(72-74^{\circ} \mathrm{F}\right.$, or $\left.22-23^{\circ} \mathrm{C}\right)$; therefore, these results may indicate largely conductive heat transfer conditions. Unfortunately, no heat flow data are available for these holes. No bottom-hole temperature is available for X6, but the setting of this hole leads one to suspect that the very high temperature gradient represents conductive heat transfer over a warm-water aquifer.

Values in excess of $2.75^{\circ} \mathrm{F} / 100 \mathrm{ft}\left(50^{\circ} \mathrm{C} / \mathrm{km}\right)$ are reported for shallow levels ( 100 feet or $30 \mathrm{~m}$, or less) of many drill holes in the northeast part of the project area; however, these holes terminate at these shallow depths and it is unknown whether high gradients persist.

In the Chupadera Mountains, very high gradients are reported at sha1low levels in B35, A3, and B40 $\left(7.1,5.3\right.$, and $3.9^{\circ} \mathrm{F} / 100 \mathrm{ft}$, or $128.7,95.4$, and $71.4^{\circ} \mathrm{C} / \mathrm{km}$, respectively). That each of these holes is influenced by convective heat transfer is shown by the isothermal or even reversed $\left(-1.5^{\circ} \mathrm{F} / 100 \mathrm{ft}\right.$, or $-26.7^{\circ} \mathrm{C} / \mathrm{km}$ at the bottom of B35) temperature profiles at deeper levels.

Most temperature gradients in the Socorro area change very little with depth, and most values are subaverage to only slightly above average. The La Jencia Creek-Socorro Canyon topographic low is characterized by very low temperature gradients to considerable depth (note especially B21, F4, and B19). Of the 18 points which go as deep as $500 \mathrm{ft}(150 \mathrm{~m})$, only 2 (A4 and A5) have higher gradients at $500 \mathrm{ft}(150 \mathrm{~m})$ than at $330 \mathrm{ft}(100 \mathrm{~m}) ; 3$ points (A3, B40, and U3) have lower values at $500 \mathrm{ft}(150 \mathrm{~m})$. The highest gradient reported at either depth is $2.8^{\circ} \mathrm{F} / 100 \mathrm{ft}\left(50^{\circ} \mathrm{C} / \mathrm{km}\right)$ for hole $\mathrm{S} 2 \mathrm{~B}$. NM5 also reported $2.8^{\circ} \mathrm{F} / 100 \mathrm{ft}\left(50^{\circ} \mathrm{C} / \mathrm{km}\right)$ for the interval $295-360$ ft $(90-110 \mathrm{~m})$; and $A 1 B$ showed $2.7^{\circ} \mathrm{F} / 100 \mathrm{ft}\left(49^{\circ} \mathrm{C} / \mathrm{km}\right)$ over its entire range of depth to $480 \mathrm{ft}$ (146 m). 
Several of the deeper holes show gradients of approximately $2.2-2.5^{\circ} \mathrm{F} / 100 \mathrm{ft}\left(40-45^{\circ} \mathrm{C} / \mathrm{km}\right)$. These are $\mathrm{A} 6 \mathrm{~B}, \mathrm{~B} 31, \mathrm{~B} 33, \mathrm{~S} 8$, and $\mathrm{S} 9 \mathrm{~B}$. These values may be representative of the regional gradient in diverse rocks of younger sedimentary and volcanic provenance. If such gradients are projected to 10,000 feet $(3 \mathrm{~km})$, at which depth holes probably would be in massive crystalline rock (Precambrian basement or Tertiary intrusive), such temperatures would only be $275-300^{\circ} \mathrm{F}\left(135-150^{\circ} \mathrm{C}\right)$. Such temperatures are unattractive for geothermal exploration.

The temperature profile of the deepest hole, B40, is very illuminating. Gradients at the top of the hole are fairly high, but an isothermal zone $\left(78^{\circ} \mathrm{F}\right.$ or $\left.25.5^{\circ} \mathrm{C}\right)$ at $400-550$ feet $(122-168 \mathrm{~m})$ represents a warm-water aquifer. Lower in the hole, conductive heat transfer conditions are shown by a straight-line temperature profile and moderate gradients, but another deep warm-water aquifer is represented by another isothermal section $\left(90^{\circ} \mathrm{F}\right.$ or $\left.32.0^{\circ} \mathrm{C}\right)$ at $1,300-$ 1,391 feet $(396-424 \mathrm{~m})$.

These relations show that deep water circulation is occurring in the northern Chupadera Mountains, and that high near-surface gradients can be caused by very moderate temperatures at depth. Whether low to moderate gradients in the zone to 500 feet ( $150 \mathrm{~m}$ ) can be caused by cool groundwater masking or washing out deeper thermal features is discussed in subsequent sections.

\section{Heat Flow}

Computations

Calculated heat flow values for 32 holes in the Socorro area, including one 1,391 feet $(424 \mathrm{~m})$ deep, are given in table 2 and shown on plate 7. Two published data points also are shown on plate 7. These heat flow computations were made using a range of likely porosities and assuming water-saturated conditions throughtout. The resulting range of heat flow values takes into account the fact that in situ porosities in poorly consolidated sedimentary rocks cannot be measured directly, and usually cannot be estimated closely from drill cuttings. Calculations that assume high porosities yield lower heat flow values than do low porosities, because the thermal conductivity of water is 1.381 thermal conductivity units $\left(10^{-3} \mathrm{cal} / \mathrm{cm}-\mathrm{sec}^{\circ}{ }^{\circ} \mathrm{C}\right)$, whereas the measured thermal conductivity of the rock material ranges from 3.32 to $6.39 \mathrm{TCU}$. For the data of this study, the difference between high and low porosities generally is $0.5 \mathrm{HFU}$ or less. 
Table 2. Heat flow in the Socorro area, New Mexico

\begin{tabular}{|c|c|c|c|c|c|c|c|c|}
\hline $\begin{array}{c}\text { Hole } \\
\text { Number } \\
\end{array}$ & $\begin{array}{l}\text { Depth } \\
\text { Interval, } \\
\text { meters } \\
\end{array}$ & $\begin{array}{l}\text { Terrain } \\
\text { Correc- } \\
\text { tion; \% } \\
\end{array}$ & $\begin{array}{c}\text { Tempera- } \\
\text { ture } \\
\text { Gradient } \\
{ }^{\circ} \mathrm{C} / \mathrm{km} \\
\end{array}$ & $\begin{array}{l}\text { Thermal } \\
\text { Conduc } \bar{I} \\
\text { tivity } \\
\end{array}$ & $\begin{array}{c}\text { Range of } \\
\text { porosities } \\
\text { estimated } \\
\text { for } \\
\text { interval; \% }\end{array}$ & $\begin{array}{l}\text { Range of } \\
\text { heat flow, } \\
\text { minimum } \\
\text { porosity }\end{array}$ & $\begin{array}{l}\text { mputed } \\
\text { in HFU } \\
\text { maximum } \\
\text { porosity }\end{array}$ & \\
\hline B9 & $9-75$ & -5 & 71.8 & $4.0^{3}$ & $20-40$ & 2.22 & 1.80 & \\
\hline B15 & $12-79$ & 0 & 55.5 & $4.6^{3}$ & $20-40$ & 2.01 & 1.58 & \\
\hline B19 & $15-115$ & 0 & 18.6 & $4.8^{3}$ & $20-40$ & 0.70 & 0.55 & \\
\hline B20 & $39-73$ & 0 & 37.9 & $3.9^{3}$ & $5-20$ & 1.41 & 1.20 & \\
\hline B21 & $18-116$ & 0 & 8.5 & $5.2^{3}$ & $20-40$ & 0.34 & 0.26 & \\
\hline $\mathrm{B} 22$ & $12-19$ & 0 & 33.9 & $4.3^{3}$ & $20-40$ & 1.17 & 0.93 & \\
\hline B23 & $27-91$ & 0 & 41.0 & $4.1^{3}$ & $20-40$ & 1.36 & 1.10 & \\
\hline B30 & $33-125$ & 0 & 38.3 & $5.0^{3}$ & $5-20$ & 1.81 & 1.48 & \\
\hline B31 & $46-152$ & 0 & 45.4 & $4.7^{3}$ & $20-40$ & 1.68 & 1.32 & \\
\hline B32 & $33-137$ & 0 & 31.6 & $5.5^{3}$ & $5-40^{4}$ & 1.63 & 1.01 & \\
\hline B33 & $43-137$ & 0 & .42 .4 & $4.6^{3}$ & $20-40$ & 1.54 & 1.21 & \\
\hline B35 & $24-61$ & 0 & 128.7 & $4.4^{3}$ & $5-40^{4}$ & 5.38 & 3.59 & \\
\hline \multirow[t]{2}{*}{ B40 } & $168-274$ & 0 & 33.1 & $6.0^{5}$ & $5-20$ & 1.86 & 1.49 & \\
\hline & $274-396$ & 0 & 19.2 & $6.0^{3}$ & $5-40^{4}$ & 1.08 & 0.64 & \\
\hline$F 1$ & $18-98$ & 0 & 40.1 & $6.2^{3}$ & $20-40$ & 1.85 & 1.37 & \\
\hline F3 & $49-85$ & 0 & 25.2 & $5.1^{3}$ & $20-40$ & 1.00 & 0.77 & \\
\hline F4 & $24-96$ & 0 & 22.2 & $5.5^{3}$ & $20-40$ & 0.93 & 0.71 & \\
\hline U3 & $15-137$ & 0 & 41.5 & $4.6^{3}$ & $5-40^{6}$ & 1.81 & 1.19 & \\
\hline U4 & $33-113$ & 0 & 45.2 & 4.3 & $5-40^{6}$ & 1.85 & 1.24 & \\
\hline \multirow[t]{3}{*}{ SIB } & $24-49$ & -10 & 19.0 & 5.34 & $20-40$ & 0.70 & 0.53 & \\
\hline & $91-98$ & -5 & 22.1 & 3.72 & $20-40$ & \multirow{2}{*}{$0.70^{7}$} & $0.52)$ & \\
\hline & $134-140$ & 0 & 22.1 & 4.36 & $20-40$ & & $0.61\}$ & \\
\hline \multirow[t]{3}{*}{$S 2 B$} & $49-79$ & -5 & 50.3 & 5.48 & $20-40$ & \multirow{2}{*}{$2.18^{7}$} & $1.51\}$ & \\
\hline & $79-110$ & 0 & 50.3 & 6.39 & $20-40$ & & $1.74)$ & \\
\hline & $140-146$ & 0 & 50.3 & 3.79 & $1-10$ & 1.89 & 1.72 & \\
\hline \multirow[t]{3}{*}{ S3 } & $12-79$ & 0 & 29.2 & 4.67 & $20-40$ & \multirow{2}{*}{$1.09^{7}$} & $0.84\}$ & \\
\hline & $79-85$ & 0 & 29.2 & 4.52 & $20-40$ & & $0.82\}$ & 0.85 \\
\hline & $122-146$ & 0 & 29.2 & 5.14 & $20-40$ & $1.15\}$ & $0.89\}$ & \\
\hline \multirow[t]{3}{*}{ S4 } & $43-85$ & 0 & 23.5 & 5.75 & $20-40$ & 1.02 & 0.76 & \\
\hline & $91-140$ & 0 & 34.3 & 5.28 & $20-40$ & $1.45^{7}$ & $1.06)$ & \\
\hline & $140-152$ & 0 & 34.3 & 6.01 & $20-40$ & $1.53)$ & 1.145 & \\
\hline
\end{tabular}


Table 2 (continued)

\begin{tabular}{|c|c|c|c|c|c|c|c|}
\hline $\begin{array}{c}\text { Hole } \\
\text { Number }\end{array}$ & $\begin{array}{l}\text { Depth } \\
\text { Interval, } \\
\text { meters } \\
\end{array}$ & $\begin{array}{l}\text { Terrain } \\
\text { Correc- } \\
\text { tion; \% } \\
\end{array}$ & $\begin{array}{c}\text { Tempera- } \\
\text { ture } \\
\text { Gradient } \\
{ }^{\circ} \mathrm{C} / \mathrm{km} \\
\end{array}$ & $\begin{array}{l}\text { Thermal } \\
\text { Conduc } \overline{1} \\
\text { tivity } \\
\end{array}$ & $\begin{array}{l}\text { porosities } \\
\text { estimated } \\
\text { for } \\
\text { interval; \% } \\
\end{array}$ & $\begin{array}{l}\text { Range of } \\
\text { heat flow, } \\
\text { minimum } \\
\text { porosity }\end{array}$ & $\begin{array}{l}\text { inputed } \mathrm{HFU}^{2} \\
\text { maximum } \\
\text { porosity }\end{array}$ \\
\hline S5 & $67-91$ & 0 & 14.6 & 4.12 & $20-40$ & 0.48 & 0.39 \\
\hline \multirow{2}{*}{57} & $24-79$ & 0 & 24.6 & 5.28 & $20-40$ & 0.99 & 0.76 \\
\hline & $104-152$ & 0 & 29.5 & 5.33 & $20-40$ & 1.20 & 0.92 \\
\hline S8 & $30-146$ & 0 & 43.9 & 4.80 & $20-40$ & 1.64 & 1.28 \\
\hline \multirow[t]{3}{*}{$S 9 B$} & $30-37$ & -5 & 63.6 & 4.31 & $20-40$ & 2.07 & 1.65 \\
\hline & $98-116$ & 0 & 44.7 & 5.49 & $20-40$ & \multirow{2}{*}{$1.90^{7}$} & 1.41) \\
\hline & $134-146$ & 0 & 44.7 & 5.73 & $20-40$ & & $1.45)$ \\
\hline \multirow[t]{2}{*}{$A 1 B$} & $37-91$ & -5 & 49.2 & 4.56 & $20-40$ & \multirow{2}{*}{$1.62^{7}$} & $1.32\}$ \\
\hline & $91-146$ & 0 & 49.2 & 3.93 & $20-40$ & & $1.27)$ \\
\hline \multirow[t]{3}{*}{$\mathrm{A} 2 \mathrm{~B}$} & $24-30$ & 0 & 31.9 & 5.15 & $20-40$ & \multirow{2}{*}{$1.13^{7}$} & \multirow{2}{*}{$\left.\begin{array}{l}0.97\} \\
0.88\end{array}\right\}$} \\
\hline & $98-110$ & 0 & 31.9 & 4.34 & $20-40$ & & \\
\hline & $128-140$ & 0 & 31.9 & 3.94 & $20-40$ & 1.02 & 0.83 \\
\hline \multirow[t]{4}{*}{ A3 } & $37-61$ & 0 & 95.9 & 4.33 & $20-40$ & 3.30 & 2.63 \\
\hline & $61-91$ & 0 & 68.5 & 4.78 & $20-40$ & 2.56 & 1.99 \\
\hline & $91-110$ & 0 & 41.4 & 4.12 & $20-40$ & 1.37 & 1.10 \\
\hline & $122-140$ & 0 & 14.0 & 3.97 & $20-40$ & 0.45 & 0.37 \\
\hline \multirow[t]{3}{*}{ A4 } & $55-98$ & 0 & 22.6 & 4.69 & $20-40$ & 0.83 & 0.65 \\
\hline & $110-116$ & 0 & 29.2 & 4.06 & $20-40$ & \multirow{2}{*}{$0.94^{7}$} & 0.773 \\
\hline & $134-146$ & 0 & 29.2 & 3.93 & $20-40$ & & $0.75)$ \\
\hline \multirow[t]{2}{*}{ A.5 } & $37-55$ & 0 & 19.9 & 5.69 & $20-40$ & 0.85 & 0.64 \\
\hline & $134-140$ & 0 & 30.3 & 4.61 & $20-40$ & 1.10 & 0.86 \\
\hline \multirow[t]{2}{*}{$A 6 B$} & $31-85$ & 0 & 39.4 & 3.32 & $20-40$ & \multirow{2}{*}{$.1 .7^{7}$} & $0.92\}$ \\
\hline & $116-140$ & 0 & 39.4 & 3.89 & $20-40$ & & $1.01)$ \\
\hline
\end{tabular}

${ }^{1} 10^{-3} \mathrm{cal} / \mathrm{cm}^{\circ} \mathrm{C}-\mathrm{sec}$

$20^{-6} \mathrm{cal} / \mathrm{cm}^{2}-\mathrm{sec}$

3 Averaged value for several samples in interval. Lithology of samples not given.

${ }^{4}$ Wide range of porosities used because it is not known which of several widely

differing 1ithologies was used for thermal conductivity measurements.

${ }^{5}$ Assumed value; not measured.

${ }^{6}$ Wide range of porosities used because lithology is not known.

7 Averaged over segment of constant temperature gradient and similar lithology. 
Topographic factors have been difficult to calculate for this suite of holes. Although most holes are at lower elevations and on gentler slopes than the Socorro Peak upland, these gentler slopes in turn are an upland plateau above the Rio Grande flood plain. The town of Socorro, 4 miles east of Socorro Peak, is at 4,600 feet. The upper reaches of Socorro Canyon near S9B are at about 5,500 feet. Most of the Socorro Peak block is over 6,000 feet in elevation, locally reaching over 7,000 feet. These topographic relations are highlighted on plate 8 . The resultant asymmetric topography exhibits over 2,000 feet on the east slope of Socorro Peak, but only 1,200 feet maximum on the western slope.

Therefore, each hole location has both a local and a regional topographic setting, and is affected by both higher-elevation uplands and the deep valley of the Rio Grande. After several attempts, a set of terrain corrections was developed to take both factors into account. Net effect is nearly zero in almost every case. Where there is a terrain correction, it is reduced to zero by $150 \mathrm{~m}$ in depth.

\section{Regional Heat Flow}

According to Reiter et al. (1975), regional background heat flow in the Socorro area under conductive heat transfer conditions may be $2.5 \mathrm{HFU}$ or greater. Their regional heat flow map is given here as figure 5; it shows five control points within the project area. Detailed data on four of these points (table 3 ) show that calculated heat flow values of 1.9-2.5 HFU are reported for deep holes with relatively well-known rock porosities and thermal conductivities.

However, the fifth control point in the project area is given as greater than $3.0 \mathrm{HFU}$ (figure 5), although no reference is indicated and no detailed supporting data are given. From its position, this point probably represents two heat flow values of 11.7 and $9.6 \mathrm{HFU}$, which later were reported by Reiter and Smith (1977) for the east side of Socorro Peak (shown on plate 7 as NMI and NM2).

As is discussed in the section on Water Chemistry, the east side of Socorro Peak is characterized by circulation of moderately warm groundwater. This, plus the relatively shallow depths reported for NM1 and NM2, lead one to suspect that the high heat flows represent only shallow conductive heat transfer above a moderatetemperature convective system. 


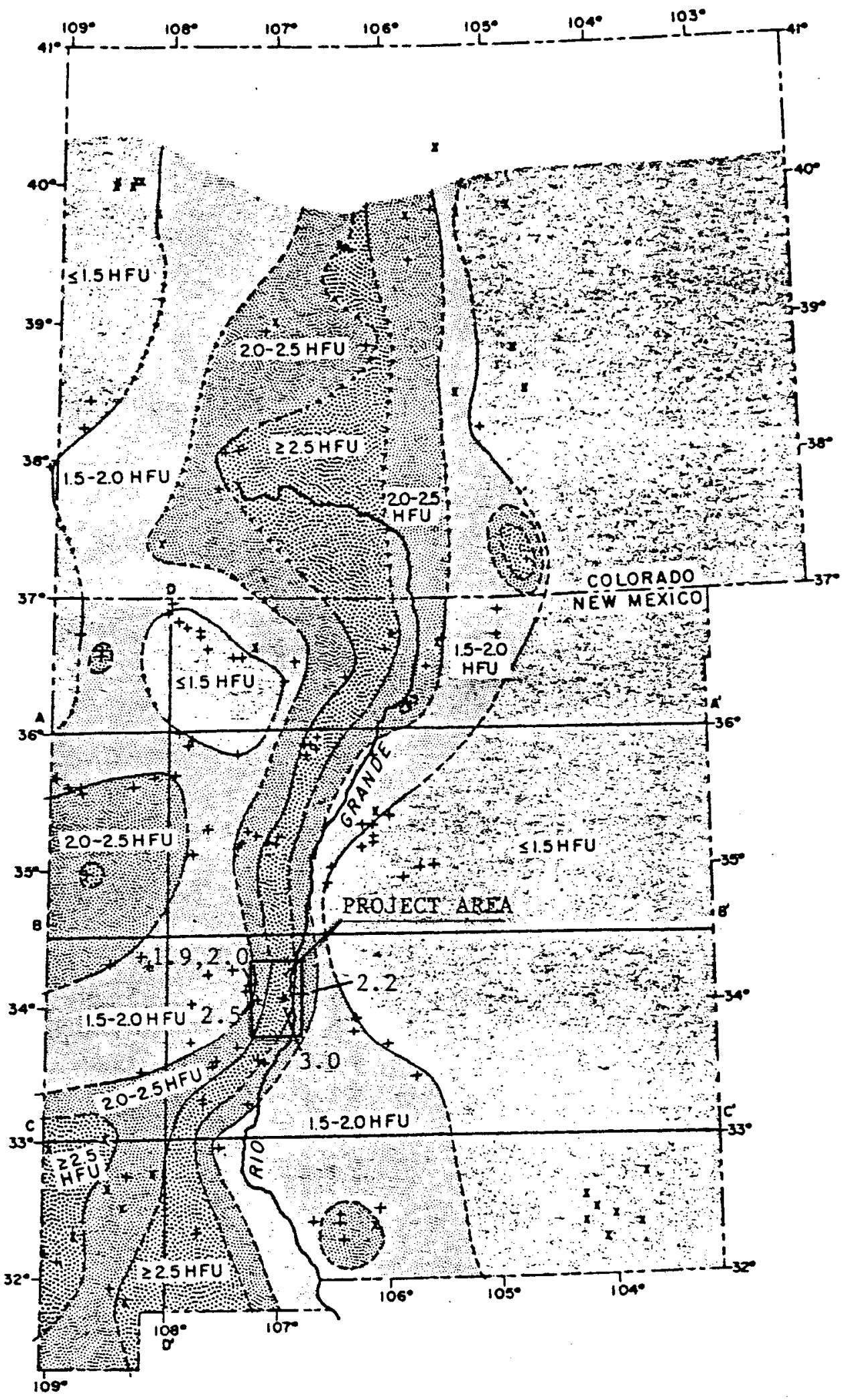

FIGURE 5. Terrestrial heat-flow contour map of New Mexico and southern Colorado. Contour interval, $0.5 \mathrm{HFU}$. Plus signs indicate control sites measured by New Mexico Institute of Mining and Technology; X's indicate control sites of other investigators. (From Reiter et al., 1975). 
Table 3. Heat flow data for control points in the Socorro area, New Mexico (after Reiter et al., 1975)

\begin{tabular}{|c|c|c|c|c|c|c|c|c|}
\hline Locality & North Lat & West Long & $\begin{array}{c}\text { Depth } \\
\text { Interval } \\
\text { (meters) } \\
\end{array}$ & $\begin{array}{c}\text { Temperature } \\
\text { Gradient, } \\
{ }^{\circ} \mathrm{C} / \mathrm{km} \\
\end{array}$ & $\begin{array}{c}\text { Thermal } \\
\text { Conductivity } \\
\text { (TCU) }\end{array}$ & $\begin{array}{r}\text { Type of } \\
\text { Sample } \\
\end{array}$ & $\begin{array}{l}\text { Calculated } \\
\text { Heat Flow }\end{array}$ & $\begin{array}{l}\text { Best } \\
\text { Heat Flow } \\
\text { Estimate }\end{array}$ \\
\hline \multirow[t]{2}{*}{ Chupadera Mesa } & $34^{\circ} 06^{\prime}$ & $106^{\circ} 48^{\prime}$ & $70-130$ & 33.47 & 6.69 & Fragments & 2.24 & \multirow{2}{*}{2.20} \\
\hline & & & $130-160$ & 42.61 & 5.06 & Fragments & 2.16 & \\
\hline \multirow[t]{2}{*}{ Magdalena/NW } & $34^{\circ} 09^{\prime}$ & $107^{\circ} 18^{\prime}$ & $90-1.90$ & 43.99 & 4.31 & Core & 1.90 & \multirow{2}{*}{1.91} \\
\hline & & & $170-300$ & 40.44 & 4.73 & Core & 1.91 & \\
\hline Magdalena/West & $34^{\circ} 07^{\prime}$ & $107^{\circ} 17^{\prime}$ & $120-180$ & 38.93 & 5.17 & Core & 2.01 & 2.01 \\
\hline \multirow[t]{2}{*}{ North Baldy } & $34^{\circ} 02^{\prime}$ & $107^{\circ} 13^{\prime}$ & $150-210$ & 33.86 & 5.86 & Core & 1.98 & \multirow[t]{2}{*}{2.48} \\
\hline & & & $230-280$ & 44.69 & 6.66 & Core & 2.98 & \\
\hline
\end{tabular}


JAMES B. KOENIG (415) 524-9242

MURRAY C. GARDNER (503) $482-2605$

Heat flow values in excess of 2.5 HFU have not been demonstrated for conductive heat transfer conditions in deeper holes in the central part of the Rio Grande rift near Socorro. Instead, background conductive heat flow of 2.0-2.5 HFU seems more likely, and undisturbed values of 1.5-2.0 HFU may be encountered locally.

\section{Discussion}

The highest heat flow values reported from the Socorro area are 11.7 and $9.6 \mathrm{HFU}$ from NMI and NM2, 3.6-5.4 HFU (maximum and minimum porosity values) from B35, 2.6-3.3 HFU from the top of $A 3$, 1.6-2.1 HFU from the top of $\mathrm{S} 9 \mathrm{~B}$, and 1.5-1.9 HFU from the top of $B 40$. However, each of these values is disturbed by convective groundwater flow, and does not represent conductive heat transfer conditions. That this is so for $A 3$ and $B 40$ is shown by the decline in heat flow computed for deeper levels (plate 7). Hole B35 has a reversed temperature profile below the interval used in the heat flow computation, which demonstrates groundwater circulation.

Subaverage (less than $2.0 \mathrm{HFU}$ ) heat flow values are computed for all other temperature gradient holes in the Socorro area. Many of the values are lower than $1.5 \mathrm{HFU}$, which cannot represent background conductive heat flow in this region, but rather demonstrates large-scale disturbance by groundwater convection. Most notable are F3, F4, B21, S5, S3, S1B, S7, B22, A5, and B19. These holes are located in an area thought to be affected by groundwater mixing, based on hydrologic and geochemical evidence (see Water Chemistry). That the low heat flows and postulated groundwater movement are not shallow phenomena is shown by the smooth temperature profiles and very low heat flows computed to depths of 280 feet $(85 \mathrm{~m})$ or greater, especially in F3, F4, B21, S5, and B19.

Deep circulation of moderate temperature groundwater is demonstrated in B40 in the northern Chupadera Mountains. Here, the bottom-hole temperature is only $90^{\circ} \mathrm{F}\left(32.0^{\circ} \mathrm{C}\right)$ at 1,391 feet $(424 \mathrm{~m})$ and the heat flow computed near the bottom of the hole is only 0.6$1.1 \mathrm{HFU}$.

In summary, regional background heat flow in the Socorro area probably is closer to 2.0 than to $2.5 \mathrm{HFU}$; and the hypothesis of undisturbed conductive heat flow in excess of $2.5 \mathrm{HFU}$ is unproven. Most of the heat flow values computed for temperature gradient holes in the area are subaverage $(1.0-2.0 \mathrm{HFU})$ and many values are so low 
JAMES B. KOENIG (415) 524-9242

MURRAY C. GARDNER (503) 482-2605

(1ess than $1.0 \mathrm{HFU}$ ) that they demonstrate large-scale groundwater circulation of moderate temperature, which is in accord with evidence of groundwater mixing developed independently from hydrologic and geochemical data. Six points have computed heat flow greater than $2.0 \mathrm{HFU}$ (maximum $11.7 \mathrm{HFU}$ ), but heat transfer by groundwater convection is essentially proven at four of these points and is very likely at the two with the highest computed heat flow. Deep (to 1,391 feet or $424 \mathrm{~m}$ ) groundwater circulation of moderate temperature $\left(32.0^{\circ} \mathrm{C}\right)$ water is observed in the northern Chupadera Mountains from temperature gradient and heat-flow data.

Overall, the heat flow data do not indicate a strong geothermal system in the Socorro area. If a strong heat source exists, it is masked by circulating cool groundwater at moderate depth.

\section{GROUND WATER}

A large number of chemical analyses, water temperatures, and determinations of depth to ground water are available for the project area (plate 8). These were compiled from published data (Clark and Summers, 1971; Summers et al., 1972; Summers, 1976) and appear to be relatively complete, in that most springs, windmills, and water wells noted on topographic maps are represented by at least partial data. Because the land on the lower slopes of the Magdalena Mountains and in the La Jencia Creek-Socorro Canyon area is used primarily for grazing, there are not thought to be many unrepresented irrigation or other water wells.

The well depths reported on plate 8 range from $12 \mathrm{~m}$ (for 非91) to $564 \mathrm{~m}$ (for 非82), with the average depth about $50 \mathrm{~m}$.

Water levels are shown on plate 8 as elevation relative to sea leve1, and are assumed to have been measured inside the completed well. In each measurement, it is not known if shallow aquifers were cased off, and the water table is therefore somewhat higher than reported; or if there is much artesian head difference that elevates the measured water surface above the inflow zone. However, the reported water-surface depths made a consistent pattern, so these factors do not appear to be important.

Water-surface measurements were made between 1962 and 1967. Some were made in April, but most were made in June, July, or August, and should represent comparable seasonal recharge-drawdown conditions. 
No long-term changes in groundwater levels are known to affect the area.

\section{Recharge}

The amount of water annually available for recharge to the groundwater system in the La Jencia Creek-Socorro Canyon area can be estimated loosely from figures 6 and 7 and data on precipitation given in Summers et al. (1972). Only order-of-magnitude estimates can be made, since available information is insufficient regarding vegetation patterns and evapotranspiration rates.

Arid conditions in the project area are depicted in figure 6, which shows the annual precipitation in the Socorro region generally to be less than $12 \mathrm{in} / \mathrm{yr}(30.5 \mathrm{~cm} / \mathrm{yr})$, except in high mountainous areas. Summers et al. (1972) gave details of the higher precipitation rates for the Magdalena Mountains, with $13.4 \mathrm{in} / \mathrm{yr}$ (34 cm/yr) measured at 7,000 feet $(2,400 \mathrm{~m})$ and $17.7 \mathrm{in} / \mathrm{yr}(45 \mathrm{~cm} / \mathrm{yr})$ at the crest $(10,630$ feet or $3,240 \mathrm{~m})$.

Figure 7 shows the surface drainage basin of the project area, including La Jencia Creek above La Jencia Ranch, Nogal Canyon on the west side of the Socorro Peak block, and Socorro Canyon west of Box Canyon in Sec. 31, T. $3 \mathrm{~S} ., \mathrm{R} .1 \mathrm{~W}$. The areas were estimated by graphical techniques to be:

$$
\begin{aligned}
& \text { below } 7,000 \text { feet }(2,100 \mathrm{~m})-264 \mathrm{mi}^{2}\left(678 \mathrm{~km}^{2}\right) \\
& 7,000-9,000 \text { feet }(2,100-2,750 \mathrm{~m})=138 \mathrm{mi}^{2}\left(355 \mathrm{~km}^{2}\right) \\
& \text { above } 9,000 \text { feet }(2,750 \mathrm{~m})=38 \mathrm{mi}^{2}\left(98 \mathrm{~km}^{2}\right)
\end{aligned}
$$

If generous estimates of mean annual precipitation rates are made (12 in/yr below 7,000 feet elevation, $15 \mathrm{in} / \mathrm{yr}$ in the zone 7,0009,000 feet, and $17 \mathrm{in} / \mathrm{yr}$ above 9,000 feet), then the total annual precipitation on the La Jencia Creek-Nogal Canyon-Socorro Canyon drainage is $313 \times 10^{5}$ acre-ft. If lower precipitation rates are assumed ( 8,12 , and $15 \mathrm{in} / \mathrm{yr}$ respectively), then the total annual precipitation is $2.31 \times 10^{5}$ acre-ft.

The fraction of this precipitation which actually reaches the groundwater system is moot. Figure 8 shows that potential evaporation in the Socorro region is several times greater than precipitation, and the lack of perennial streams anywhere in the area except the Rio Grande attests to the general aridity. Also, most of the precipitation at lower elevations results from thunderstorms 


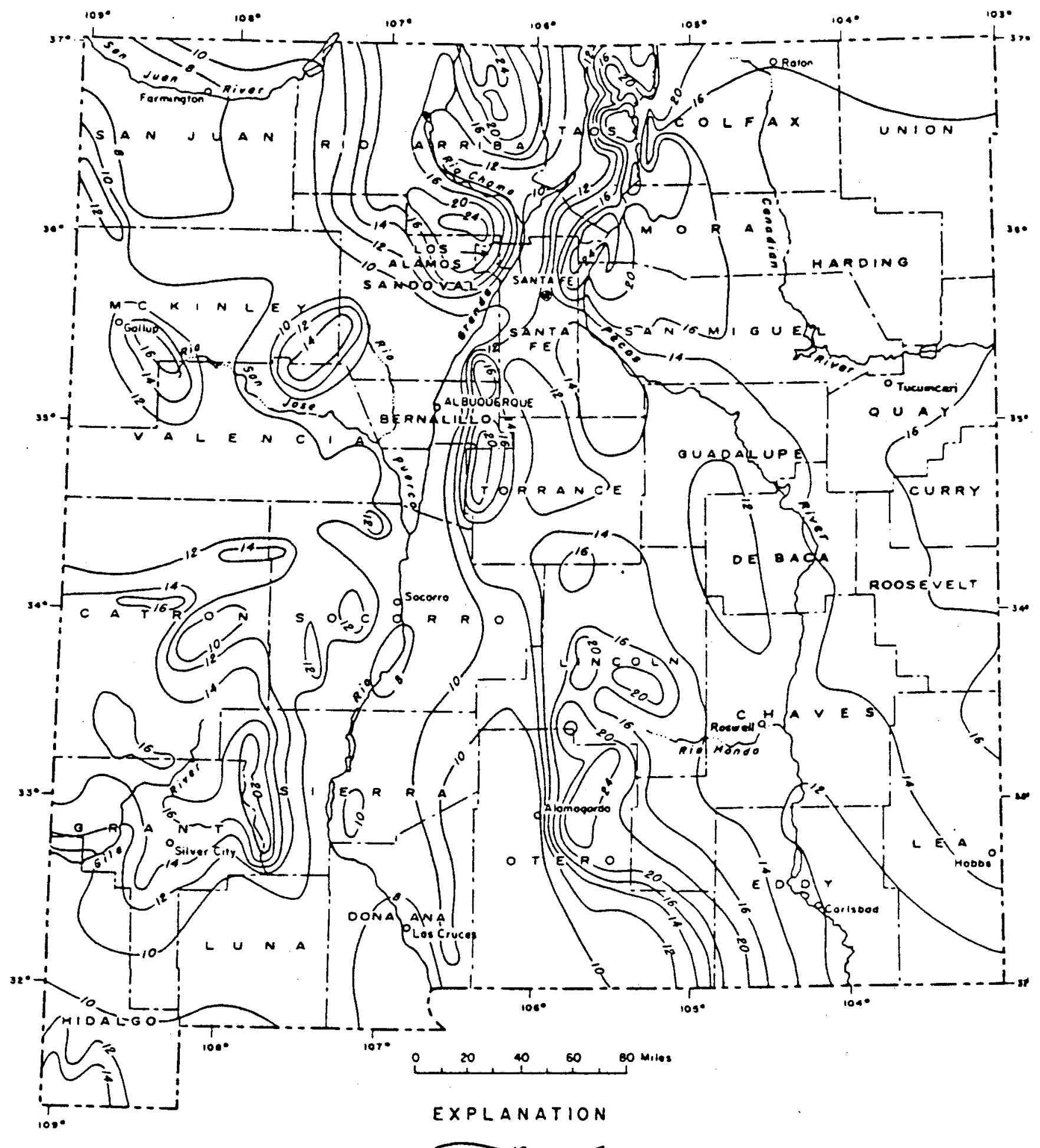

Contour showing equal annual precipitation, in inches, vorioble contour interval

FIGURE 6. Mean annual precipitation, in inches, in New Mexico, 1931-1952. 


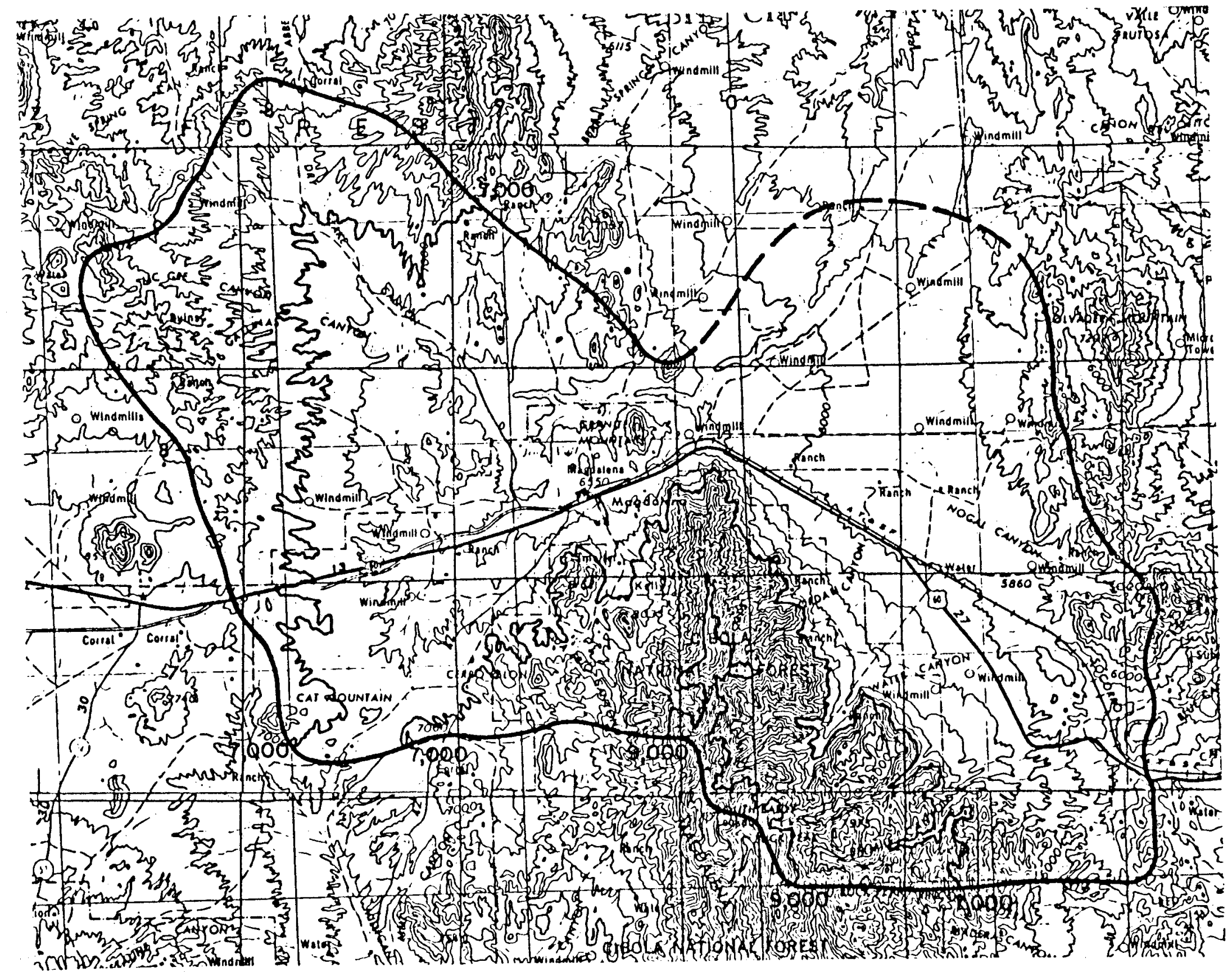

FIGURE 7. Surface dralnage areas of La Jencla Creek and Socorro Canyon within the project area. 


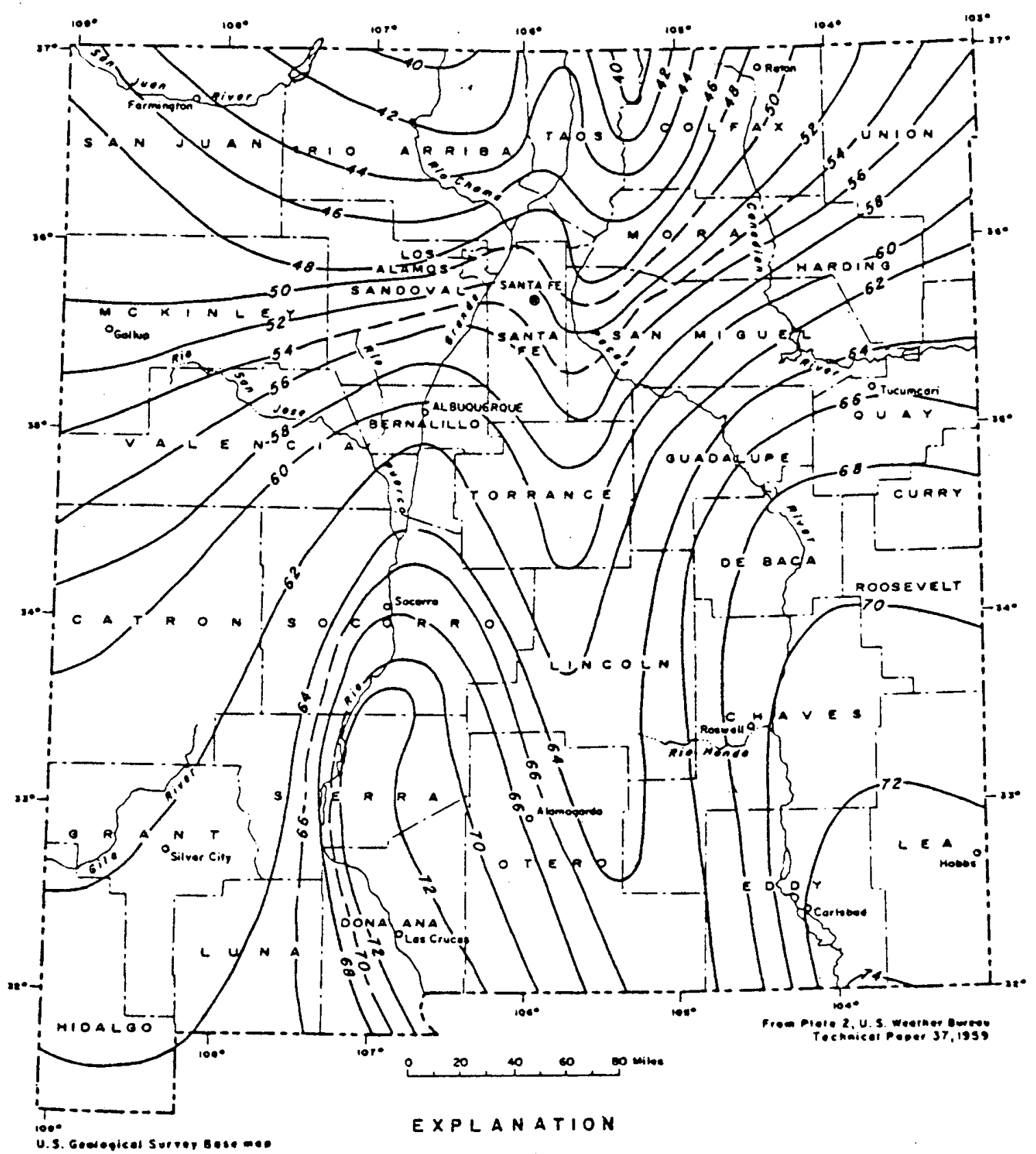

SEA SONAL AESERVOIR EVAPORATION

\begin{tabular}{|c|c|c|c|}
\hline Monin & $\begin{array}{c}\text { Percent } \\
\text { of } \\
\text { onnual }\end{array}$ & Month & $\begin{array}{l}\text { Porcent } \\
\text { of } \\
\text { onnuel }\end{array}$ \\
\hline Jonuery & 1 & Juity & 16 \\
\hline Fobruory & 1 & Augusil & 14 \\
\hline Moreh & 5 & seplember & 12 \\
\hline Aorit & 9 & October & 6 \\
\hline Mor & 14 & Norember & 3 \\
\hline June & 17 & oecember & 2 \\
\hline
\end{tabular}

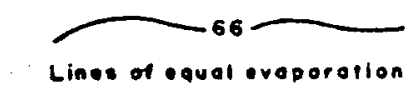

from otallow ecespotrs, in inches

FIGURE 8. Average annual evaporation, in inches, from shallow reservoirs in New Mexico, 1946-1955. 
during the summer months, when the potential for immediate reevaporation is greatest. Overall, it seems likely that only $1 \%$ to a maximum of $10 \%$ of the total precipitation is not immediately re-evaporated, consumed by evapotranspiration, or trapped as soil moisture above the zone of saturation. Under these assumptions, a maximum of 31,000 and a minimum of 2,300 acre-feet of water enters the groundwater system annually. Lacking more precise values, 15,000 acre-feet of annual recharge is assumed, with most of the water entering the west side of the project area.

Recharge is more likely to occur in the Magdalena Mountains and flanking alluvial fans and in the headwaters of La Jencia Creek than at the relatively lower elevations on the east side of the basin.

\section{Direction of Groundwater Movement}

In the west part of the project area, the direction of. groundwater flow was determined from contours drawn on the measured water-table elevation (plate 8 ); it appears generally to follow surface-drainage patterns in the Socorro Canyon, Water Canyon-Nogal Canyon, and La Jencia Creek areas. Groundwater from the north and northwest sides of the Magdalena Mountains drains to the northeast, parallel to La Jencia Creek. Along the east flank of the Magdalena Mountains, the water table has a steep slope, falling from 6,300 feet $(1,900 \mathrm{~m})$ at the mouths of Garcia Canyon and Water Canyon to an elevation of $5,800(1,750 \mathrm{~m})$ feet in less than 1.5 miles $(2.4 \mathrm{~km})$. Groundwater exits the area at Socorro Canyon and at Nogal Canyon.

The most surprising feature of the water table elevation map is the broad flat area shown in the NE-1/4 of T. $2 \mathrm{~S} ., \mathrm{R}$. $3 \mathrm{~W}$., the west half of T. 2 S., R. $2 \mathrm{~W}$., and the central part of T. $3 \mathrm{~S}$. , R. $2 \mathrm{~W}$. Water table elevations between 5,732 and 5,702 feet $(1,748$ and $1,738 \mathrm{~m}$ ) are reported from the north part of 5,726 to 5,720 feet $(1,746$ and $1,744 \mathrm{~m})$ in the south part, but the location of the groundwater divide is not clearly defined. This flat water table could be caused either by very high transmissivities, leading to quick spreading of ground water throughout the area, or by groundwater rising to shallow levels from deep aquifers and causing a gentle "mound" in the water table.

If the inflections of the water table contours at wells \#4 479 and $\$ 200$ fairly represent the direction of flow over the flat 
JAMES B. KOENIG (415) 524-9242

MURRAY C. GARDNER (503) 482-2605

water table, then water at $\$ 1479$ and $\{462$ probably exits the area through Nogal Canyon, whereas water from $\$ 464$, 非 463 , and 非 465 probably exits at Socorro Canyon.

On the east side of the project area near the Rio Grande River, few data are available concerning elevation of the water table, but ground water is assumed to drain east toward the Rio Grande.

Water Temperature

The highest temperature reported from the Socorro area is $103^{\circ} \mathrm{F}\left(39.4^{\circ} \mathrm{C}\right)$ from the water well (\#367) in Sec. 4, T. $3 \mathrm{~S}$. , R. $1 \mathrm{~W}$ (plate 8). This marks the north end of a zone of warm water circulation along the east flank of the Socorro Peak block, which also includes Cook Gallery $\left(56^{\circ} \mathrm{F}\right.$, or $\left.13.3^{\circ} \mathrm{C}\right)$, Socorro Gallery $\left(91^{\circ} \mathrm{F}\right.$, or $33.0^{\circ} \mathrm{C}$ ), and Sedillo (Evergreen) Gallery $\left(92^{\circ} \mathrm{F}\right.$, or $33.5^{\circ} \mathrm{C}$ ) to the south. These are horizontal infiltration galleries driven westward into the mountain to intercept water that formerly supplied natural springs.

Elsewhere, moderately thermal water is reported from well \#233, $84^{\circ} \mathrm{F}\left(29^{\circ} \mathrm{C}\right)$ at 7,000 feet $(2,100 \mathrm{~m})$ on the northwest side of the Magdalena Mountains. Mildly thermal water sources are reported to the northeast near Granite Mountain and in the valley between the Magdalena Mountains and the Socorro Peak block, with the warmest being $73^{\circ} \mathrm{F}\left(23^{\circ} \mathrm{C}\right)$ from well $\# 206$. Warm springs (maximum $70^{\circ} \mathrm{F}$, or $21^{\circ} \mathrm{C}$ ) also are reported near the mouth of La Jencia Creek in T. $1 \mathrm{~N}$., R. 2 E., and a few slightly warm wells occur on the east side of the project area between the Socorro Peak block and the Rio Grande. The warmest is $73^{\circ} \mathrm{F}\left(23^{\circ} \mathrm{C}\right)$ from well 非102, 1 mile north of Nogal Arroyo.

of all these thermal waters, only wells $\# 367$ and $\# 233$, and Socorro, Sedillo, and Cook's Galleries (springs 非33, 非 34 , and 非 35 on plate 8$)$ are more than $18^{\circ} \mathrm{F}\left(10^{\circ} \mathrm{C}\right)$ above local mean annual air temperature, which ranges from $57.5^{\circ} \mathrm{F}\left(14.2^{\circ} \mathrm{C}\right.$ ) at Socorro (elevation $4,585$ feet, or $1,400 \mathrm{~m})$ to $55.6^{\circ} \mathrm{F}\left(13.1^{\circ} \mathrm{C}\right.$ ) at Magdalena (elevation $6,538$ feet, or $1,993 \mathrm{~m})$. The other apparently thermal waters may represent groundwater circulation to only modest depths in an area of average geothermal gradient, with consequently modest warming. 
Published chemical analyses for springs and wells in the Socorro region have been examined. Those samples for which relatively complete data are available are located on plate 8 and summarized on plate 9 . Points for which only fragmentary data are available are represented by notations of major ion concentrations.

Tables 4 and 5 list chemical analyses for springs and wells on the east slope of the Magdalena Mountains, the Socorro Peak block, the intervening areas, and the area along the west bank of the Rio Grande. For the west side of the Magdalena Mountains, analyses for spring \#56 and well 134 are reported in tables 4 and 5 even though they are outside the project area. No other water sources to the south are thought to have any direct influence on groundwater systems in the project area; they are represented only in summary form on plate 9.

Available chemical analyses are grouped on plate 9 by geographical area and lithology of source rock. These groupings also closely parallel the groupings by water quality, as will be discussed in following sections.

\section{Total Dissolved Solids}

Water quality in the project area is good, as is reflected by the fact that most analyzed waters are potable, with total dissolved solids (TDS) less than $500 \mathrm{ppm}$. The maximum reported value is $2,710 \mathrm{ppm}$ for spring 1 1 in the La Jencia area, whereas values as low as $75 \mathrm{ppm}$ are reported for the west side of the Magdalena Mountains. Very low TDS values also are reported for the thermal waters of Socorro, Sedillo, and Cook Galleries; in fact the first two have provided all or part of the drinking water for the city of Socorro for more than 100 years.

There is good correlation of TDS by limited geographical areas, as can be seen from plate 9. Very good quality water is found on the west slope of the Magdalena Mountains in an area of Middle Tertiary andesite and rhyolite flows and breccias, where all reported values for TDS are less than $365 \mathrm{ppm}$, and most are less than $150 \mathrm{ppm}$. On the east side of the Magdalena Mountains, the Garcia Canyon area, which is underlain by Precambrian granitic and metamorphic rocks, has an average TDS of $325 \mathrm{ppm}$; and the Water 
Table 4. Chemical analyses of springs in the Socorro area, New Mexico

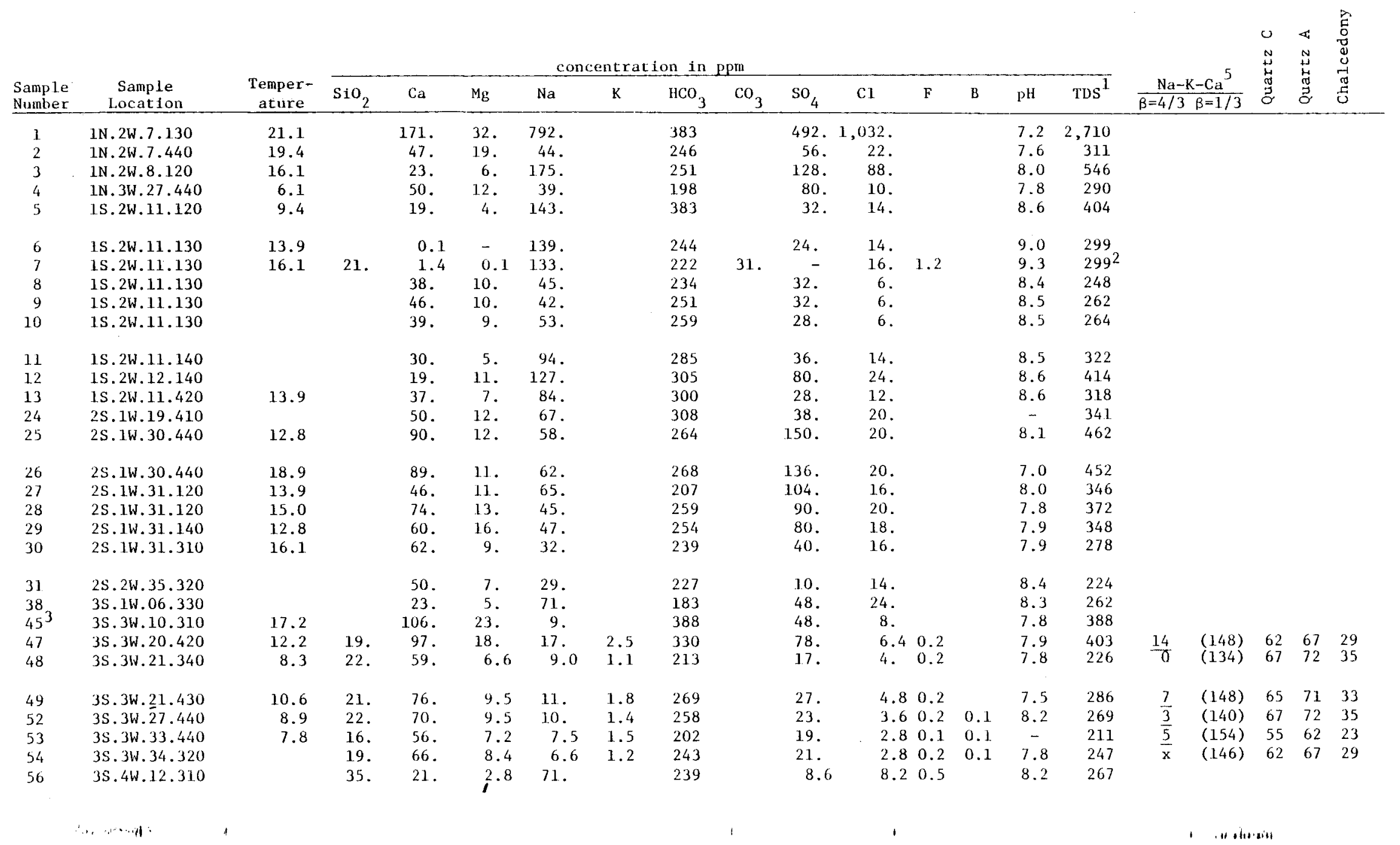


Table 4 (continued)

\begin{tabular}{|c|c|c|c|c|c|c|c|c|c|c|c|c|c|c|c|c|c|c|c|c|}
\hline \multirow[b]{2}{*}{$\begin{array}{l}\text { Sample } \\
\text { Number }\end{array}$} & \multirow[b]{2}{*}{$\begin{array}{c}\text { Sample } \\
\text { Location }\end{array}$} & \multirow[b]{2}{*}{$\begin{array}{c}\text { Temper- } \\
\text { ature }\end{array}$} & \multicolumn{13}{|c|}{ concentration in $\mathrm{ppm}$} & \multirow{2}{*}{\multicolumn{2}{|c|}{$\mathrm{B}=4 / 3 \mathrm{Na}-\mathrm{Ca}{ }^{5}$}} & \multirow{2}{*}{ 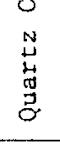 } & \multirow{2}{*}{ 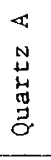 } & \multirow{2}{*}{ 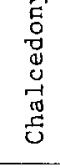 } \\
\hline & & & $\mathrm{SiO}_{2}$ & $\mathrm{Ca}$ & $\mathrm{Mg}$ & $\mathrm{Na}$ & $\mathrm{k}$ & $\mathrm{HCO}_{3}$ & $\mathrm{CO}_{3}$ & $\mathrm{SO}_{4}$ & c1 & $\mathbf{F}$ & B & $\mathrm{pH}$ & $\operatorname{TDS}^{1}$ & & & & & \\
\hline $\begin{array}{c}60 \\
\text { Circ. } \\
\end{array}$ & $\begin{array}{l}4 \mathrm{SS} .10 \mathrm{~W} .05 .210 \\
24\end{array}$ & 17.2 & & 39. & 3. & 372. & & 444 & & 476. & 42. & & & 8.3 & 1,154 & & & & & \\
\hline 03 & $3 \mathrm{~S} .3 \mathrm{~W} .21 .334$ & 10.9 & & 66. & 18. & 13. & 1.8 & 230 & & 36. & 5. & & & 6.7 & 255 & 11 & (144) & & & \\
\hline 04 & 3S. 3W. 21.442 & 10.8 & 22. & 69. & 18. & 12. & 1.5 & - & & 30. & 6. & 0.14 & & 6.9 & $159^{2}$ & $\overline{6}$ & (1.38) & 67 & 72 & 35 \\
\hline $05_{3}$ & $3 S .3$ W. 21.132 & 12.5 & 17. & 150. & 14. & 13. & 1.2 & 260 & & 130. & 10. & 0.12 & & 7.1 & 465 & $\overline{\mathrm{x}}$ & (121) & 57 & 64 & 25 \\
\hline $06^{3}$ & $3 \mathrm{~S} .3 \mathrm{~W} .10 .311$ & 19.0 & 21. & 110. & 16. & 18. & 1.3 & 340 & & 53. & 8. & 0.08 & & 7.2 & 397 & $\mathrm{x}$ & (117) & 65 & 71 & 33 \\
\hline 07 & $3 \mathrm{~S} .3 \mathrm{~W} .09 .341$ & 11.5 & 17. & 100 & 13. & 11. & 1.1 & 330 & & 28. & 9. & 2. & & 7.3 & 346 & $\mathrm{x}$ & (124) & 57 & 64 & 25 \\
\hline 08 & $3 \mathrm{~S} .3 \mathrm{~W} .09 .423$ & 14.0 & 18. & 123. & 16. & 15. & 1.1 & 330 & & 44. & 8. & 0. & & 6.9 & 390 & $\mathrm{x}$ & (115) & 60 & 65 & 27 \\
\hline 09 & $3 \mathrm{~s} .3 \mathrm{~W} .05 .413$ & 11.0 & 16. & 98. & 5. & 5.8 & 1. & 210 & & 31. & 7. & 0.2 & & 7.2 & 269 & $\mathrm{x}$ & (139) & 55 & 62 & 23 \\
\hline 17 & 35.3 W. 27.212 & 16.5 & 17. & 100 & 10. & 14. & 1.8 & 190 & & 56. & 6. & 0.02 & & 6.9 & 300 & $\underline{5}$ & (139) & 57 & 64 & 25 \\
\hline 194 & $3 \mathrm{~S} .4 \mathrm{~W} .01 .432$ & 19.5 & 8. & 9.8 & 9.8 & 36. & 1.2 & 180 & 10 & 37. & 10 & 0.7 & & 8.7 & 208 & $3 \overline{9}$ & (112) & 32 & 41 & $\mathrm{x}$ \\
\hline $33^{4}$ & $3 S .1 W .22 .113$ & 33.0 & & 22.0 & 3.1 & 52.4 & 2.73 & 156.6 & 0.4 & 29.5 & 13.4 & 0.22 & & 8.35 & 202 & $\underline{50}$ & $(129)$ & & & \\
\hline $34_{4}^{4}$ & $3 S .1 W .22 .131$ & 33.5 & & 18.0 & 4.9 & 51.3 & 4.90 & 158.6 & & 30.1 & 12.0 & 0.29 & & 8.25 & 201 & 70 & (158) & & & \\
\hline $35^{4}$ & $35.1 W .15 .313$ & 13.3 & 26. & 13. & 4.0 & 68 & 3.4 & 158. & 3. & 42. & 14. & 0.8 & & 8.4 & 253 & 69 & (135) & 74 & 78 & 42 \\
\hline
\end{tabular}

Notes:

$1_{\text {Calculated }}$

2 Major ion not analyzed; calculated value

${ }^{3}$ Spring $\# 45$ = Spring \#06

${ }^{4}$ From Summers (1976)

${ }^{5}$ Preferred value is underlined. $x$ denotes calculated temperature less than $0^{\circ} \mathrm{C}$. 
Table 5. Chemical analyses of wells in the Socorro area, New Mexico

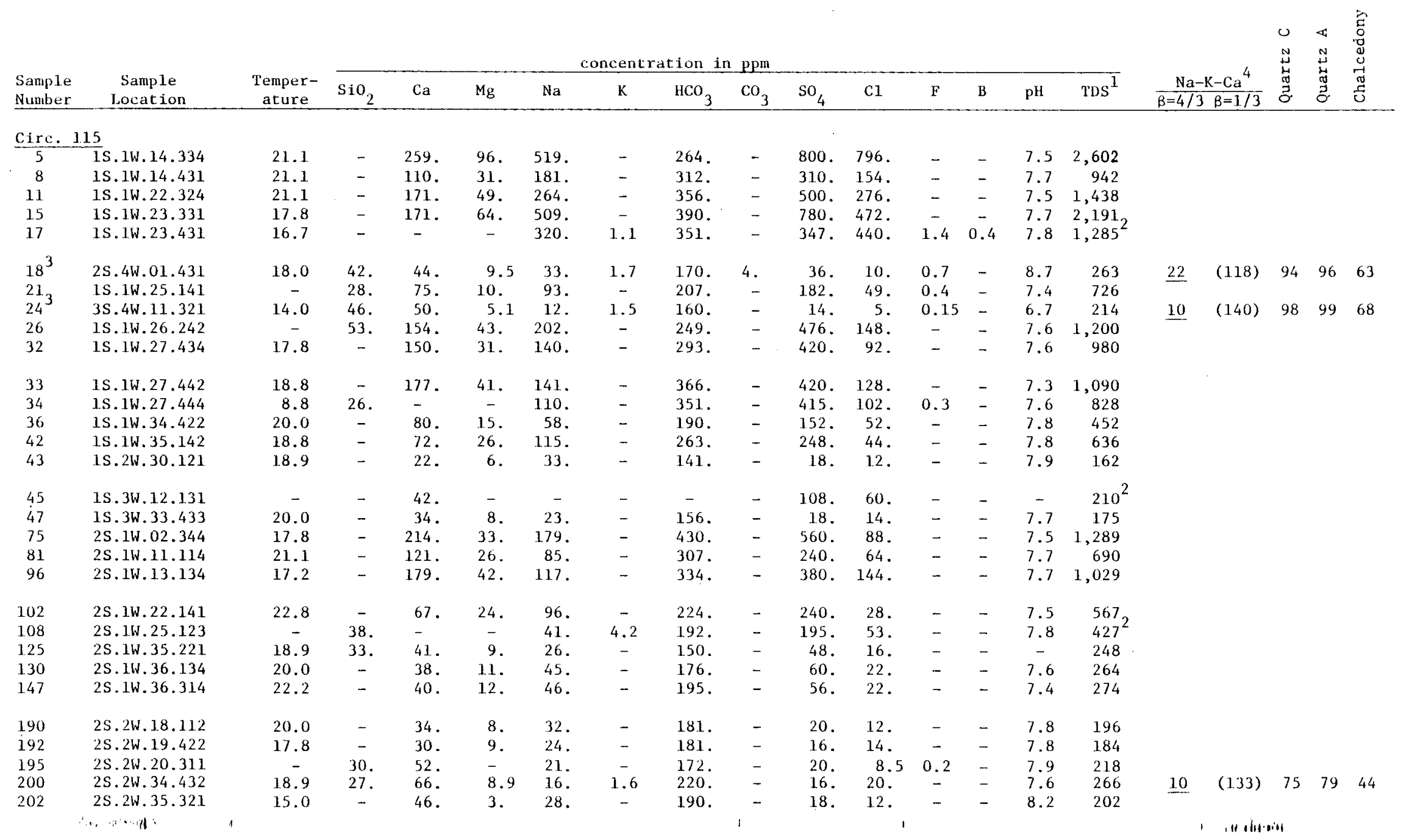


Table 5 (continued)

\begin{tabular}{|c|c|c|c|c|c|c|c|c|c|c|c|c|c|c|c|c|c|c|c|c|}
\hline \multirow[b]{2}{*}{$\begin{array}{l}\text { Sample } \\
\text { Number }\end{array}$} & \multirow[b]{2}{*}{$\begin{array}{c}\text { Sample } \\
\text { Location }\end{array}$} & \multirow[b]{2}{*}{$\begin{array}{c}\text { Temper- } \\
\text { ature }\end{array}$} & \multicolumn{13}{|c|}{ concentration in $\mathrm{ppm}$} & \multirow{2}{*}{\multicolumn{2}{|c|}{$\mathrm{Na}-\mathrm{K}-\mathrm{Ca}{ }^{4}$}} & \multirow{2}{*}{ 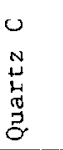 } & \multirow{2}{*}{ 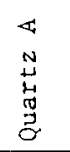 } & \multirow{2}{*}{ 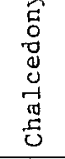 } \\
\hline & & & $\mathrm{SiO}_{2}$ & $\mathrm{Ca}$ & $\mathrm{Mg}$ & $\mathrm{Na}$ & $\mathrm{K}$ & $\mathrm{HCO}_{3}$ & $\mathrm{CO}_{3}$ & $\mathrm{SO}_{4}$ & $\mathrm{Cl}$ & $\mathbf{F}$ & B & $\mathrm{pH}$ & $\operatorname{TDS}^{1}$ & & & & & \\
\hline 203 & 2S.2W. 35.323 & 15.6 & - & 59. & 9. & 20. & - & 200 & - & 16. & 34. & - & - & 7.9 & 238 & & & & & \\
\hline 206 & 2S. 3 W. 01.322 & 22.8 & - & 26. & 7. & 35. & - & 161. & - & 18. & 14. & _- & - & 7.9 & 180 & & & & & \\
\hline 208 & $2 S .3$ W. 07.433 & 21.1 & - & 67. & 15. & - & 10 & 234. & - & 28. & 20. & - & - & 7.6 & 257 & & & & & \\
\hline 209 & 25.3 W. 11.333 & 20.0 & 27. & 30. & 4.1 & 19. & 1.3 & 1.32. & - & 17. & 4.4 & - & - & 7.9 & 169 & 18 & $(124)$ & 75 & 79 & 44 \\
\hline 215 & 2S.3W. 24.411 & - & - & 35. & 9 & 35 . & - & 190. & - & 20. & 14. & - & - & 8.3 & 208 & & & & & \\
\hline 217 & 2 S. 3 W. 25.133 & - & - & 34. & 11. & 25. & - & 171. & - & 20. & 16. & - & - & 7.7 & 192 & & & & & \\
\hline 218 & 2 S. 3 W. 27.223 & 22.8 & - & 44. & 10. & 18. & - & 166. & - & 22 . & 22. & - & _- & 7.8 & 199 & & & & & \\
\hline 221 & $2 \mathrm{~S} .4 \mathrm{~W} .12 .341$ & 17.8 & - & 64. & 19. & - & 29. & 244 . & - & 64. & 24 . & - & - & 7.1 & 322 & & & & & \\
\hline 227 & $2 \mathrm{~S} .4 \mathrm{~W} .23 .321$ & - & - & 67. & 16. & 25 & - & 229. & - & 32. & 18. & - & - & 7.3 & 272 & & & & & \\
\hline 354 & $3 \mathrm{~S} .1 \mathrm{~W} .02 .241$ & - & - & 98. & 25 . & 115 . & - & 310. & - & 292. & 32 . & - & - & 7.6 & 717 & & & & & \\
\hline 362 & $3 \mathrm{~S} .1 \mathrm{~N} .02 .441$ & - & 48. & 87. & 23. & 232 & - & 358. & - & 400 & 70 & 0.3 & - & - & 1,039 & & & & & \\
\hline 367 & $3 \mathrm{~S} .1 \mathrm{~W} .04 .433$ & 39.4 & 23. & 68. & 2.1 & 626 & 38. & 83. & _- & 163. & 945. & 1.1 & 0.6 & 7.7 & 1,908 & 166 & $(146)$ & 69 & 74 & 37 \\
\hline 368 & $3 \mathrm{~S} .1 \mathrm{~W} .07 .314$ & 16.1 & - & 83. & 21. & 53. & - & 224 . & - & 152. & 48. & - & - & 7.4 & 469 & & & & & \\
\hline 373 & $3 \mathrm{~S} .1 \mathrm{~W} .11 .212$ & - & 32. & 65 & 6. & 38. & 1.7 & 1.58 . & - & 106. & 16. & 0.6 & 0.1 & 7.6 & 344 & & & & & \\
\hline 377 & $3 S .1 W .11 .214$ & - & 35. & 115. & 13. & 69. & 3.4 & 220. & - & 228. & 53. & 0.5 & 0.2 & 7.2 & 627 & $\underline{29}$ & (119) & 86 & 89 & 55 \\
\hline 436 & 3s.1W.14.234 & 18.9 & 39. & - & - & 43. & 3.1 & 169. & - & 66. & 18. & 0.7 & 0.1 & - & $254^{2}$ & & & & & \\
\hline 442 & $3 S .1$ W. 16.323 & - & 27. & 20. & 4.6 & 56. & 3. & 163. & - & 36. & 14. & - & - & 7.6 & 242 & 132 & (55) & 75 & 79 & 44 \\
\hline 458 & $3 S .1$ W. 26.311 & - & 43. & - & - & 191. & - & 162. & - & - & 234. & 0.5 & - & 7.6 & $550^{2}$ & & & & & \\
\hline 459 & $35.1 W .27 .331$ & - & 38. & - & - & 61 & 3.2 & 225 . & - & 113. & 23. & 0.8 & 0.1 & 7.9 & $352^{2}$ & & & & & \\
\hline 462 & $3 S .2 W .08 .424$ & 17.8 & - & 61. & 8. & 40. & - & 278 & - & 24. & 14. & - & - & 7.7 & 286 & & & & & \\
\hline 465 & $3 S .2 W .23 .123$ & 17.8 & - & 50. & 7.1 & - & - & 180. & - & - & - & - & - & 7.6 & $147^{2}$ & & & & & \\
\hline 490 & $3 S .3 W .23 .221$ & 15.0 & 22 . & 101. & 14. & 14. & 1.2 & 338. & - & 49. & 6. & - & - & 7.7 & 376 & $\mathrm{x}$ & (121) & 67 & 72 & 35 \\
\hline 497 & 35.3 W. 25.111 & - & - & 62 & 12. & 19. & - & 229. & 5 & 34. & 10. & - & - & 8.5 & 254 & & & & & \\
\hline 498 & $3 \mathrm{~s} .3 \mathrm{~W} .26 .113$ & - & - & 54. & 9. & 15. & - & 188. & 10 & 20 . & 8. & - & - & 8.7 & 205 & & & & & \\
\hline 501 & $3 \mathrm{~s} .3 \mathrm{~W} .34 .332$ & - & - & 65. & 10. & 10. & - & 237. & - & 10 & 15 & - & - & 7.8 & 228 & & & & & \\
\hline 552 & $4 \mathrm{~S} .1 \mathrm{~W} .23 .121$ & - & 38. & - & - & 82 & - & 100. & - & $1] 3$. & 154. & 0.2 & - & - & $437^{2}$ & & & & & \\
\hline Notes: & $\begin{array}{l}1 \text { calculated } \\
2 \text { Major lons } \\
3 \text { From Circula } \\
4 \text { preferred }\end{array}$ & $\therefore \quad$ d & & & 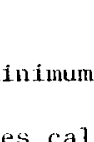 & valu & & & & & & & & & & & & & & \\
\hline
\end{tabular}


JAMES B. KOENIG (415) $524-9242$

MURRAY C. GARDNER (503) 482-2605

Canyon area, which is underlain by volcanic rocks of Oligocene and Miocene age, has lower average TDS (261 ppm). At the north end of the Magdalena Mountains around Granite Mountain average TDS is 324 ppm, which includes one value significantly higher than the other 4 analyses.

Curiously, very low TDS values are reported to the east in the Strozzi Ranch area. The average value for 10 analyses is 188 ppm, and only 2 analyses are above $200 \mathrm{ppm}$. These are much lower than either average values or the majority of individual water analyses to the west; and they demonstrate that groundwater in the Strozzi Ranch area cannot be direct, undiluted recharge from the Magdalena Mountains, because it is hard to devise a believeable process whereby low concentrations of calcium and bicarbonate ions can be removed from groundwater at low temperatures without abundant development of travertine. Instead, groundwater in the Strozzi Ranch area may represent a mixture of recharge from the Magdalena Mountains with a more dilute component from some other source, as is discussed in a later section.

Numerous analyses are available for water in the Socorro Peak block. Average TDS is $295 \mathrm{ppm}$, and the lowest value for a complete analysis is $202 \mathrm{ppm}$ (well 非202). These higher TDS values, as well as groundwater flow patterns discussed in the section on Direction of Groundwater Movement, makes it unlikely that recharge from the Socorro Peak block causes the low observed TDS in the Strozzi Ranch area.

To the north, a group of springs in the San Lorenzo arroyo area has an average TDS of about $351 \mathrm{ppm}$. Springs in the La Jencia drainage have very widely differing but higher (290 to 2,710 ppm) TDS.

On the east side of the project area, wells in the Lemitar area produce more mineralized water, with an average TDS value of $994 \mathrm{ppm}$. Somewhat better-quality water is produced in the vicinity of Socorro between the Socorro Peak block and the Rio Grande, where the average value is $558 \mathrm{ppm}$, although values as high as 1,154 ppm are reported from this area. 
Composition of Dissolved Solids

\section{Anion Composition}

With very few exceptions, bicarbonate ion dominates the anion composition of groundwater in the San Lorenzo and Socorro Peak blocks and all areas to the west. Sulfate ion is commonly 3 to 10 times less abundant (by weight percent) than bicarbonate ion, and chloride ion is insignificant. These relative abundances are very typical of cool groundwater in this region, and in general typify youthful meteoric recharge.

Exceptions to this ranking for the western part of the project area include well $\$ 367$ on the east side of the Socorro Peak block, where chloride ion dominates and bicarbonate ion is relatively less important. Springs in the La Jencia area have somewhat greater sulfate content, and one anomalous spring (非) has predominant chloride.

On the east side of the project area, many of the mineralized wells in the Lemitar area have higher sulfate ion content than bicarbonate ion, and one well (非) has a relatively high proportion of chloride ion. Wells in the Socorro area also tend to have somewhat more abundant sulfate than the groundwater areas to the west. At the south end of the Socorro area, well \#522 has dominant chloride. Sulfate may derive from weathering of volcanic rocks or may come from gypsiferous or lacustrine or evaporite beds of any period. Sulfated waters usually represent longer travelor residence-time underground than do the very dilute bicarbonated waters.

\section{Cation Composition}

Calcium is by far the most abundant cation in ground water on the east slope of the Magdalena Mountains and around Granite Mountain. Sodium and magnesium concentrations are about equal, with no strong trends recognizable in these data. Anomalously

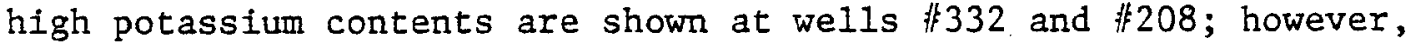
few potassium analyses are available and the distribution of this ion is not well known.

In the Strozzi Ranch area, calcium is the dominant cation in all samples except $\$ 43$ and $\# 206$, which have somewhat more sodium than calcium. In all the other samples, sodium is the second most abundant cation, and magnesium is much less significant. Similar 
JAMES B. KOENIG (415) 524-9242

MURRAY C. GARDNER (503) 482-2605

patterns are observed in the La Jencia area, except that sodium predominates in the anomalous water at spring 1 and also at spring 非3.

The group of springs in the San Lorenzo area show very similar patterns of cation abundances. Sodium predominates and calcium is second most abundant; the relative proportions of cations are similar for all samples. These relations, along with fairly similar TDS, suggest that the springs produce from a homogeneous water source.

In the Lemitar area, the highly mineralized (IDS greater than 1,000 ppm) waters show both calcium-dominated and sodium-dominated compositions. Magnesium is a minor component in all cases where analyses are given.

In the Socorro area, sodium dominates in all samples except wells $\# 373$ and \#377, which have higher calcium. In well \#459, potassium is listed as the second-most abundant cation but this may be spurious, because calcium and magnesium values were not reported in the analysis.

Whereas abundant calcium and magnesium characterize cool meteoric waters, dominant or abundant sodium and potassium usually are indicative of older, deeper-circulation waters. Chloride also is typical of deeper and older sources, possibly including connate waters in Paleozoic marine sediments and/or metamorphic water derived from Precambrian- to Mesozoic-age rocks.

\section{Comparison Between Different Areas}

Relative composition of dissolved solids of ground water in the Socorro area is displayed in plate 10. These diagrams are expressed in percentages of equivalents per liter, rather than weight percent, and show more clearly the chemical characteristics of the water.

Plate 10 shows that the cation and composite plots for waters on the east flank of the Magdalena Mountains (Garcia Canyon and Water Canyon areas) define a distinct field of values that is different from all other groundwaters in the area. The anion composition of the east Magdalena water sources also forms a distinct field, but it is overlapped by the anion composition of samples from the San Lorenzo area. 
The anion and cation compositions of water samples from the Strozzi Ranch area also form coherent fields, which are offset slightly from the east Magdalena water sources, and imply that the observed dissolved-solids compositions could be formed by enrichment of east Magdalena Mountains ground water in chloride and sodium plus potassium. This might come by upwelling of chlorided water from a deeper source, which may be either thermal or non-thermal.

Samples from the Socorro Peak block show scatter in both the anion and cation compositions and in overlap with waters from other areas. However, the composition of water from well 非 367 clearly is anomalous, being more chlorided than any other sample; its sodium-potassium content is comparable only to spring 非60, which lies in the same geographical trend as the warm-water zone on the east side of the Socorro Peak block (plate 9). Cook, Sedillo, and Socorro Galleries and well \#442 have closely similar compositions. We11 \#442 is 1 mile west of Socorro Gallery, but its temperature is not known.

On the east side of the project area, the anion composition of wells in the Lemitar area defines its own broad field, but the cation composition is similar to many other waters.

Water sources in the Granite Mountain, La Jencia, and San Lorenzo areas show much scatter of composition, indicating that several different water types are present in these areas.

\section{Mixing Models}

In this section, the groundwater in the Strozzi Ranch area is discussed in more detail, and qualitative limits are set for possible inflow from a deep aquifer.

Five analyses for four springs in Jordan Canyon and Garcia Canyon on the east slope of the Magdalena Mountains are given in table 4 and summarized on plate 9. Averages of TDS and six major ions are shown in table 6 (Composite A); this composition may be taken to represent groundwater recharge from the northeast side of the Magdalena Mountains to the La Jencia drainage area. As can be seen from the water-table contours on plate 8 , the recharge moves northeast toward wells 非17 and 非18, and then probably to the northeast or north.

The calculated.TDS of Composite $A$ is $358 \mathrm{ppm}$, which is $80 \%$ higher than that reported for wells \# 218 or $\# 217$, the sample points 
Table 6. Major ion and TDS compositions of ground water and calculated mixing components, east Magdalena Mountains and Strozzi Ranch area.

$\underline{\mathrm{Ca}} \quad \underline{\mathrm{Mg}} \quad \underline{\mathrm{Na}} \quad \begin{gathered}\mathrm{HCO}_{3}{ }^{+} \\ -\mathrm{CO}_{3}\end{gathered} \mathrm{SO}_{4} \quad \underline{\mathrm{Cl}} \quad \underline{\mathrm{TDS}^{1}} \quad$ Water Type

\begin{tabular}{|c|c|c|c|c|c|c|c|c|}
\hline Composite $\mathrm{A}^{2}$ & 107 & 15 & 12 & 320 & 41 & 8 & 358 & $\begin{array}{l}\mathrm{Ca}>>\mathrm{Mg}>\mathrm{Na} \\
\mathrm{HCO}_{3}>>\mathrm{SO}_{4}>>\mathrm{Cl}\end{array}$ \\
\hline We11 非217 & 34 & 11 & 25 & 171 & 20 & 16 & 192 & $\begin{array}{l}\mathrm{Ca}>\mathrm{Na}>\mathrm{Mg} \\
\mathrm{HCO}_{3}>>\mathrm{SO}_{4}>\mathrm{Cl}\end{array}$ \\
\hline $\begin{array}{l}\text { Deep Component } \\
\text { at } 70 \% \text { of } \|^{2} 217\end{array}$ & 3 & 9 & 31 & 107 & 11 & 19 & 121 & $\begin{array}{l}\mathrm{Na}>>\mathrm{Mg}>\mathrm{Ca} \\
\mathrm{HCO}_{3}>>\mathrm{C} 1>\mathrm{SO}_{4}\end{array}$ \\
\hline at $80 \%$ of $\# 217$ & 16 & 10 & 28 & 134 & 15 & 18 & 150 & $\begin{array}{l}\mathrm{Na}>\mathrm{Mg}>\mathrm{Ca} \\
\mathrm{HCO}_{3}>>\mathrm{Cl}>\mathrm{SO}_{4}\end{array}$ \\
\hline at $90 \%$ of $\#^{2} 217$ & 26 & 11 & 26 & 154 & 18 & 17 & 174 & $\begin{array}{l}\mathrm{Na}=\mathrm{Ca}>\mathrm{Mg} \\
\mathrm{HCO}_{3}>>\mathrm{SO}_{4}=\mathrm{Cl}\end{array}$ \\
\hline We11 \#206 & 26 & 7 & 35 & 161 & 18 & 14 & 180 & $\begin{array}{l}\mathrm{Na}>\mathrm{Ca}>>\mathrm{Mg} \\
\mathrm{HCO}_{3}>>\mathrm{SO}_{4}>\mathrm{CI}\end{array}$ \\
\hline $\begin{array}{l}\text { Deep Component } \\
\text { at } 80 \% \text { of }\left.\right|_{12} 206\end{array}$ & 6 & 5 & 41 & 121 & 12 & 16 & 136 & $\begin{array}{l}\mathrm{Na}>>\mathrm{Ca}>\mathrm{Mg} \\
\mathrm{HCO}_{3}>>\mathrm{Cl}>\mathrm{SO}_{4}\end{array}$ \\
\hline at $90 \%$ of $\$ 206$ & 17 & 6 & 38 & 143 & 15 & 15 & 160 & $\begin{array}{l}\mathrm{Na}>\mathrm{Ca}>\mathrm{Mg} \\
\mathrm{HCO}_{3}>>\mathrm{SO}_{4}>\mathrm{Cl}\end{array}$ \\
\hline at $95 \%$ of $\# 206$ & 22 & 7 & 36 & 153 & 17 & 14 & 170 & $\begin{array}{l}\mathrm{Na}>\mathrm{Ca}>>\mathrm{Mg} \\
\mathrm{HCO}_{3}>>\mathrm{SO}_{4}>\mathrm{Cl}\end{array}$ \\
\hline Wel1 非 43 & 22 & 6 & 33 & 141 & 18 & 12 & 162 & $\begin{array}{l}\mathrm{Na}>\mathrm{Ca}>>\mathrm{Mg} \\
\mathrm{HCO}_{3}>>\mathrm{SO}_{4}>\mathrm{Cl}\end{array}$ \\
\hline We11 \# 462 & 61 & 8 & 40 & 278 & 24 & 14 & 285 & $\begin{array}{l}\mathrm{Ca}>\mathrm{Na}>>\mathrm{Mg} \\
\mathrm{HCO}_{3}>>>\mathrm{SO}_{4}>\mathrm{Cl}\end{array}$ \\
\hline Composite $\mathrm{B}^{3}$ & 78 & 12 & 12 & 246 & 39 & 6 & 285 & $\begin{array}{l}\mathrm{Ca}>>\mathrm{Na}=\mathrm{Mg} \\
\mathrm{HCO}_{3}>>\mathrm{SO}_{4}>>\mathrm{Cl}\end{array}$ \\
\hline
\end{tabular}

${ }^{1}$ Calculated

2 Average of 15 analyses. Note that the TDS value is also an average, not the sum of the averaged major ions.

3 Average of 14 analyses. 
JAMES B. KOENIG (415) 524-9242

MURRAY C. GARDNER (503) 482.2605

closest to the Magdalena Mountains. These wells are moderately deep ( 420 and 280 feet, or 128 and $85 \mathrm{~m}$, respectively) and the water surface in 218 is 347 feet (106 m) below land surface; given the aridity of the area, it is very unlikely that the lower TDS reported here is caused by direct infiltration of precipitation.

Tables 4 and 5 and plate 9 show that groundwater in the Strozzi Ranch area is somewhat enriched in sodium and slightly enriched in chloride relative to groundwater in the Jordan CanyonGarcia Canyon areas. Such slight changes in relative concentrations can be caused by ion exchange and absorption processes as the groundwater percolates through the alluvial fill; but the decrease in TDS cannot easily be caused by such processes. The low TDS content is caused either by mixing of recharge from the Magdalena Mountains with groundwater of lower TDS, or having the wells in the Strozzi Ranch area tap an unmixed aquifer not associated with present-day recharge.

Table 6 shows the composition and calculated fraction of theoretical mixing components which could produce the observed groundwater composition from Composite A. These calculations are intended only as guidelines, since no provision is made for any change in the composition of Composite A during eastward percolation through the alluvium. Also, no estimate can be made of reservoir temperatures or the fraction of geothermal fluid that might be present, as no silica or potassium analyses are available and thus neither the $\mathrm{SiO}_{2}$ nor the $\mathrm{Na}-\mathrm{K}-\mathrm{Ca}$ geothermometer can be applied.

It is uncommon for cool or warm groundwater in an alluvial basin in an arid region to have TDS lower than $100 \mathrm{ppm}$; therefore, this value can be taken as the lower limit of a potential mixing component. The upper limit is the observed TDS at the wells in the Strozzi Ranch area.

Table 6 shows that the observed water composition at well \#217 can be explained as a mixture of 70-90\% 121-174 ppm water with 10-30\% fraction of Composite $A$. The water composition at well \#206 can be explained by $80-95 \%$ fraction of $136-170$ ppm water with $5-20 \%$ fraction of Composite $A$.

The observed composition at well \#43 is so close to the calculated composition of the deep component at we11 非206 that it may represent this aquifer (TDS $=162 \mathrm{ppm}$ ) without admixture of recharge from the Magdalena Mountains or Socorro Peak block. 
Thus, the wells in the Strozzi Ranch area mainly produce water with TDS 150-170 ppm, affected by some mixture with recharge water of higher TDS. The low TDS water is of the sodium-bicarbonate type, as is shown in table 6 .

Water at well \#462, in the south part of the Strozzi Ranch area, may represent westward groundwater flow without mixing with another water source. At $286 \mathrm{ppm}$, the TDS of this sample is lower than some analyses of springs and well waters in the Magdalena Mountains, but arithmetic averages of TDS and of the six major ions of all water sources in the Water Canyon surface-drainage basin gives results closely comparable to the composition at $\$ 462$ (table 6).

\section{Geothermometry}

\section{Silica Geothermometer}

Generally low values of silica were found in the available analyses (maximum $53 \mathrm{ppm}$ for well 非6); and correspondingly low reservoir temperatures are calculated (table 4 and 5); but these should be used with caution because low concentrations of silica may be metastable.

Reservoir temperatures that assume equilibration with quartz show no significant difference between calculations for conductive or adiabatic cooling of the water. Calculations assuming equilibration with chalcedony gave lower results, and calculations assuming equilibration with amorphous silica gave unreasonably low temperatures (less than observed outlet temperature) and are not considered further.

The highest calculated temperatures are $201-210^{\circ} \mathrm{F}\left(94-99^{\circ} \mathrm{C}\right)$ for wells \#18 and $\# 24$, which are on the northwest side of the Magdalena Mountains. In the Socorro area, one well (\$377) has a calculated temperature of about $190^{\circ} \mathrm{F}\left(88^{\circ} \mathrm{C}\right)$.

Many wells, including $\$ 367$ and 4442 in the Socorro Peak block and $\# 200$ and $\left.\right|^{209}$ in the Strozzi Ranch area, have calculated temperatures in the $167-174^{\circ} \mathrm{F}\left(75-79^{\circ} \mathrm{C}\right)$ range. Of the thermal springs, Cook Gallery and Socorro Gallery also yield reservoir temperatures of 167$174^{\circ} \mathrm{F}\left(75-79^{\circ} \mathrm{C}\right)$.

\section{Alkalai Geothermometer}

Because relatively few of the available analyses give potassium values, the $\mathrm{Na}-\mathrm{K}-\mathrm{Ca}$ geothermometer described by Fournier and 
JAMES B. KOENIG (415) 524-9242

MURRAY C. GARDNER (503) 482.2605

Truesdell (1973) can be applied to only a few data points. Results are given in tables 4 and 5 .

The highest computed reservoir temperature is $295^{\circ} \mathrm{F}\left(146^{\circ} \mathrm{C}\right)$ for well \#367 on the east side of the Socorro Peak block, which is very much higher than the $156-165^{\circ} \mathrm{F}\left(69-74^{\circ} \mathrm{C}\right)$ computed by the silica geothermometer for this sample. The disagreement may indicate that a thermal component has mixed with cool, dilute water to yield lower silica concentrations and consequently lower calculated reservoir temperatures. However, this is speculative.

Reservoir temperatures calculated by the $\mathrm{Na}-\mathrm{K}-\mathrm{Ca}$ method for Socorro, Sedillo, and Cook Galleries and well $\$$ " 442 are $122-158^{\circ} \mathrm{F}$ $\left(50-70^{\circ} \mathrm{C}\right)$, very close to the results calculated by the silica geothermometer. This close agreement plus their low observed TDS, argues strongly against mixing of a thermal component with dilute groundwater. Instead, the water issuing from these springs apparently last equilibrated at temperatures considerably below $212^{\circ} \mathrm{F}$ $\left(100^{\circ} \mathrm{C}\right)$.

Anomalously low (from less than 0 to $14^{\circ} \mathrm{C}$ ) temperatures are computed by the $\mathrm{Na}-\mathrm{K}-\mathrm{Ca}$ method for springs $\$$ 47-54 and $\# 04-19$ in the Magdalena Mountains. These very low results probably represent disequilibrium conditions, where cool groundwater either does not reside at depth long enough to reach thermally appropriate chemical equilibrium, or obtains excess $\mathrm{Ca}$ and/or $\mathrm{Na}$ from connate waters or evaporite beds.

\section{Zones of Thermal Water Circulation}

Available hydrochemistry and hydrology indicate that the most marked zone of thermal water circulation occurs along the east side of the Socorro Peak block. This includes Sedillo, Socorro, and Cook Galleries, as well as well \#367 (plate 8). To the north, data are sçanty, but the relatively high temperature gradients reported in holes B15 and B9 may indicate similar warm water circulation. As can be seen from plate 1, NNW-trending faults along the east side of the Socorro Peak block may provide permeable channe1ways for the thermal water.

Elsewhere, very mildly warm water $\left(90^{\circ} \mathrm{F}\right.$, or $\left.32.0^{\circ} \mathrm{C}\right)$ is moving at a depth of 1,391 feet $(424 \mathrm{~m})$ in hole $B 40$ in the northern Chupadera Mountains. In the southern part of the Socorro Peak block, we11 \$442 
JAMES B. KOENIG (415) 524-9242

MURRAY C. GARDNER (503) 482-2605

has hydrochemical characteristics similar to the thermal springs one mile east, but its temperature is not known.

of the available temperature and hydrochemical data, only well \#367 in Sec. 4, T. 3 S., R. $1 \mathrm{~W}$. gives any indication of a thermal component in excess of $212^{\circ} \mathrm{F}\left(100^{\circ} \mathrm{C}\right)$. The anomalous TDS and high reservoir temperatures calculated for this well by the $\mathrm{Na}-\mathrm{K}-\mathrm{Ca}$ method indicate the possibility of a deep, hot component in the water. However, single-point anomalies are as questionable and as subject to misinterpretation in hydrochemistry as in any other kind of survey; and without supporting data, it cannot be concluded that a strong hydrothermal anomaly has been demonstrated.

The thermal waters at Socorro, Sedillo, and Cook Galleries are weak features. Their very low TDS, relatively mild temperatures, and low $\left(122-158^{\circ} \mathrm{F}\right.$, or $\left.50-70^{\circ} \mathrm{C}\right)$ calculated reservoir temperatures, which were derived by both the silica and $\mathrm{Na}-\mathrm{K}-\mathrm{Ca}$ geothermometers, can all be explained by circulation to modest depth in a background temperature-gradient regime of $1.7^{\circ} \mathrm{F} / 100 \mathrm{ft}\left(30^{\circ} \mathrm{C} / \mathrm{km}\right)$.

The source of recharge for the water of Socorro, Sedillo, and Cook Galleries has not been determined clearly. TDS is somewhat lower than in most analyses in the apparent recharge area, the Magdalena Mountains; also the composition of TDS is somewhat different. However, the springs cannot represent water from long-term storage, because tritium $\left({ }^{3} \mathrm{H}\right)$ concentrations in Socorro Spring waters during the period 1957-1959 show sharp increases, apparently representing precipitation contaminated by hydrogen bomb tests no more than 4 years previously (Holmes, 1963). As was discussed in the section on Recharge, the Socorro Peak block apparently contributes little recharge to the groundwater system.

Therefore, the thermal springs at Socorro represent groundwater which has moved relatively quickly from the Magdalena Mountains and been warmed to a maximum of about $158^{\circ} \mathrm{F}\left(70^{\circ} \mathrm{C}\right)$. Surface elevations highlighted on plate 3 show that this path is reasonable.

The zone of deep water upwelling postulated for the Strozzi Ranch area, on the other hand, may represent movement from long-term storage. The water appears to be cool, since subaverage temperature gradients and heat flow are observed in this area. Very slightly warm temperatures for the given elevation are reported for wells 非190 and $\# 206\left(68-73^{\circ} \mathrm{F}\right.$, or $\left.20-23^{\circ} \mathrm{C}\right)$, but sampling conditions are unknown and sun-warming of the water or other spurious effects cannot be ruled out. 


\section{DISCUSSION}

The Socorro area has been mentioned widely as an attractive geothermal prospect. The principal lines of evidence for supposing the area to have good potential are: seismic evidence for present-day midcrustal and shallow magma bodies, reports of high regional heat flow (greater than 2.5 HFU) based largely on two very high measurements at a single locality, Tertiary rhyolitic and basaltic volcanism and possible caldera formation, thermal springs, and modern faulting and deformation.

However, the proprietary temperature gradient and heat flow data of Gulf Mineral Resource Company and Sunoco Energy Development Co. suggest average to subaverage temperature conditions at depth. When integrated with published data, no potent heat source or strong hydrothermal convection system can be identified. In fact, if such heat sources or convection systems are present, they are weak enough to be effectively masked by moderate volumes of circulating cool groundwater.

The lack of favorable temperature data calls into review the three basic components of a geothermal system: heat source, reservoir, and water as a medium to transport the heat.

\section{Heat Source}

Unlike most geothermal prospect areas, the Socorro region has direct evidence of present-day magma in the subsurface. The seismic data unequivocally show a zone of low rigidity, which apparently can only be liquid magma or a zone of partial melt, at a depth of about 12 miles $(19 \mathrm{~km})$. However, the immediate project area is not unique in having this magma body, because the well-known lowrigidity zone extends at least 35 miles $(56 \mathrm{~km})$ north of Socorro, and another low-rigidity zone at comparable depth recently has been recognized 15 miles $(25 \mathrm{~km}$ ) east of Socorro (0lsen et al., 1979).

That these magma bodies are quite recent seems likely from the fact that they behave as partially or entirely liquid, despite being very thin (average about 3,000 feet, or $1 \mathrm{~km}$ ) compared to areal extent. Conversely, relatively recent intrusive bodies may be present, which have solidified but still are hot. Such bodies would act rigidly to seismic waves and might not be detected in 
JAMES B. KOENIG (415) 524-9242

MURRAY C. GARDNER (503) 482-2605

these studies, depending upon assumptions made regarding deep crustal density.

The existence of present-day magma at mid-crustal levels does not guarantee that enough heat is present at shallow crustal levels to drive a significant hydrothermal convection system. First, if the mid-crustal magma bodies have been injected recently, there may be a substantial time lapse (tens of thousands of years) before heat moves by conduction from 12 miles $(20 \mathrm{~km})$ to 3 miles $(5 \mathrm{~km})$, where large-scale interaction with groundwater could take place.

Second, even if equilibrium conductive heat transfer has been established by earlier intrusions or if the general isotherms at 12 miles $(20 \mathrm{~km})$ depth are near $1,800^{\circ} \mathrm{F}\left(1,000^{\circ} \mathrm{C}\right)$, the regional conductive temperature gradient would be about $2.8^{\circ} \mathrm{F} / 100 \mathrm{ft}\left(50^{\circ} \mathrm{C} / \mathrm{km}\right)$. Gradients of this magnitude are not unusual, and unless hydrologic convection is available to transfer the heat to shallow levels, a moderately high temperature gradient like this does not guarantee an attractive target. In such conductive heat transfer conditions, holes would need to be $10,000-13,000$ feet $(3-4 \mathrm{~km})$ deep to reach temperatures in the $300-400^{\circ} \mathrm{F}\left(150-200^{\circ} \mathrm{C}\right)$ range.

In other geothermal areas, young (less than $1 \mathrm{m.y.}$ ) silicic volcanics or very young (less than $0.1 \mathrm{m.y.}$ ) basaltic volcanics have been cited as evidence for shallow crustal igneous bodies that may act as heat sources to geothermal systems. In the Socorro area, the youngest known rhyolitic units are $7 \mathrm{~m} . \mathrm{y}$. and the youngest basalt unit is $4 \mathrm{~m} . \mathrm{y}$. These are much too old to affect the present-day thermal regime.

Small shallow magma bodies postulated to exist in the south part of the Socorro Peak block from microseismic data are thought to contain very small fractions of magma; their influence on hydrothermal circulation is moot.

\section{Water Circulation}

In almost every geothermal system discovered to date, the local or regional groundwater area shows distinctive chemical patterns reflecting the influence by a high-temperature regime at depth. This influence may appear also as elevated temperatures of springs and wells and in flow patterns that show upwelling from deep sources. 
JAMES B. KOENIG (415) 524-9242

MURRAY C. GARDNER (503) 482.2605

Much information has been developed for this report on the flow patterns and chemistry of groundwater in the Socorro area, but no strong thermal component has been identified with assurance. Only well $\$ 367$ on the east side of the Socorro Peak block with $\mathrm{Na}-\mathrm{Cl}$ type water, has a good possibility with evidence of having equilibrated chemically at temperatures above $212^{\circ} \mathrm{F}\left(100^{\circ} \mathrm{C}\right)$.

Conversely, of the recognized thermal springs néar Socorro, their temperature, composition, and TDS is entirely consistent with modest warming by circulation to moderate depth under a temperaturegradient regime of only $1.7-2.8^{\circ} \mathrm{F} / 100 \mathrm{ft}\left(30-50^{\circ} \mathrm{C} / \mathrm{km}\right)$. This is compatible with the deeper temperature gradient data used in this report. Other authors have suggested that these springs are a priori evidence of a geothermal system; detailed hydrology and hydrochemistry shows this assumption to be unconvincing.

Evidence of deep water circulation was found in the La Jencia Creek-Socorro Canyon area on the west side of the project area; but the hydrochemical, temperature gradient, and heat flow data imply that this circulation is of subaverage temperature, representing rapid flow through porous rocks at depth, without thermal re-equilibration. This tends to discourage further exploration efforts in the area.

\section{Reservoir}

Reservoir potentially is present beneath many parts of the Socorro area, especially as the Paleozoic limestones could have both fracture and solution-cavity permeability, and virtually all of the units except the fine-grained Popotosa formation could support fracture permeability.

However, pending determination that significant thermal water is present, the question of reservoir cannot be discussed in detail.

\section{CONTINUED ACTION}

It can be expected that various academic or institutional researchers will perform further seismologic and geoelectrical studies of the probable magmatic zone. These studies may help to resolve questions of dimension, exact location, fluid percentage, 
temperature and deep roots of the presumed magmatic bodies. Similarly, there may continue to be hydrologic and/or hydrochemical measurements of particular springs or well waters, in the attempt to identify gases, solutes or isotopes of magmatic origin. Despite the detailed geologic mapping that exists in the Socorro area, a broadly acceptable geologic picture is not yet available.

Briefly, further geologic mapping in the region is needed because identified faults do not agree with the boundaries of presumed Tertiary volcanic cauldrons, and because the resulting cross-sectional structure is contrived and unconvincing. Indeed, decent subsurface geology would require both deep drilling and detailed seismic reflection surveys, both of which are very expensive, and are not likely to occur unless the geothermal prospect is upgraded by work presently underway. Complexity of the subsurface section, and the probability of encountering high-velocity units at variable (and possibly shallow) depth, tends to preclude active seismic profiling at this time. Cost alone would argue against such a study.

The value of shallow gradient drilling accomplished to date is clear. However, further shallow drilling is likely only to add detail to a picture that already is obvious, and not to resolve the deeper regime. Deeper drilling (say to 2,000 or 2,500 feet) will be expensive and complex because of widely varying lithologies and aquifer characteristics at depth, but such drilling offers the only immediate potential for: (a) resolving questions of deep hydrologic flow and temperature, (b) determining deep temperature gradient, and (c) observing deeper geologic structure and stratigraphy. However, there is no assurance that holes even to 2,500 feet will penetrate beneath the principal meteoric-recharge aquifer. That is, holes to 2,500 feet may observe only another portion of the aquifer-aquiclude system represented by alternating isothermal and high-gradient zones.

Costs for such holes, at an average of $\$ 40$ per foot, might be $\$ 80,000$ to $\$ 100,000$, exclusive of permitting, data evaluation and management. The value of data to be obtained must be weighed against other budgetary considerations, and against the less-than-first-class nature of the prospect.

If no deep gradient drilling is done, the project probably will remain in a second-class limbo: not abandoned, because of its apparent magmatic heat source, but not attractive enough to do more than pay yearly rentals. The property under lease might best be handled through a farm-out operation, with the recipient obligated to drill a series of 2,000-2,500 foot gradient holes. As mentioned 
JAMES B. KOENIG (415) 524-9242

MURRAY C. GARDNER (503) 482-2605

above, the apparent magmatic heat source precludes full abandonment of the prospect at this time.

Should deep gradient $(2,000-2,500$ feet $)$ holes be considered, it is recommended that at least two be drilled. Reasonable locations for these would be:

a. near S8, in S-1/2 Sec. 11, T. $3 \mathrm{~S},, \mathrm{R}, 2 \mathrm{~W}$.

b. on the east side of the Lemitar Range, in Sec. 18 or 19, T. 2 S., R. 1 W.

Along with this gradient drilling, or immediately preceding it, additional geochemical prospecting would be useful in the Socorro Peak-Strozzi Ranch area. This would have as its aim: obtaining complete chemical analyses for those waters with only partial analyses, obtaining chemical and isotope data for possible magmatic constituents ( $\mathrm{H}_{2}$ and $\mathrm{NH}_{3}$ gas, isotope $34 \mathrm{~S}$ ), recognition of possible connate-water aquifers ( $\mathrm{Br} / \mathrm{CL}$ ratio), and improved geothermometry ( $\mathrm{Na}-\mathrm{K}-\mathrm{Ca}$, and $\mathrm{O}_{2}$

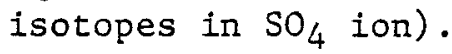

Cost for such detailed work might run $\$ 30,000$ complete. It would be warranted only if a decision were made to continue detailed exploration, leading to deep drilling. If a magmatic source were recognized in spring or well waters, a re-interpretation of thermal regime (and possibly of drilling strategy would be called for).

Re-interpretation of structure and subsurface relationships would await results of deep gradient holes. Again, only if magmatic emissions were recognized through hydrochemical surveys would it be advisable to begin remapping of the Socorro-Strozzi Ranch block prior to such drilling. Cost for this would vary with size of map area and required detail.

Should drilling to 2,000-2,500 feet, or further geochemistry, reveal a surprisingly strong anomaly, improvement of existing land positions would become the major objective. 
JAMES B. KOENIG (415) 524-9242

MURRAY C. GARDNER (503) 482.2605

\section{REFERENCES}

Brown, L. D., Krumhansl, P. A., Chapin, C. E., Sanford, A. R., Cook, F. A., Kaufman, S., Oliver, J. E., and Schilt, F. S., 1979, COCORP seismic reflection studies of the Rio Grande Rift: in Rio Grande Rift: Tectonics and Magmatism, ed. by R. E. Riecher: Amer. Geophysical Union, p. 169-184.

Chamberlin, R. M., 1978, Geologic map of the Lemitar, Socorro, and northern Chupadera Mountains, Socorro County, New Mexico: New Mexico Bureau Mines and Mineral Resources, Open-File Map, 6 sheets.

Chapin, C. E., Chamberlin, R. M., Osburn, G. R., Sanford, A. R., and White, D. W., 1978, Exploration framework of the Socorro geothermal area, New Mexico: New Mexico Bureau of Mines and Mineral Resources, Open-File Report, 68 p.

Clark, N. J., and Summers, W. K., 1971, Records of wells and springs in the Socorro and Magdalena areas, Socorro County, New Mexico, 1968: New Mexico State Bureau of Mines and Mineral Resources, Circular 115, 51 p.

Fournier, R. O., and Truesdel1, A. H., 1973, An empirical Na-K-Ca geothermometer for natural waters: Geochim. et Cosmochim. Acta, v. 37, p. 1255-1275.

Holmes, C. R., 1963, Tritium studies, Socorro Spring: in New Mexico Geological Society, 14th Field Conference Guidebook, p. 152154 .

Keller, G. R., Braile, L. W., and Schlue, J. W., 1979, Regional crustal structure of the Rio Grande Rift from surface wave dispersion measurements: in Rio Grande Rift: Tectonics and Magmatism, ed. by R. E. Riecher: Amer. Geophysical Union, p. $115-126$.

Kelley, V. C., 1952, Tectonics of the Rio Grande depression of central New Mexico: New Mexico Geological Society, 3rd Field Conference Guidebook, p. 92-105.

Krewedl, D. A., 1974, Geology of the central Magdalena Mountains, Socorro County, New Mexico: unpub. Ph.D. dissert., University of Arizona, $128 \mathrm{p}$. 
JAMES B. KOENIG (415) 524-9242

MURRAY C. GARDNER (503) 482-2605

Laughlin, G. F., and Koschmann, A. H., 1942, Geology and ore deposits of the Magdalena mining district, New Mexico: U. S. Geol. Surv., Prof. Paper 200, 168 p.

Olsen, K. H., Keller, G. R., and Stewart, J. N., 1979, Crustal structure along the Rio Grande rift from seismic refraction profiles: in Rio Grande Rift: Tectonics and Magmatism, ed. by R. E. Riecker: Amer. Geophysical Union, p. 127-143.

Reilinger, R. E., and Oliver, J. E., 1976, Modern uplift associated with a proposed magma body in the vicinity of Socorro, New Mexico: Geology, v. 4, p. 583-586.

Reiter, M., Edwards, C. L., Hartman, H., and Weidman, C., 1975, Terrestrial heat flow along the Rio Grande Rift, New Mexico and southern Colorado: Geol. Soc. Amer. Bull., v. 86, p. 811818 .

Reiter, M., and Smith, R., 1977, Subsurface temperature data in the Socorro Peak KGRA, New Mexico: Geothermal Energy Magazine, v. 5 , no. 10, p. $37-41$.

Rinehart, E. J., Sanford, A. R., and Ward, R. M., 1979, Geographic extent and shape of an extensive magma body at mid-crustal depths in the Rio Grande Rift near Socorro, New Mexico: in Rio Grande Rift: Tectonics and Magmatism, ed. by R. E. Riecker: Amer. Geophysical Union, p. 237-251.

Sanford, A. R., and Long, L. T., 1965, Microearthquake crustal reflections, Socorro, New Mexico: Bull. Seismol. Soc. Amer., v. 55, p. 579-586.

Sanford, A. R., Alptekin, O. S., and Toppozada, T. R., 1973, Use of reflection phases on microearthquake seismograms to map an unusual discontinuity beneath the Rio Grande Rift: Bull. Seismo1. Soc. Amer., v. 63, p. 2021-2034.

Sanford, A. R., Olsen, K. H., and Jaksha, L. H., 1979, Seismicity of the Rio Grande Rift: in Rio Grande Rift: Tectonics and Magmatism, ed. by R. E. Riecher: Amer. Geophysical Union, p. $145-168$.

Summers, W. K., 1976, Catalogue of thermal waters in New Mexico: New Mexico Bureau of Mines and Mineral Resources, Hydrologic Report 4, 80 p. 
JAMES B. KOENIG (415) 524-9242

MURRAY C. GARDNER (503) 482-2605

Summers, W. K., Schwab, G. E., and Brandvold, L. A., 1972, Groundwater characteristics in a recharge area, Magdalena Mountains, Socorro County, New Mexico: New Mexico Bureau of Mines and Mineral Resources, Circular 124, 18 p. 


\section{FIELD DATA SHEET TEMPERATURE SURVEY}

HOLE NUMBER B $B 9$ TD $249^{\prime}$

REFERENCE MAP $5-77$

REMARKS
HOLE NO. 89

RUN NO. 4 Atandoned

DATE 7.2777

TIME:

START 2:00 P.M

SENSOR SERIAL NO.

$3>6$

OPERATOR

Michael RGlascos

\begin{tabular}{|c|c|c|c|c|c|c|c|c|}
\hline$F T$ & $K \Omega$ & 0 & $F T$ & $K \Omega$ & oF & $F T$. & $K \Omega$ & OF \\
\hline 10 & 110.90 & 67.15 & 280 & & & 550 & & \\
\hline 20 & 119.94 & 64.26 & 290 & & & 560 & & \\
\hline 30 & 118.10 & 64.82 & 300 & & & 570 & & \\
\hline 40 & 116.43 & 65.35 & 310 & & & 580 & & \\
\hline 50 & 115.38 & 65.67 & 320 & & & 590 & & \\
\hline 60 & 114.28 & 66.03 & 330 & & & 600 & & \\
\hline 70 & 113.03 & 66.45 & 340 & & & 610 & & \\
\hline 80 & 111.81 & 66.85 & 350 & & & 620 & & \\
\hline 90 & 110.67 & 67.21 & 360 & & & 630 & & \\
\hline 100 & 109.46 & 67.62 & 370 & & & 640 & & \\
\hline 110 & 108.31 & 68.03 & 380 & & & 650 & & \\
\hline 120 & 107.15 & 68.41 & 390 & & & 660 & & \\
\hline 130 & 105.99 & 68.83 & 400 & & & 670 & & \\
\hline 140 & 104.87 & 69.22 & 410 & & & 680 & & \\
\hline 150 & 103.83 & 69.62 & 420 & & & 690 & & \\
\hline 160 & 102.70 & 70.02 & 430 & & & 700 & & \\
\hline 170 & 101.58 & 70.42 & 440 & & & 710 & & \\
\hline 180 & 100.46 & 70.83 & 450 & & & 720 & & \\
\hline 190 & 99.32 & 71.28 & 460 & & & 730 & & \\
\hline 200 & 98.22 & 71.70 & 470 & & & 740 & & \\
\hline 210 & 97.28 & 72.06 & 480 & & & 750 & & \\
\hline 220 & 96.39 & 72.41 & 490 & & & 760 & & \\
\hline 230 & 95.45 & 72.78 & 500 & & & 770 & & \\
\hline 240 & 94.52 & 73.15 & 510 & & & 780 & & \\
\hline 2490 & 9.93 .79 & 73.45 & 520 & & & 790 & & \\
\hline 260 & & & 530 & & & 800 & & \\
\hline 270 & & & 540 & & & 810 & & \\
\hline
\end{tabular}




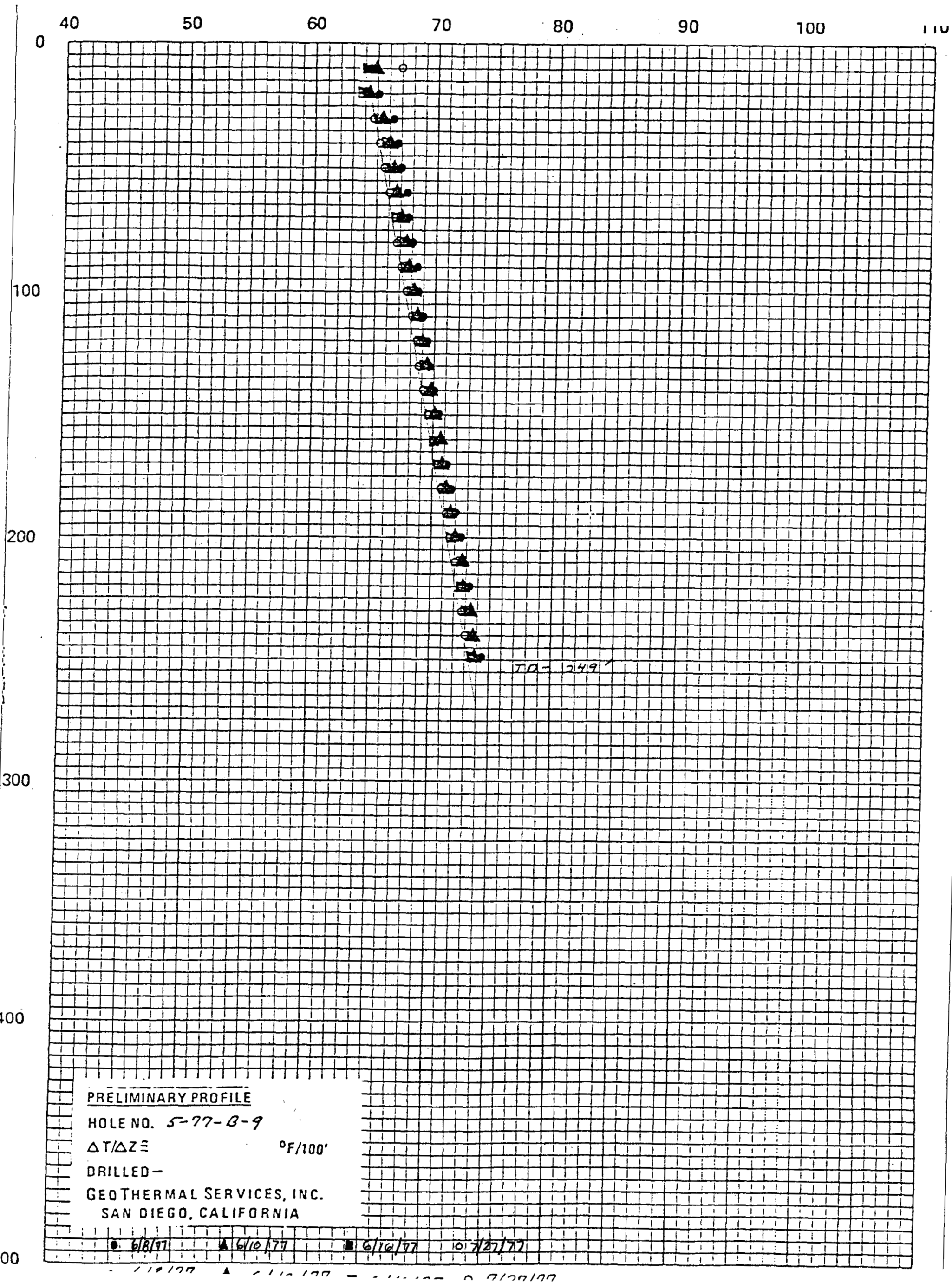


FIELD DATA BHEET

TEMPERATURE SURVEY

HOLE NUMBER_B REFERENCE MAP $5-77$

REMARKS
HOLE NO. 815

RUN NO. 4 Abandoerd

DATE $7-28 \cdot 7 z$

TIME:

START $10: 45$ A.M

END $1 \overline{1: 20 A M}$

SENSOR SERIAL NO. $3>6$

OPERATOR

Hichae?

\begin{tabular}{|c|c|c|c|c|c|c|c|c|}
\hline FT. & $K \Omega$ & OF & $F T$. & $k \Omega$ & ${ }^{0} F$ & FT. & $K \Omega$ & ${ }^{O F}$ \\
\hline 10 & 117.00 & 65.16 & 280 & & & 550 & & \\
\hline 20 & 123.31 & 63.23 & 290 & & & 560 & & \\
\hline 30 & 119.02 & 64.54 & 300 & & & 570 & & \\
\hline 40 & 116.89 & 65.19 & 310 & & & 580 & & \\
\hline 50 & 115.58 & 65.61 & 320 & & & 590 & & \\
\hline 60 & 114.49 & 65.96 & 330 & & & 600 & & \\
\hline 70 & 113.43 & 66.32 & 340 & & & 610 & & \\
\hline 80 & 112.62 & 66.58 & 350 & & & 620 & & \\
\hline 90 & .111 .74 & 66.88 & 360 & & & 630 & & \\
\hline 100 & 110.88 & 67.15 & 370 & & & 640 & & \\
\hline 110 & 109.97 & 67.45 & 380 & - & & 650 & & \\
\hline 120 & 109.15 & 67.72 & 390 & & & 660 & & \\
\hline 130 & 108.30 & 68.03 & 400 & & & 670 & & \\
\hline 140 & 107.46 & 68.31 & 410 & & & 680 & & \\
\hline 150 & 106.59 & 68.62 & 420 & & & 690 & · & \\
\hline 160 & 105.75 & 68.90 & 430 & & & 700 & & \\
\hline 170 & 104.97 & 69.19 & 440 & & & 710 & & \\
\hline 180 & 104.15 & 69.48 & 450 & & - & 720 & & \\
\hline 190 & 103.29 & 69.80 & 460 & & & 730 & & \\
\hline 200 & 10251 & 70.09 & 470 & & & 740 & & \\
\hline 210 & 101.77 & 70.35 & 480 & & & 750 & & \\
\hline 220 & 101.02 & 70.65 & 490 & & & $760^{\circ}$ & & \\
\hline 230 & 100.13 & 70.98 & 500 & & & 770 & & \\
\hline 240 & 99.33 & 71.28 & 510 & & & 780 & & \\
\hline 250 & 9850 & 71.59 & 520 & & & 790 & & \\
\hline 2607 & 0.97 .76 & 71.88 & 530 & & & 800 & & \\
\hline 270 & & & 540 & & & 810 & & \\
\hline
\end{tabular}




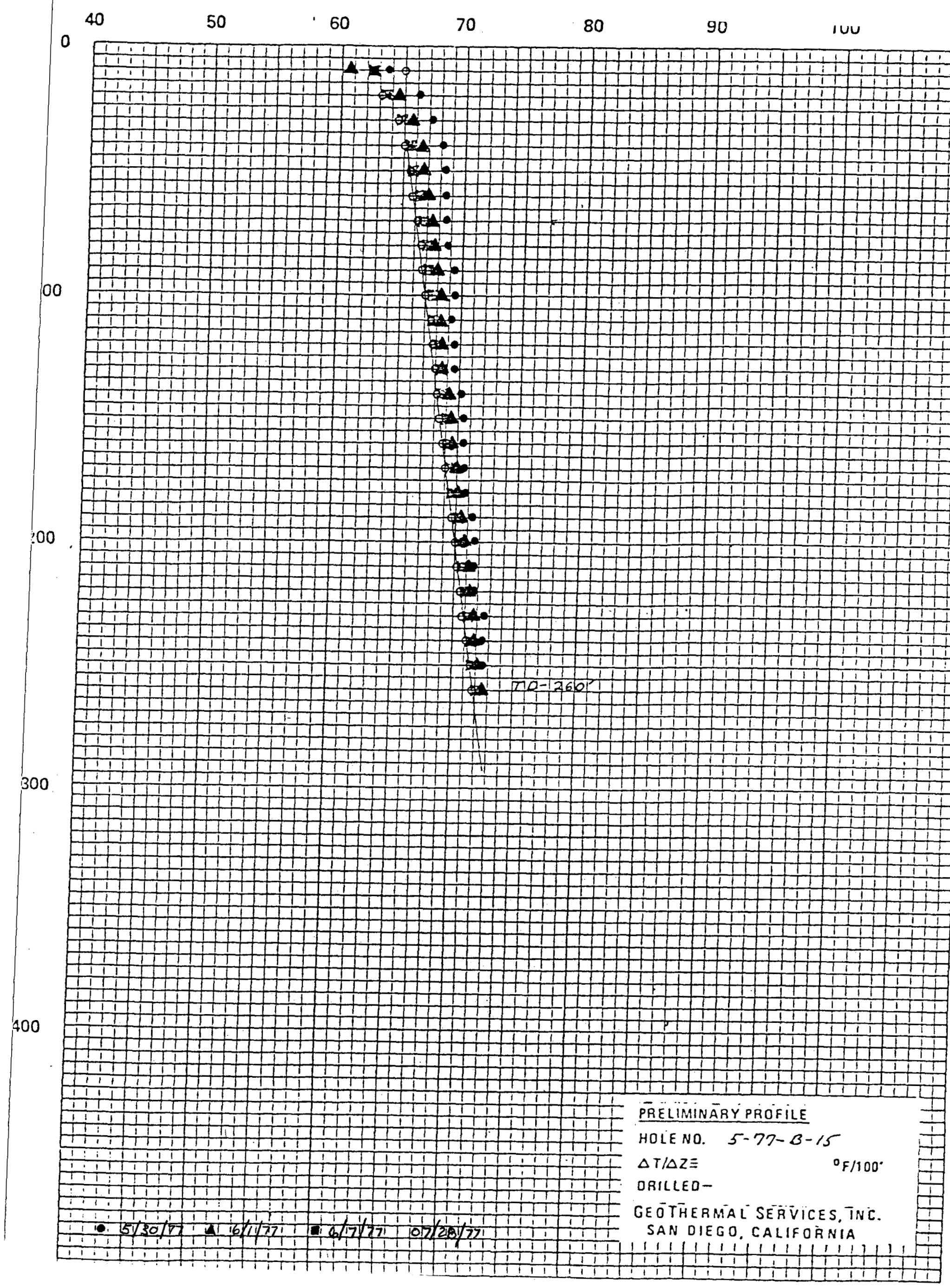


FIELD DATA BHEET

TEMPERATURE SURVEY

HOLE NUMBER $\frac{5-77 B / 5}{5-11}$ TD 380 '
REFERENCE MAP $\frac{5-17}{\text { REMARKS ABANSOUMENT SURUEY }}$

\begin{tabular}{|c|c|c|c|c|c|c|c|c|}
\hline FT. & $K \Omega$ & ${ }^{\circ F}$ & FT. & $K \Omega$ & ${ }^{a} F$ & FT. & $K \Omega$ & ${ }^{\circ} F$ \\
\hline 10 & 123.36 & 67.44 & 280 & 132.32 & 64.85 & 550 & . & \\
\hline 20 & 137.24 & 63.52 & 290 & 132.02 & 64.94 & 560 & & \\
\hline 30 & 141.72 & $\ln 2.35$ & 300 & 131.81 & 6498 & 570 & & \\
\hline 40 & 14109 & 62.51 & 310 & 131.46 & 65.08 & 580 & & \\
\hline 50 & 140.05 & 62.78 & 320 & 131.05 & 65.2 .1 & 590 & & \\
\hline 60 & 139.30 & 62.96 & 330 & 130.60 & 65.34 & 600 & & \\
\hline 70 & 138.69 & 63.14 & 340 & 130.25 & 65.43 & 670 & & \\
\hline 80 & 138.22 & $\ln 3.25$ & 350 & 129.88 & $65^{53}$ & 620 & & \\
\hline 90 & 137.11 & $\operatorname{lo} 3.39$ & 360 & 129.44 & 65.66 & 630 & & \\
\hline 100 & 137.48 & 63.45 & 370 & 128.82 & 65.84 & 640 & & \\
\hline 110 & 137.14 & 63.54 & 380 & 128.81 & 65.82 & 650 & & \\
\hline 120 & 136.88 & $\ln 3.61$ & 390 & & & 660 & & \\
\hline 130 & 136.12 & 63.64 & 400 & & & 670 & & \\
\hline 140 & 136.47 & 6.272 & 410 & & & 680 & & \\
\hline 150 & 136.19 & 63.79 & 420 & & & 690 & & \\
\hline 160 & 135.91 & 63.80 & 430 & & . & 700 & & \\
\hline 170 & 135.20 & $\ln 3.91$ & 440 & & & 710 & & \\
\hline 180 & 135.42 & 6400 & 450 & & & 720 & & \\
\hline 180 & 135.01 & 1.4 .09 & 460 & & & 730 & & \\
\hline 200 & 134.84 & 6417 & 470 & & & 740 & & \\
\hline 210 & 134.69 & 6400 & 480 & & & 750 & . & \\
\hline 220 & 134.24 & 64.33 & 490 & & & $760^{\circ}$ & & \\
\hline 230 & 134.04 & 6432 & 500 & & & 770 & & \\
\hline 240 & 133.75 & 64.45 & 510 & & & 780 & & \\
\hline 250 & 133.34 & 6456 & 520 & . & & 790 & & \\
\hline 200 & 132.91 & 6467 & 530 & & & 800 & & \\
\hline 270 & 132.15 & $647=1$ & 540 & & & 810 & & \\
\hline
\end{tabular}

PAGE 1 OF 


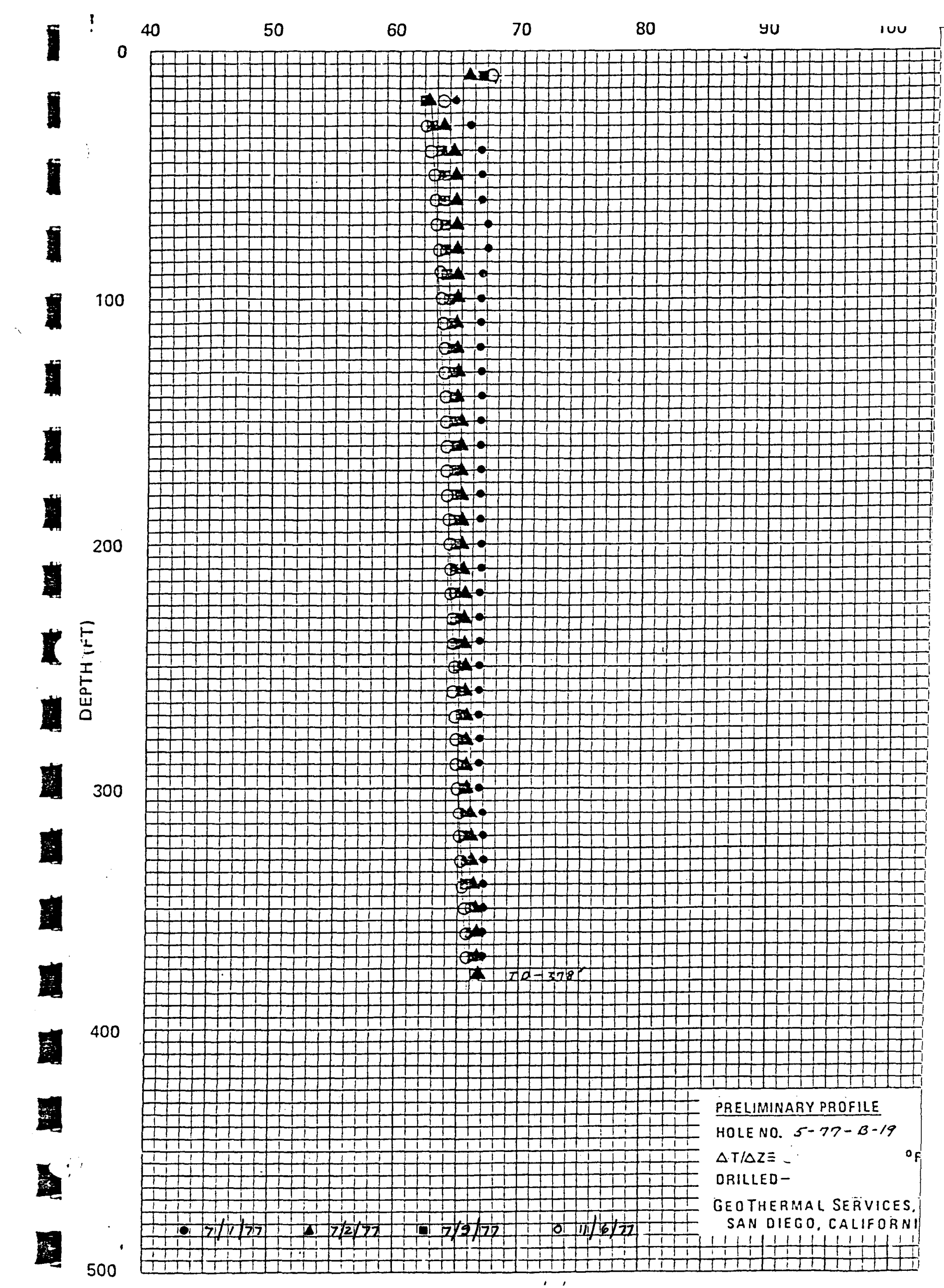


FIELD DATA BHETT

TEMPERATURE

SURVEY

HOLE NUMBER $5-77-320^{\circ}$ TD $240^{\prime}$

REFERENCE MAP $5-71$

REMARKS ABANDONMENT SUEVY
HOLE NO. $5-n-B 20$ RUN NO. $4 \cdot A B D$

DATE $1 / 16 / 21$

TIME:

START $\frac{11: 20}{11: 45}$

SENSOR SERIAL NO.

$\frac{2}{\text { OPERATOR }}$

OPERATOR MUSFAT

\begin{tabular}{|c|c|c|c|c|c|c|c|c|}
\hline$F T$. & $K \Omega$ & ${ }^{\circ} F$ & FT. & $K \Omega$ & ${ }^{\circ} F$ & FT. & $k \Omega$ & ${ }^{\circ F}$ \\
\hline 10 & 120.56 & 68.29 & 280 & & & 550 & & \\
\hline 20 & 124.63 & 61.06 & 290 & & & 560 & & \\
\hline 30 & 124.64 & 67.06 & 300 & & & 570 & & \\
\hline 40 & 121.37 & 68.04 & 310 & & & 580 & & \\
\hline 50 & 118.12 & 69.04 & 320 & & & 590 & & \\
\hline 60 & 115.27 & 69.96 & 330 & & & 600 & & \\
\hline 70 & 112.91 & 10.14 & 340 & & & 610 & & \\
\hline 80 & 109.75 & 71.80 & 350 & & & 620 & & \\
\hline 90 & 195.44 & 73.31 & 360 & & & 630 & & \\
\hline 100 & 102.48 & 74.39 & 370 & & & 640 & & \\
\hline 110 & 59.99 & 75.31 & 380 & & & 650 & & \\
\hline 120 & 98.12 & 75.81 & 390 & & & 660 & & \\
\hline 130 & 98.06 & 76.06 & 400 & & & 670 & & \\
\hline 140 & 91.40 & 76.32 & 410 & & & 680 & & \\
\hline 150 & 96.97 & 76.50 & 420 & & & 690 & & \\
\hline 160 & 96.55 & 76.64 & 430 & & & 700 & & \\
\hline 170 & 96.61 & 76.64 & 440 & & & 710 & & \\
\hline 180 & $55.8 t$ & 76.95 & 450 & & & 720 & & \\
\hline 100 & 94.54 & 27.31 & 460 & & & 730 & & \\
\hline 200 & 94.55 & 77.45 & 470 & & & 740 & & \\
\hline 210 & 93.61 & 77.81 & 480 & & & 750 & & \\
\hline 220 & 64.18 & 71.61 & 480 & & & 760 & & \\
\hline 230 & 93.19 & 78.01 & 500 & & & 770 & & \\
\hline 240 & 92.44 & 78.31 & 510 & & & 780 & & \\
\hline 250 & & & 520 & & & 790 & & \\
\hline 260 & & & 530 & & & 800 & & \\
\hline 270 & & & 540 & & & 810 & & \\
\hline
\end{tabular}




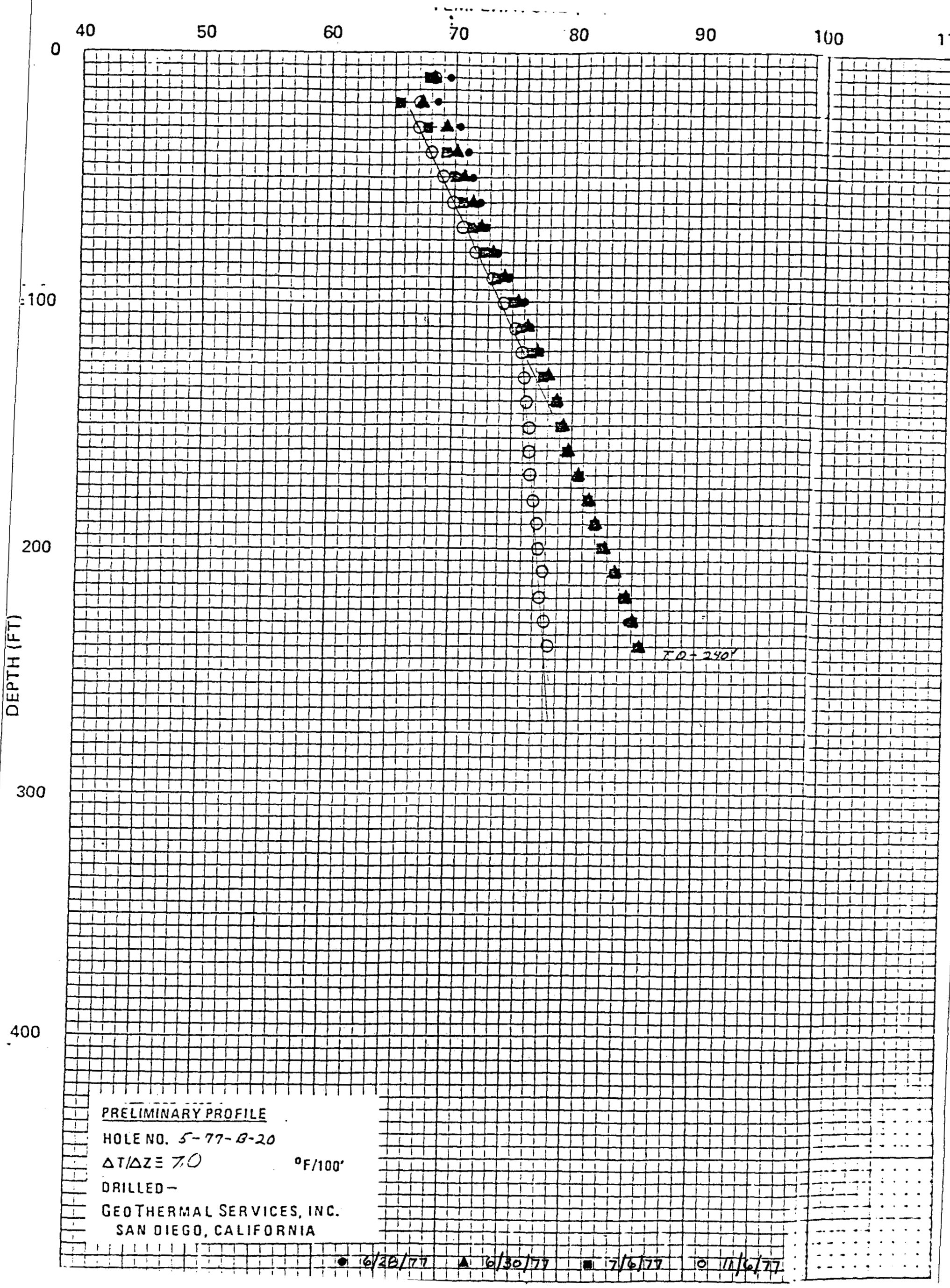




\section{FIELD DATA GHERT \\ TEMPERATURE SURVEY}

HOLE NUMBER: $5-71-B 21$ TD 380 REFERENCE MAP $5-71$

REMARKS ABANDONMENT SueVeY
HOLE NO. S-17-B21

RUN NO. $4-A B D$

DATE $1 / 10 / 71$

TIME: START $\frac{4: 00 \mathrm{PM}}{4: 35 \mathrm{PH}}$ SENSOR SERIAL NO. 2 OPERATOR TUDD MUSEAT

\begin{tabular}{|c|c|c|c|c|c|c|c|c|}
\hline$=T$. & $k \Omega$ & ${ }^{\circ} F$ & FT. & $k \Omega$ & ${ }^{a_{F}}$ & FT. & $K \Omega$ & ${ }^{D F}$ \\
\hline 10 & 132.60 & 64.78 & 280 & 144.55 & 61.52 & 550 & & \\
\hline 20 & $1+4.01$ & 61.75 & 290 & 144.63 & 61.59 & 560 & & \\
\hline 30 & 150.81 & 60.06 & 300 & 144.37 & 61.66 & 570 & & \\
\hline 40 & 151.01 & 60.04 & 310 & 144.19 & 6.72 & 580 & & \\
\hline 50 & 149.53 & 60.39 & 320 & 144.01 & 61.75 & 590 & & \\
\hline 60 & 148.50 & 60.64 & 330 & 14385 & 61.19 & 600 & & \\
\hline 70 & 147.87 & 60.80 & 340 & 143.63 & 61.80 & 610 & & \\
\hline 80 & 141.61 & 60.85 & 350 & 143.39 & 61.92 & 620 & & \\
\hline 90 & 147.26 & 60.54 & 360 & 143.91 & 61.11 & 630 & & \\
\hline 100 & 146.91 & 61.02 & 370 & 144.08 & 61.74 & 640 & & \\
\hline 1110 & 146.15 & $61.0 ?$ & 380 & 142.53 & 62.13 & 650 & & \\
\hline 120 & 146.56 & 61.12 & 390 & & & 680 & & \\
\hline 130 & 146.37 & 61.16 & 400 & & & 670 & & \\
\hline 140 & 14627 & 61.20 & 410 & & & 680 & & \\
\hline 150 & 145.58 & 61.27 & 420 & & & 690 & & \\
\hline 160 & 14618 & 61.21 & 430 & & & 700 & & \\
\hline 170 & 146.11 & 61.23 & 440 & & & 710 & & \\
\hline 180 & 145.96 & 61.27 & 450 & & & 720 & & \\
\hline 190 & 146.54 & 61.12 & 460 & & & 730 & & \\
\hline 200 & 146.50 & 61.12 & 470 & & & 740 & & \\
\hline 210 & 145.61 & 61.36 & 480 & & & 750 & & \\
\hline 220 & 145.53 & 61.38 & 490 & & & 760 & & \\
\hline 230 & 145.44 & 61.39 & 500 & & & 770 & & \\
\hline 240 & 145.36 & 61.41 & 510 & & & 780 & & \\
\hline 250 & 145.42 & 61.39 & 520 & & & 790 & & \\
\hline 260 & 145.17 & 61.47 & 530 & & & 800 & & \\
\hline 270 & 145.02 & 61.50 & 540 & & & 810 & & \\
\hline
\end{tabular}




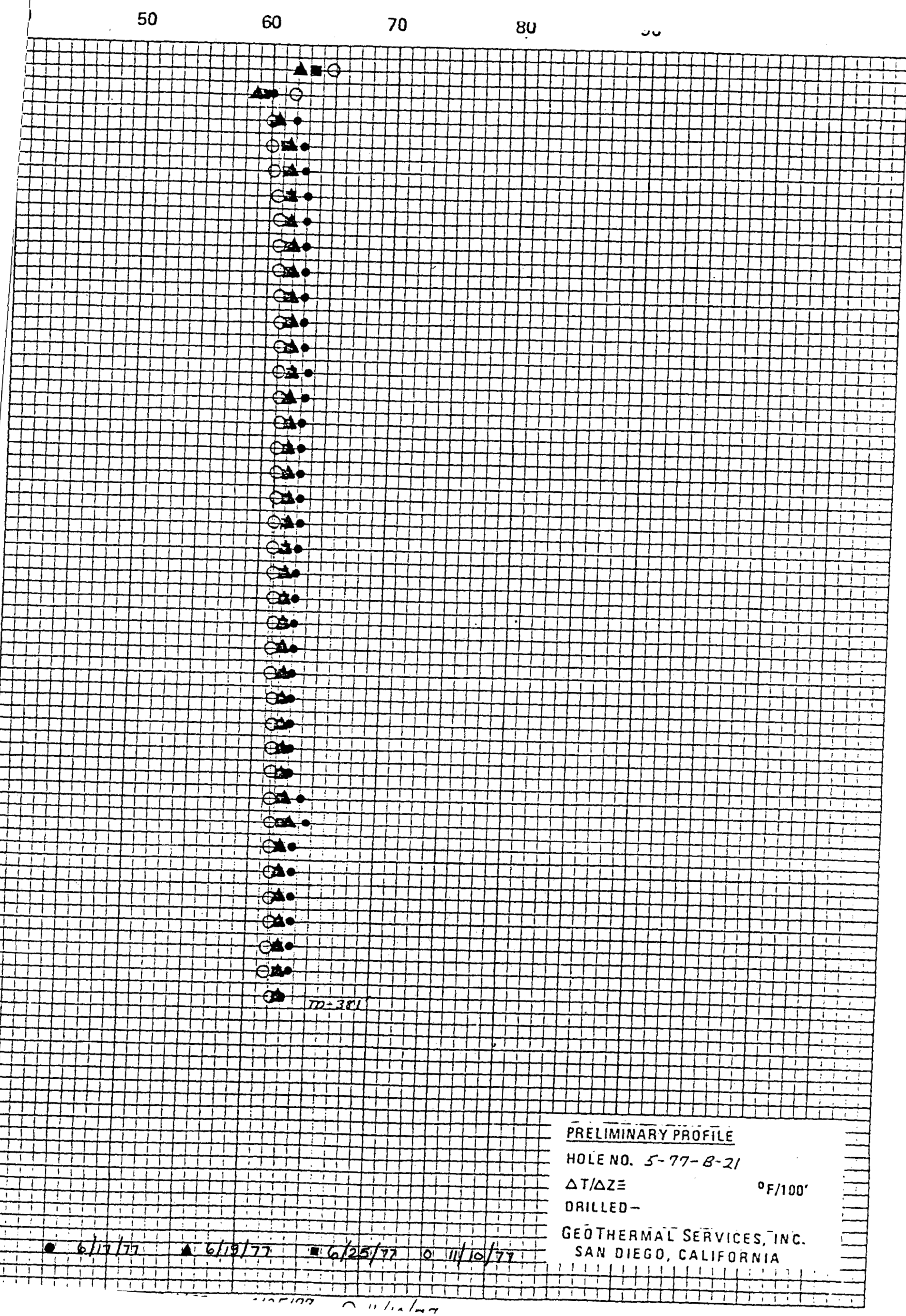


FIELD DATA BHET

TEMPERATURE SURVEY

hOLe NUMBer: $\frac{5-71-B_{-22}}{5-71}$ TD $61^{\prime}$ REFERENCE MAP $5-71$

REMARKS ABANDORTMENT SURVEY
HOLE NO. $\frac{5-n-B 22}{4-A B D}$

RUN NO. $4-A B D$

DATE 1.05

TIME:

START $\frac{11: 08}{11: 15}$

SENSOR ŞERIAL NO.

OPEAATOR

JUDD MUSKAT

\begin{tabular}{|c|c|c|c|c|c|c|c|c|}
\hline$F T$. & $k \Omega$ & ${ }^{\circ} F$ & FT. & $K \Omega$ & $a_{F}$ & FT. & $K \Omega$ & ${ }^{\circ} F$ \\
\hline 10 & 135.20 & 64.06 & 280 & & & 550 & & \\
\hline 20 & 143.07 & 61.99 & 290 & & & 560 & & \\
\hline 30 & 147.41 & 60.89 & 300 & & & 570 & & \\
\hline 40 & 148.44 & 60.66 & 310 & & & 580 & & \\
\hline 50 & 147.71 & 60.82 & 320 & & & 590 & & \\
\hline$-\infty 0_{01}$ & 146.79 & 61.05 & 330 & & & 600 & & \\
\hline 70 & TD. 6/1 & & 340 & & & 610 & & \\
\hline 80 & & & 350 & & & 620 & & \\
\hline 90 & & & 360 & & & 630 & & \\
\hline 100 & & . & 370 & & & 640 & & \\
\hline 110 & & & 380 & & & 650 & & \\
\hline 120 & & & 390 & & & 680 & & \\
\hline 130 & & & 400 & & & 670 & & \\
\hline 140 & & & 410 & & & 680 & & \\
\hline 150 & & & 420 & & & 690 & & \\
\hline 160 & & & 430 & & & 700 & & \\
\hline 170 & & & 440 & & & 710 & & \\
\hline 180 & & & 450 & & & 720 & & \\
\hline 180 & & & 460 & & & 730 & & \\
\hline 200 & & & 470 & & & 740 & & \\
\hline 210 & & & 480 & & & 750 & & \\
\hline 220 & & & 490 & & & 760 & & \\
\hline 230 & & & 500 & & & 770 & & \\
\hline 240 & & & 510 & & & 780 & & \\
\hline 250 & & & 520 & & & 790 & & \\
\hline 260 & & & 530 & & & 800 & & \\
\hline 270 & & & 540 & & & 810 & & \\
\hline
\end{tabular}



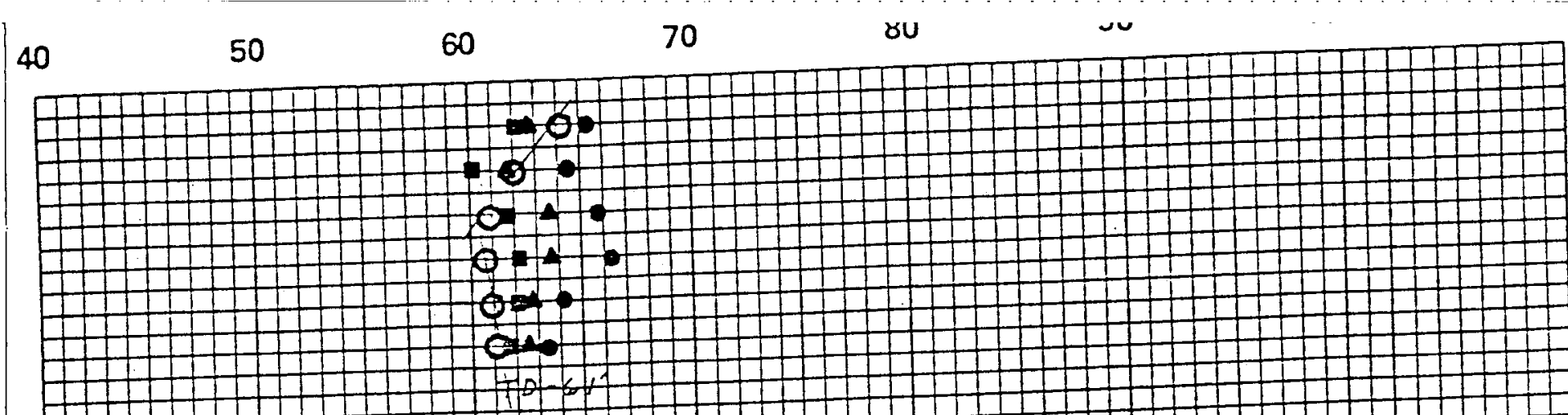

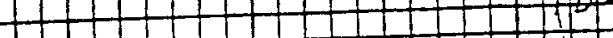

$$
\begin{array}{lllll}
\hline & & & & \\
\hline & & & & \\
\hline
\end{array}
$$$$
4+1+H+2 H
$$ 
FIELD DATA BHEET TEMPERATURE SURVEY

HOLE NUMBER: $5-77-\beta_{23}$ TD 3001 REFERENCE MAP $5-77$

REMARKS ABANDONMENT SURVEY
HOLE NO. $5-77-B_{23}$ RUN NO. $4-A B D$

DATE

TIME: START $\frac{9: 25 \mathrm{~cm}}{9: 55 \mathrm{am}}$ SENSOR SERIAL NO. $z$ OPERATOR

IUDD MUSFAT

\begin{tabular}{|c|c|c|c|c|c|c|c|c|}
\hline$=T$. & $K \Omega$ & OF & $F T$. & $K \Omega$ & ${ }^{\circ} F$ & FT. & $K \Omega$ & ${ }^{\circ} F$ \\
\hline 10 & 135.92 & 63.86 & 280 & 129.48 & 65.64 & 550 & & \\
\hline 20 & 146.15 & 62.21 & 290 & 128.56 & 65.91 & 560 & & \\
\hline 30 & 151.28 & 59.97 & 300 & 127.84 & 66.11 & 570 & & \\
\hline 40 & 150.10 & 60.26 & 310 & & & 580 & & \\
\hline 50 & 148.19 & 60.13 & 320 & & & 590 & & \\
\hline$\infty$ & 147.02 & 61.00 & 330 & & & 600 & & \\
\hline 70 & 146.13 & 61.23 & 340 & & & 610 & & \\
\hline 80 & 145.27 & 61.45 & 350 & & & 620 & & \\
\hline 90 & 144.46 & 61.39 & 360 & & & 630 & & \\
\hline 100 & 143.70 & 61.84 & 370 & & & 640 & & \\
\hline 110 & 143.00 & $62 . \%$ & 380 & & & 650 & & \\
\hline 120 & 142.19 & 62.22 & 390 & & & 660 & & \\
\hline 130 & 141.38 & 6244 & 400 & & & 670 & & \\
\hline 140 & 140.64 & 62.62 & 410 & & & 680 & & \\
\hline 150 & 13981 & 62.82 & 420 & & & 690 & & \\
\hline 160 & 139.06 & 63.03 & 430 & & & 700 & & \\
\hline 170 & 138.31 & 63.23 & 440 & & & 710 & & \\
\hline 180 & 137.66 & 63.41 & 460 & & & 720 & & \\
\hline 100 & 136.40 & 63.61 & 460 & & & 730 & & \\
\hline 200 & 36.18 & 63.81 & 470 & & & 740 & & \\
\hline 210 & 135.41 & 63.99 & 480 & & & 750 & & \\
\hline 220 & 134.63 & 64.22 & 490 & & & 760 & & \\
\hline 230 & 133.77 & 64.45 & 500 & & & 770 & & \\
\hline 240 & 13283 & $64: 71$ & 510 & & & 780 & & \\
\hline 250 & 131.96 & $64: 90$ & 520 & & & 790 & & \\
\hline 260 & 131.18 & 65.17 & 530 & & & 800 & & \\
\hline 270 & 130.34 & 65.41 & 540 & & & 810 & & \\
\hline
\end{tabular}




\section{FIELD DATA BHEET \\ TEMPERATURE SURVEY}

HOLE NUMBER $5.77-F_{1}$ TD $320^{\prime}$ REFERENCE MAP $5-7$

REMARKS ABANDOUMENT SUEVEY
HOLE NO. S-77-F,

RUN NO. 3-ABD

DATE $1 / / / 11$

TIME:

START 2:50

END $3: 20$

SENSOR SERIAL NO. 2

OPEPATOR

\begin{tabular}{|c|c|c|c|c|c|c|c|c|}
\hline$=T$. & $K \Omega$ & ${ }^{\circ} F$ & FT. & $K \Omega$ & ${ }^{a_{F}}$ & FT. & $K \Omega$ & ${ }^{\circ} F$ \\
\hline 10 & 134.14 & 64.35 & 280 & 125.26 & 66.87 & 550 & & \\
\hline 20 & 138.78 & 63.10 & 290 & 124.58 & 61.08 & 560 & & \\
\hline 30 & 143.82 & 61.81 & 300 & 123.74 & 61.32 & 570 & & \\
\hline 40 & 145.61 & 61.36 & 310 & 122.91 & 67.55 & 580 & & \\
\hline 50 & 144.47 & 61.65 & 320 & 122.33 & 67.75 & 590 & & \\
\hline$\infty$ & 142.95 & 62.02 & 330 & & & 600 & & \\
\hline 70 & 141.88 & 62.29 & 340 & & & 610 & & \\
\hline 80 & 140.83 & 62.56 & 350 & & & 620 & & \\
\hline 90 & 139.70 & 62.85 & 360 & & & 630 & & \\
\hline 100 & 13.14 & 63.01 & 370 & & & 640 & & \\
\hline 110 & 138.01 & 63.30 & 380 & & & 650 & & \\
\hline 120 & 137.32 & 63.48 & 390 & & & 880 & & \\
\hline 130 & 136.54 & 63.70 & 400 & & & 670 & & \\
\hline 140 & 135.89 & 63.88 & 410 & & & 680 & & \\
\hline 150 & 135.01 & 6411 & 420 & & & 690 & & \\
\hline 180 & 134.21 & 64.31 & 430 & & . & 700 & & \\
\hline 170 & 133.52 & 64.53 & 440 & & & 710 & & \\
\hline 180 & 132.56 & 64.78 & 450 & & & 720 & & \\
\hline 190 & 131.52 & 64.96 & 460 & & & 730 & & \\
\hline 200 & 131.22 & $65 \cdot 16$ & 470 & & & 740 & & \\
\hline 210 & 130.80 & 65.28 & 480 & & & 750 & & \\
\hline 220 & 130.10 & 65.48 & 480 & & & 760 & & \\
\hline 230 & 129.53 & .65 .64 & 500 & & & 770 & & \\
\hline 240 & 128.69 & 65.88 & 510 & & & 780 & & \\
\hline 250 & 12786 & 66.11 & 520 & & & 790 & & \\
\hline 260 & 126.65 & 66.47 & 530 & & & 800 & & \\
\hline 270 & 125.82 & 66.70 & 540 & & & 810 & & \\
\hline
\end{tabular}




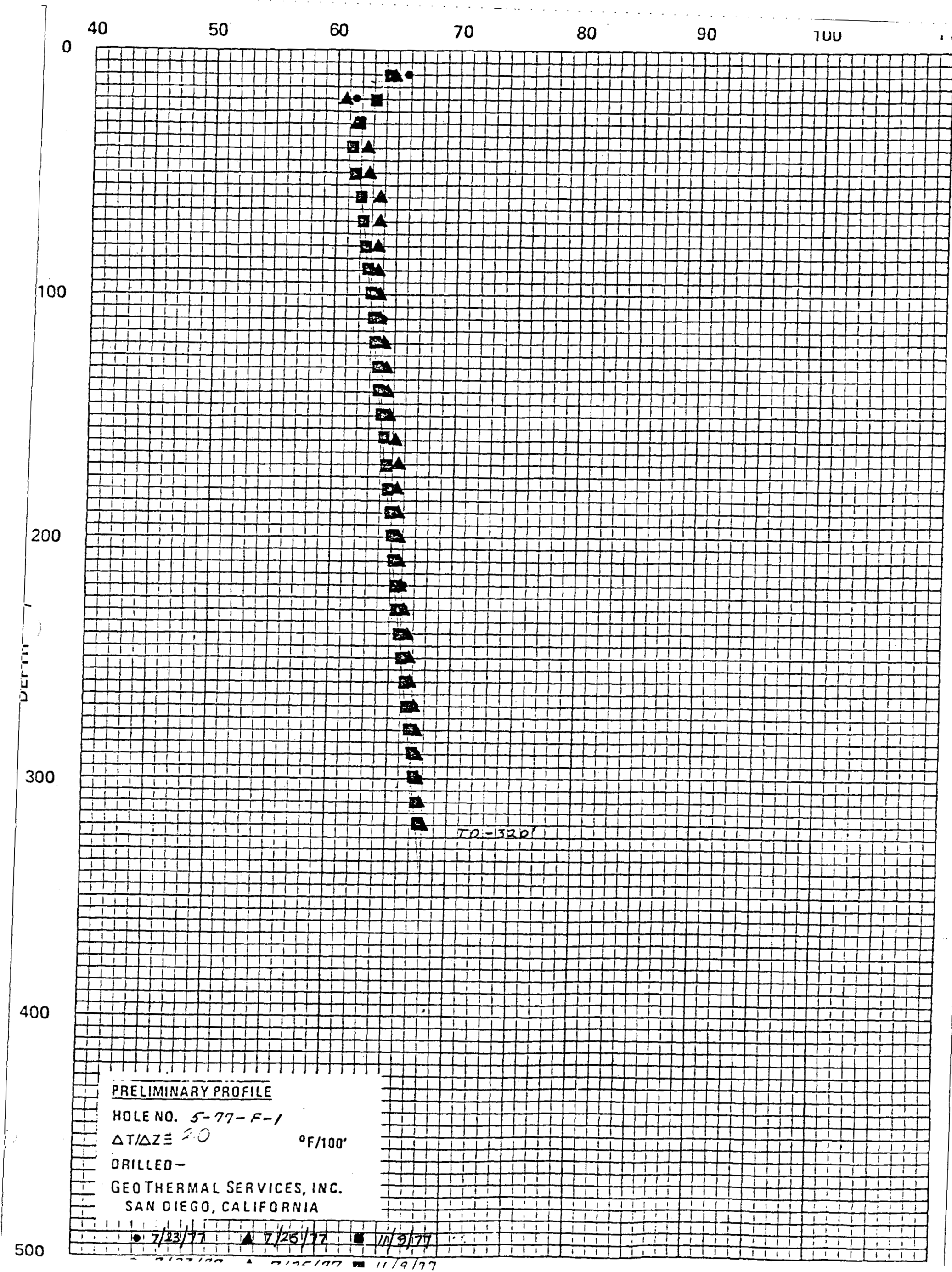


FIELD DATA BHEET

TEMPERATURE SURVEY

HOLe NUMBER: $5-77-F_{3}$ To $286^{\prime}$ REFERENCE MAP $5-71$

remarks Alandounhent Suevey
HOLE NO. $5-72-F 3$ RUN NO. $3-A B D$

DATE M/C/11

TIME: START $\frac{1: 25}{1: 55}$ SENSOR SERIAL NO. OPERATOR JNDDMUSKAT

\begin{tabular}{|c|c|c|c|c|c|c|c|c|}
\hline $\mathrm{T}$. & $K \Omega$ & ${ }^{\circ} F$ & FT. & $K \Omega$ & ${ }^{\circ} \mathrm{F}$ & FT. & $k \Omega$ & ${ }^{\circ} \mathrm{F}$ \\
\hline ? & 142.76 & 62.08 & 280 & 136.06 & 63.82 & 550 & & \\
\hline 5 & 149.23 & 60.46 & 290 & 135.82 & 63.82 & 560 & & \\
\hline 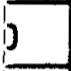 & 153.31 & 5949 & 300 & $286^{\prime} T . D$. & & 570 & & \\
\hline 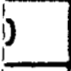 & 155.50 & 5898 & 310 & & & 580 & & \\
\hline 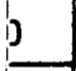 & $154 \cdot 18$ & 59.29 & 320 & & & 590 & & \\
\hline 2 & 152.21 & 59.63 & 330 & & & 600 & & \\
\hline 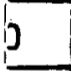 & 151.19 & 5999 & 340 & & & 610 & & \\
\hline 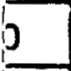 & 149.71 & 60.33 & 350 & & & 620 & & \\
\hline 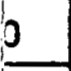 & 148.24 & 60.71 & 360 & & & 630 & & \\
\hline 0 & 146.84 & 60.80 & 370 & & & 640 & & \\
\hline 0 & 146.23 & 61.20 & 380 & & & 650 & & \\
\hline 0 & 145.70 & 61.34 & 390 & & & 680 & & \\
\hline 30 & 144.45 & 61.65 & 400 & & & 670 & & \\
\hline 10 & 143.76 & 61.83 & 410 & & & 680 & & \\
\hline 50 & 143.42 & 61.50 & 420 & & & 690 & & \\
\hline 50 & 142.74 & 62.08 & 430 & & & 700 & & \\
\hline 10 & 142,18 & 62.22 & 440 & & & 710 & & \\
\hline 30 & 141.66 & 62.35 & 450 & & & 720 & & \\
\hline 30 & 141.12 & 62.43 & 460 & & & 730 & & \\
\hline 0 & 140.62 & 62.62 & 470 & & & 740 & & \\
\hline 10 & 140.02 & 62.78 & 480 & & & 750 & & \\
\hline 20 & 139.40 & 62.94 & 490 & & & 760 & & \\
\hline 30 & 138.83 & 63.09 & 500 & & & 770 & & \\
\hline 10 & 138.23 & 63.25 & 510 & & & 780 & & \\
\hline 50 & 137.69 & 63.39 & 520 & & & 790 & & \\
\hline$\infty$ & 137.12 & 63.54 & 530 & & & 800 & & \\
\hline 0 & 136.59 & 63.68 & 540 & & & 810 & & \\
\hline
\end{tabular}




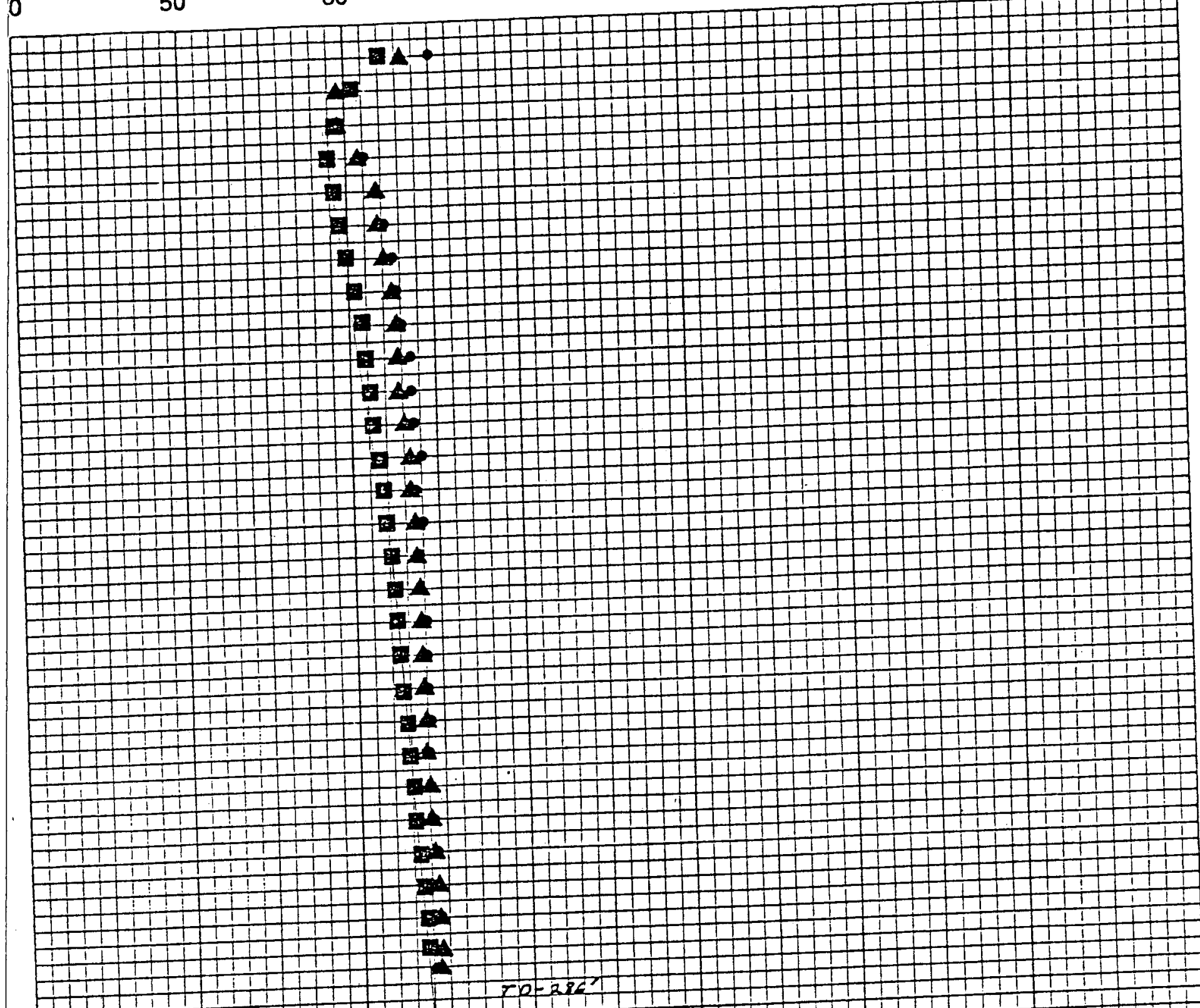

$20-286$

+1 $1+1+11$

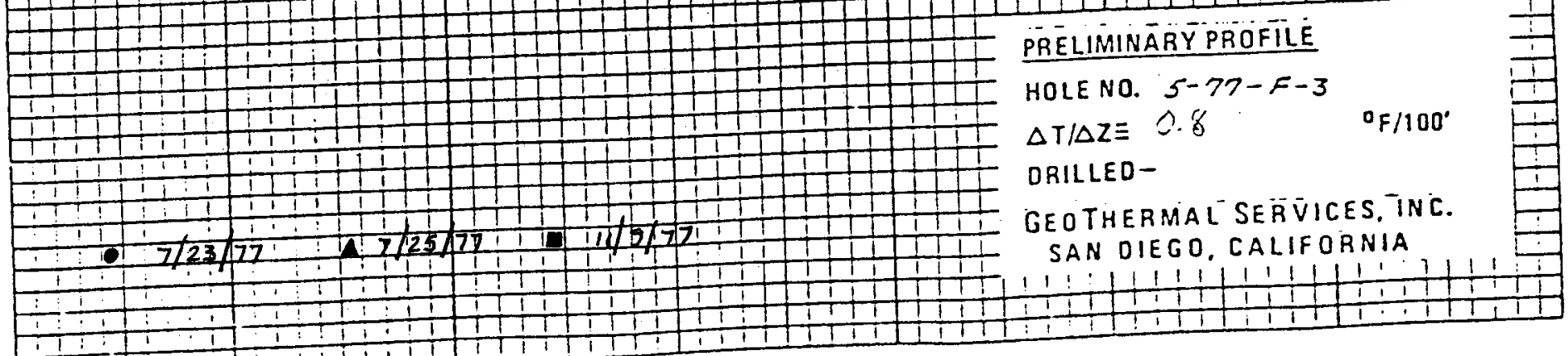


FIELD DATA OHEET

TEMPERATURE SURVEY

HOLe NUMBer: $5-71-F 4$ TD $315^{\prime}$

REFERENCE MAP $5-71$

REMARKS ABANDOUMENT SURVEY
HOLE NO. S-17-Fy

RUN NO. $4-A B D$

DATE /1/2/17

TIME:

START $11.50 \mathrm{am}$

END $12: 15$

SENSOR SERIAL NO.

$\frac{2}{\text { OPERATOR }}$

TUDD MUSAT

\begin{tabular}{|c|c|c|c|c|c|c|c|c|}
\hline r. & $K \Omega$ & ${ }^{\circ F}$ & FT. & $k \Omega$ & ${ }^{\circ} F$ & FT. & $K \Omega$ & ${ }^{\circ} F$ \\
\hline & 138.21 & 63.25 & 280 & 141.45 & 62.10 & 550 & & \\
\hline & 149.93 & 60.30 & 290 & 140.91 & 62.53 & 560 & & \\
\hline & 155.86 & 58.89 & 300 & 140.41 & 62.67 & 570 & & \\
\hline & 156.25 & 5880 & 310 & 139.94 & 6280 & 580 & & \\
\hline & 154.58 & 59.20 & 320 & 139.20 & 62.87 & 590 & & \\
\hline & 153.08 & 59.54 & 330 & $315+0$. & & 600 & & \\
\hline & 151.91 & 59.83 & 340 & & & 610 & & \\
\hline & 151.12 & 60.01 & 350 & & & 620 & & \\
\hline & 150.48 & 60.17 & 360 & & & 630 & & \\
\hline 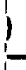 & 149.84 & 60.31 & 370 & & & 640 & & \\
\hline 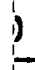 & 145.29 & 60.46 & 380 & & & 650 & & \\
\hline 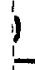 & 14854 & 60.64 & 390 & & & 680 & & \\
\hline 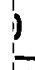 & 147.85 & 60.80 & 400 & & & 670 & & \\
\hline 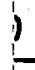 & 17.48 & 60.89 & 410 & & $\cdot$ & 680 & & \\
\hline$!$ & 147.18 & 60.96 & 420 & & & 690 & & \\
\hline & 146.78 & 61.07 & 430 & & & 700 & & \\
\hline & 146.49 & 61.14 & 440 & & & 710 & & \\
\hline & 146.08 & 61.23 & 450 & & & 720 & & \\
\hline & 145.64 & 61.34 & 460 & & & 730 & & \\
\hline & 145.21 & 61.45 & 470 & & & 740 & & \\
\hline & $1+4.81$ & 61.56 & 480 & & & 750 & & \\
\hline & 144.37 & 61.65 & 490 & & & $760^{\circ}$ & & \\
\hline & 143.86 & 61.79 & 500 & & & 770 & & \\
\hline & 143.38 & 61.88 & 510 & & & 780 & & \\
\hline & 142.98 & 62.02 & 520 & & & 790 & & \\
\hline & 142.54 & 62.13 & 530 & & & 800 & & \\
\hline & 141.91 & 62.28 & 540 & & & 810 & & \\
\hline
\end{tabular}




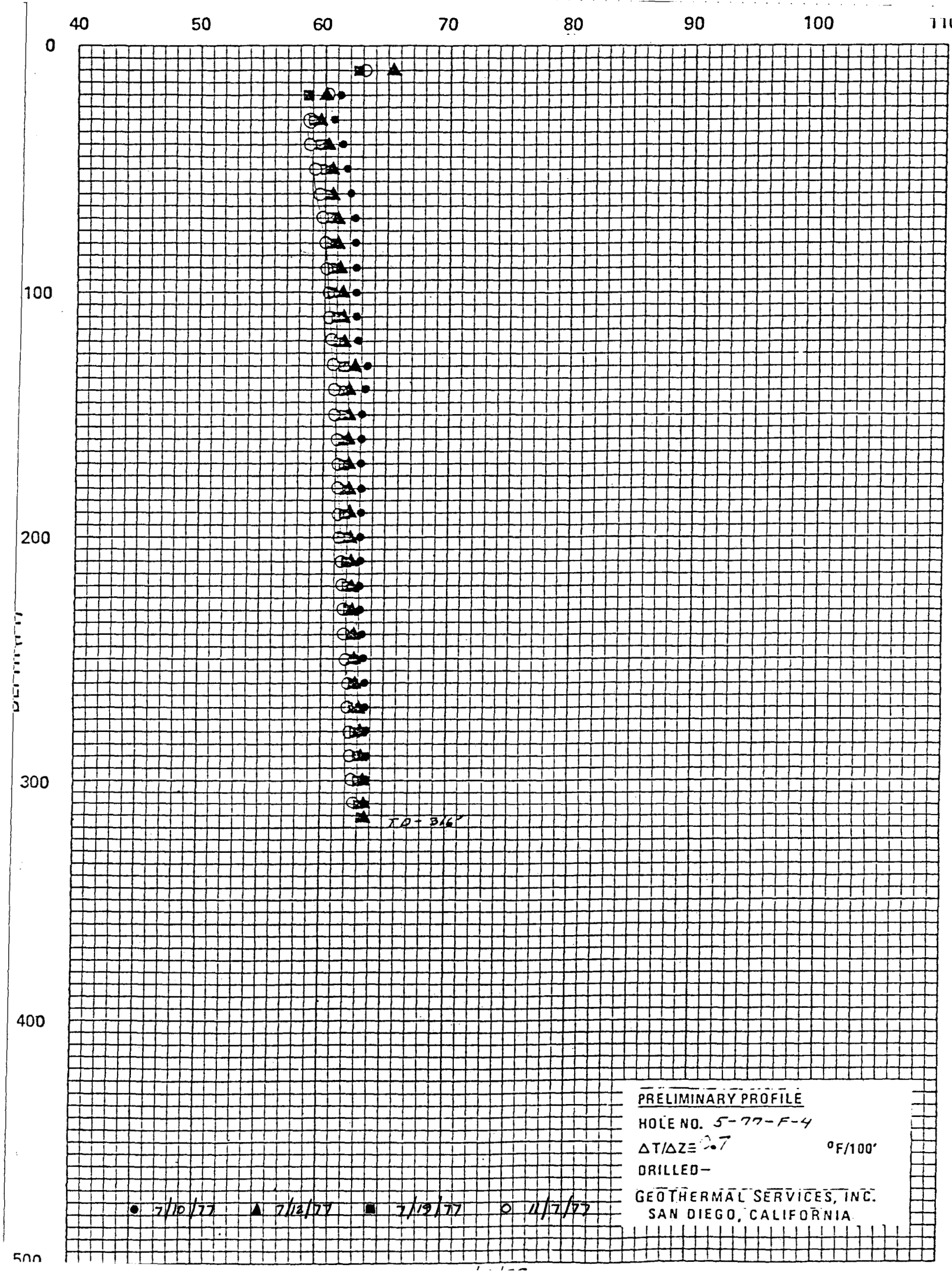




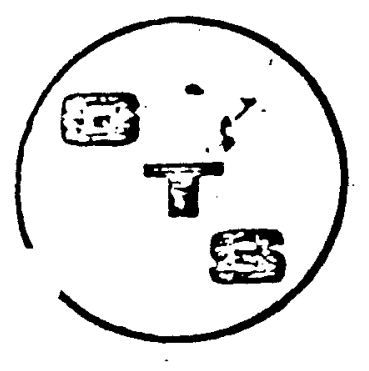

fiEld DATA EHETT

TEMPERATURE
SURVEY

HOLE NUMBER P. $P .30$ TD $420^{\prime}$

REFERENCE MAP

$1-78$

REMARKS

HOLE NO. $P: 0$

RUN NO. .3

DATE $4 / 1: 178$

TIME:

START 1345

END 1500

SENSOR SERIAL NO.

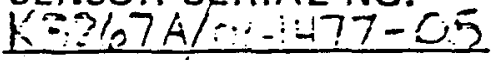
OPERATÓR

O(A) 20.1 .

\begin{tabular}{|c|c|c|c|c|c|c|c|c|}
\hline$F T$. & $K \Omega$ & 口F & FT. & $\kappa \Omega$ & ${ }^{\circ} \mathrm{F}$ & FT. & $k \Omega$ & ${ }^{O} F$ \\
\hline 10 & 1712.07 & $60.2 E$ & 280 & 139.69 & $\ln 8,74$ & 550 & & \\
\hline 20 & 164.68 & 62.60 & 290 & 138.75 & 68.99 & 560 & & \\
\hline 30 & 158,37 & 164,09 & 300 & 137.84 & 100.23 & 570 & & \\
\hline 40 & 157.53 & 64,24 & 310 & $137.14^{\prime}$ & 69,42 & 580 & & \\
\hline 50 & 157.25 & 64,35 & 320 & 136,43 & 160,62 & 590 & & \\
\hline$\infty 0$ & 156,46 & 64,54 & 330 & 135.78 & 69.80 & 600 & & \\
\hline 70 & $155: 16$ & 64.85 & 340 & 135.23 & 69.94 & 610 & & \\
\hline 80 & 154.57 & 65.610 & 350 & 13.3 .8 .5 & 70.33 & 620 & & \\
\hline 90 & $155.1 \%$ & 64.84 & 360 & 133.34 & 70.50 & 630 & & \\
\hline 100 & 124,33 & $\therefore 5.05$ & 370 & 132.48 & 70,72 & 640 & & \\
\hline 110 & $15,3, \%$ ind & $(m, 6)$ & 380 & 131.71 & 70.93 & 650 & & \\
\hline 120 & 152.63 & 65.44 & 390 & 120.99 & 71.14 & 660 & & \\
\hline 130 & 151.86 & 63.64 & 400 & 130,34 & 71.33 & 670 & & \\
\hline 140 & 150.105 & 65.93 & 410 & 129.40 & 71,60 & 680 & & \\
\hline 150 & 140,95 & 66,10 & 420 & 128,81 & 71.78 & 690 & & \\
\hline 160 & 149.09 & 66.39 & 130 & & & 700 & & \\
\hline 170 & $14 \%, 67$ & 66.42 & 440 & & & 710 & & \\
\hline 180 & 148.05 & 66,58 & 460 & & & 720 & & \\
\hline 100 & 147.04 & 618.83 & 460 & & & 730 & & \\
\hline 200 & 1410,31 & 67.01 & 470 & & & 740 & & \\
\hline 210 & 145.29 & 67.28 & 480 & & & 750 & & \\
\hline 220 & 144.19 & 67.42 & 490 & & & $760^{\circ}$ & & \\
\hline 230 & 143.77 & 67.107 & 500 & & & 770 & & \\
\hline 240 & 143.28 & 67.79 & 510 & & & 780 & & \\
\hline 50 & 142,36 & 68.04 & 520 & & & 790 & & \\
\hline 260 & 141.44 & 68.27 & 530 & & & 800 & & \\
\hline 270 & 140.54 & 68.51 & 540 & & & 810 & & \\
\hline
\end{tabular}




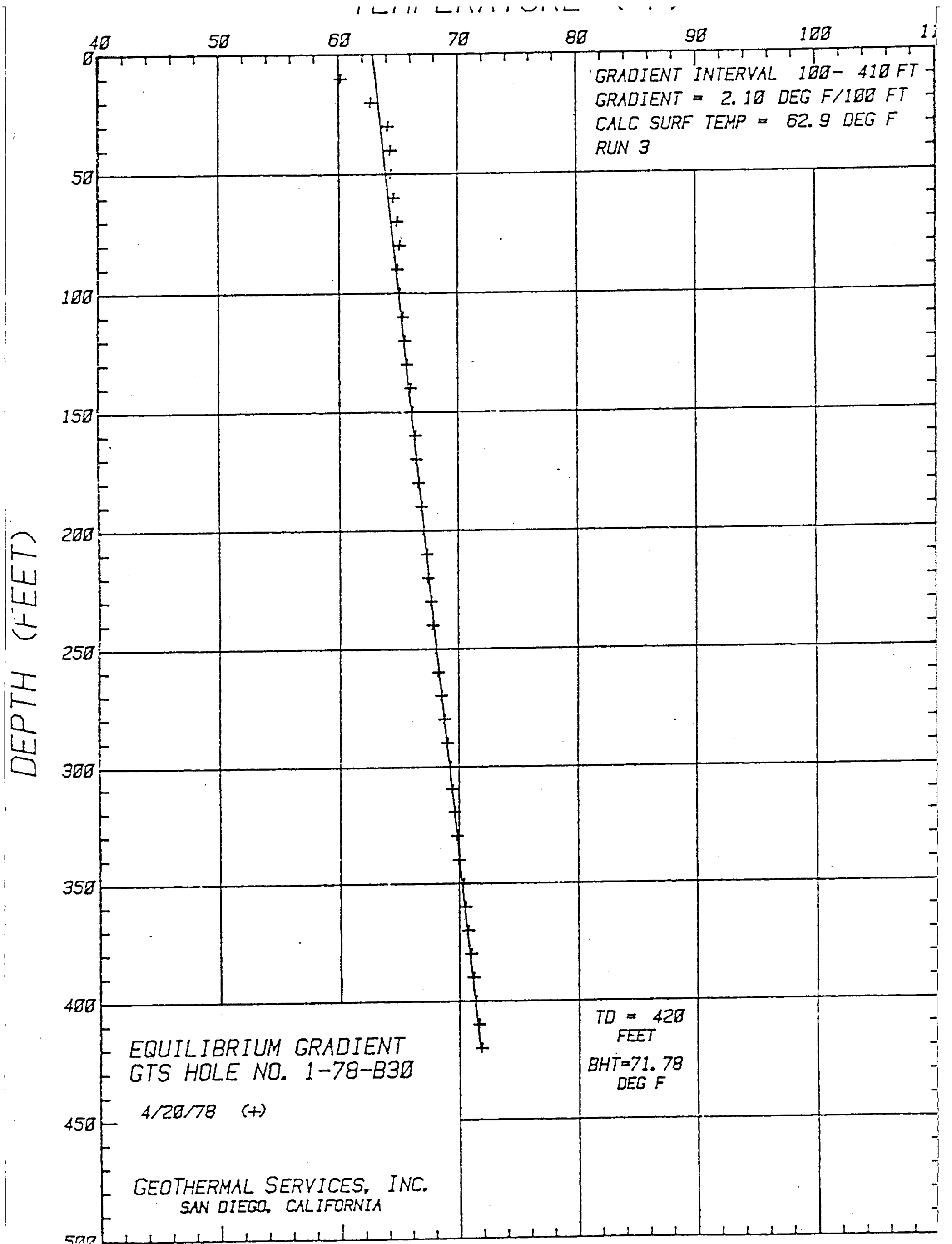




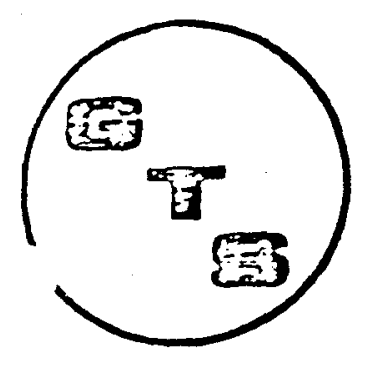

FIELD DATA BHEET TEMPERATURE
SURVEY

HOLE NUMBER $\overline{\tau_{i}} .71$ TD REFERENCE MAP $1-78$

REMARKS P!PG G' 29,' $315^{\prime}$
HOLE NO. $\because-z 1$

RUN NO. ?

DATE $\because 22175$

TIME:

START 1430

END 1540

SENSOR SERIAL NO.

$\because \because-A$ IMI-1S77-OS

OPERATOR

UWEA

\begin{tabular}{|c|c|c|c|c|c|c|c|c|}
\hline$F T$. & $K \Omega$ & OF & FT. & $K \Omega$ & ${ }^{\circ F}$ & FT. & $K \Omega$ & ${ }^{\circ} F$ \\
\hline 10 & 171.87 & $(r 1.1)$ & 280 & $1=0, n, 11$ & 1.9 .1 .9 & 550 & & \\
\hline 20 & $150,5)$ & 10.3 .82 & 290 & 135.14 & 1.9 .97 & 560 & & \\
\hline 30 & $15: 3$ & 105.98 & 300 & 134,57 & $70 ; .13$ & 570 & & \\
\hline 40 & 155.89 & 104.1 .7 & 310 & 133.56 & 70.33 & 580 & & \\
\hline 50 & 155.15 & 6490 & 320 & 132,84 & 70.61 & 590 & & \\
\hline$\infty$ & $1: 8,64$ & 64.99 & 330 & 122.07 & 70.83 & 600 & & \\
\hline 70 & $15 \div .00$ & $1,5,12$ & 340 & 131.35 & 71.04 & 610 & & \\
\hline 80 & $15 \div \therefore 4$ & 6.5 .23 & 350 & 130.32 & 71,24 & 620 & & \\
\hline 90 & 152.96 & $\ln 5.37$ & 360 & 129.27 & 71.1 .4 & 630 & & \\
\hline 100 & 152.06 & $6+5.54$ & 370 & $12 \pi .50$ & 71,87 & 640 & & \\
\hline 110 & $1=1, \therefore$ & $\because=5.71$ & 380 & 137.67 & 72.11 & 650 & & \\
\hline 120 & 151.02 & $6,5,84$ & 390 & $1: 10.94$ & 72.10 & 680 & & \\
\hline 130 & $15 r=3$ & $1 \cdot 1,01$ & 400 & 125.75 & 72,108 & 670 & & \\
\hline 140 & 147,90 & intor.36 & 410 & 125.13 & 72.87 & 680 & & \\
\hline 150 & $148.5 \%$ & $\sin 44$ & 420 & 124.15 & 73.17 & 690 & & \\
\hline 160 & 147.76 & 60.75 & 430 & 123.30 & 73.42 & 700 & & \\
\hline 170 & $1 \div \ln , 75$ & $B+90$ & 440 & 122.19 & $73.1 \div ?$ & 710 & & \\
\hline 180 & $101=7 \%$ & $\ln 7.15$ & 450 & 121.71 & $73.4 \%$ & 720 & & \\
\hline 190 & 145.139 & 107.20 & 460 & 120.96 & 74,110 & 730 & & \\
\hline 200 & 144,10 & 67.58 & 470 & $120,0 x$ & 74.43 & 740 & & \\
\hline 210 & 103.15 & 67.82 & 480 & 119.44 & 74,64 & 750 & & \\
\hline 220 & 142.01 & $69,1 i$ & 480 & $11 \bar{x} .56$ & 74.91 & 760 & & \\
\hline 230 & 140,97 & ins 40 & 500 & $11 \%, 00$ & 75.16 & 770 & & \\
\hline 240 & 100.08 & $1+x, n_{1}=$ & 510 & & & 780 & & \\
\hline 250 & $1=0.10$ & $1.5,-7$ & 520 & & & 790 & & \\
\hline 260 & 128.14 & $11^{9} .15$ & 530 & & & 800 & & \\
\hline 270 & $i=-9,0=$ & $\therefore 0.40$ & 540 & & & 810 & & \\
\hline
\end{tabular}




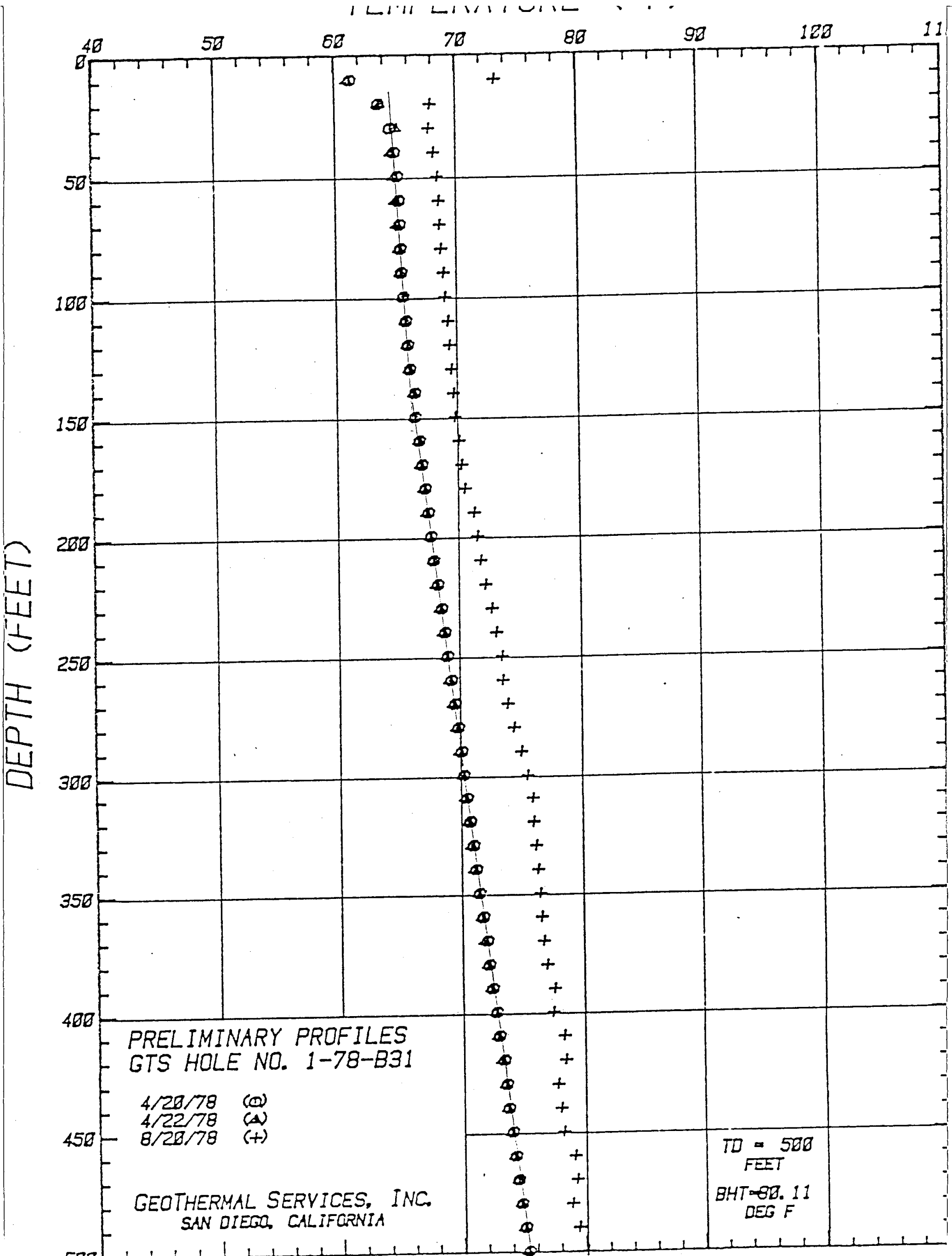




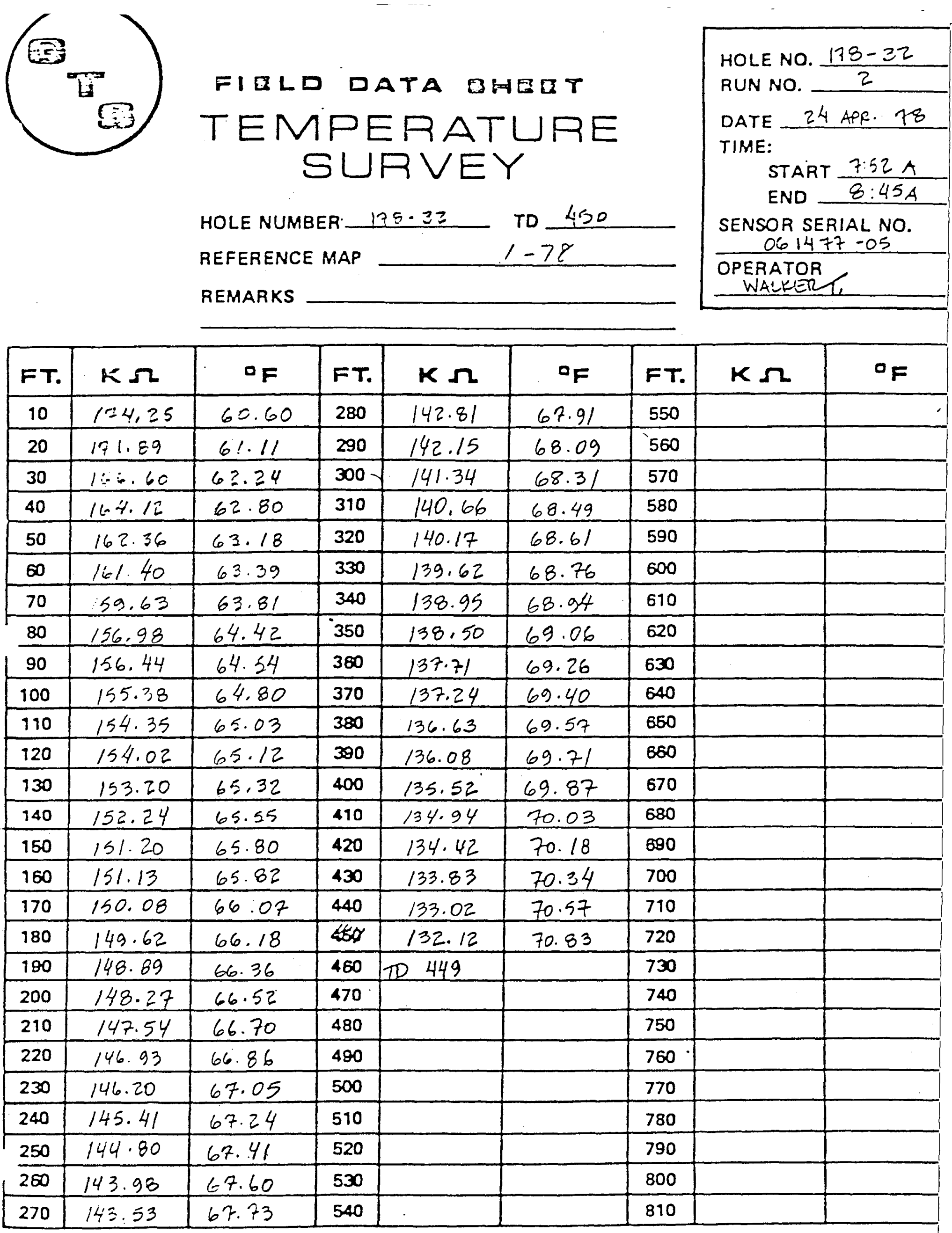


TEMHEKAIUKE (UT)

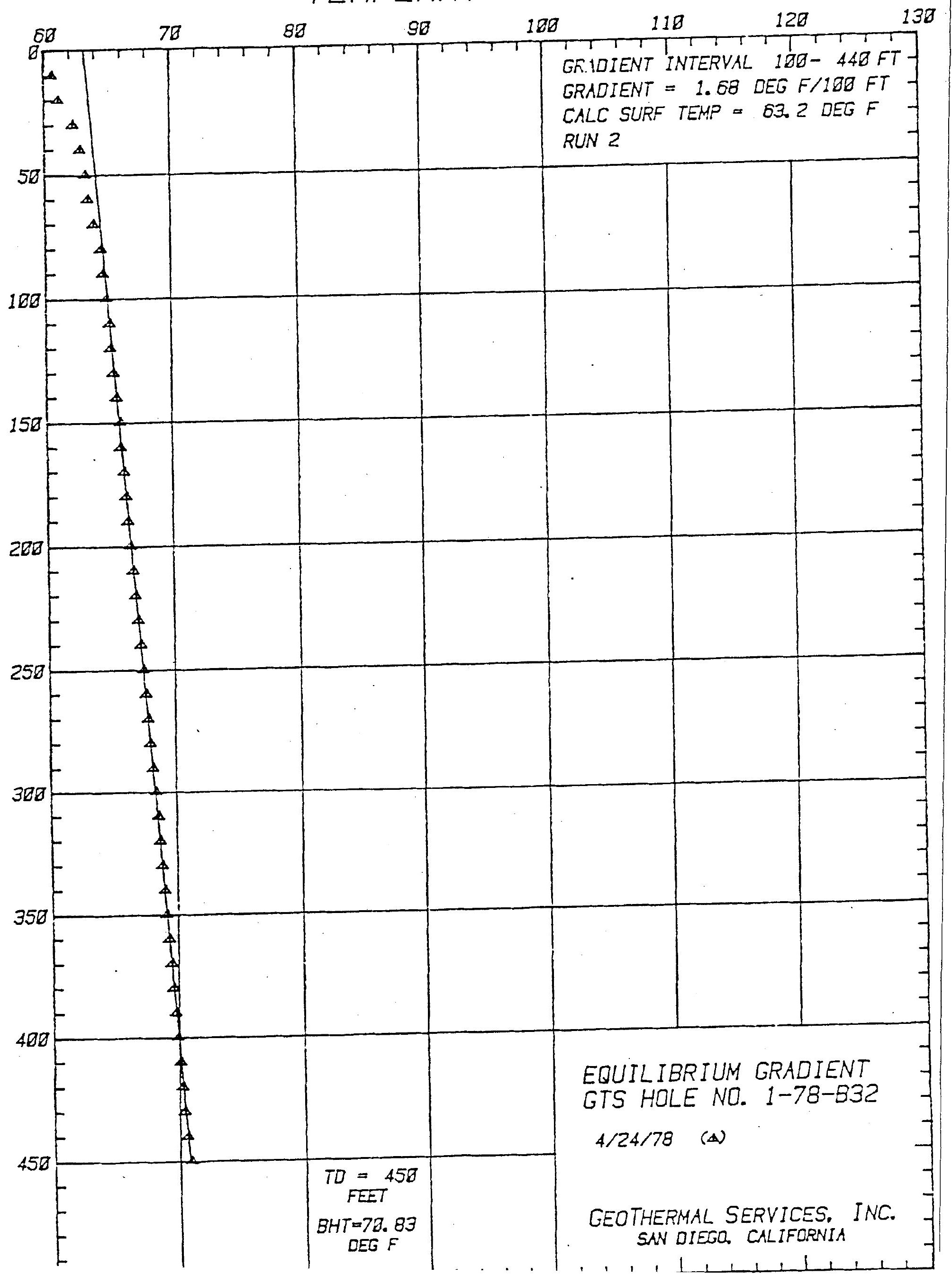


I EMIEEKA I UKE (-「'

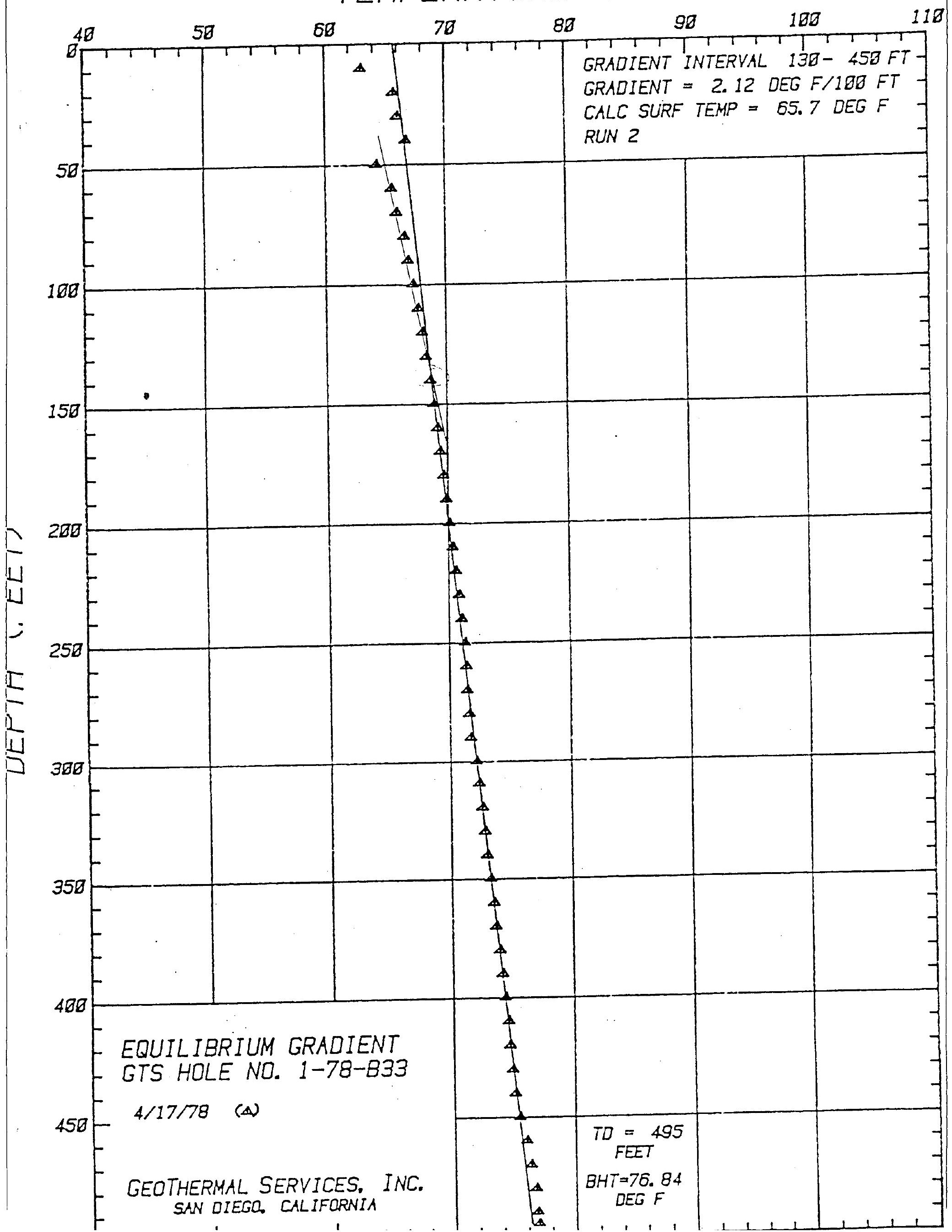




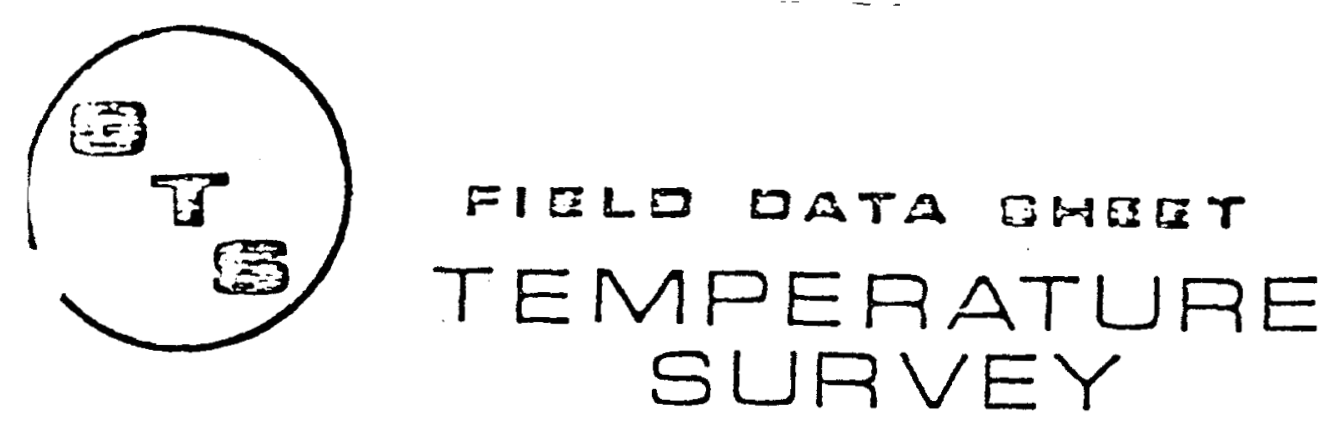

HOLE NUMBER $1-78 \quad 225$ TD $227^{\prime}$

REFERENCE MAP

$\leq-77$

REMARKS
HOLE NO. I- $=3$ C $E=$

RUN NO.

DATE IG A:16.78

TIME:

START $I I: Z 0$

END 1::05

SENSOR SERIAL NO. $4 \%$

OPERATOR

WALYERT.

\begin{tabular}{|c|c|c|c|c|c|c|c|c|}
\hline$F T$. & $k \Omega$ & ${ }^{\circ} \mathrm{F}$ & FT. & $k \Omega$ & ${ }^{\circ} \mathrm{F}$ & FT. & $K \Omega$ & ${ }^{\circ} \mathrm{F}$ \\
\hline 10 & 106.57 & 91.50 & 280 & & & 550 & & \\
\hline 20 & 116.22 & 60.23 & 290 & & & 560 & & \\
\hline 30 & 115.32 & 69.52 & 300 & & & 570 & & \\
\hline 40 & 112.20 & 69.54 & 310 & & & 580 & & \\
\hline 50 & 109.28 & 70.52 & 320 & & & 590 & & \\
\hline$\infty$ & 107.14 & 71.29 & 330 & & & 600 & & \\
\hline 70 & 105.23 & 71.96 & 340 & & & 610 & & \\
\hline 80 & 103.22 & 72.65 & 350 & & & 620 & & \\
\hline 90 & 101.184 & 72.25 & 360 & & & 630 & & \\
\hline 100 & 99.57 & 74.05 & 370 & & & 640 & & \\
\hline 110 & 97.72 & 74.76 & 380 & & & 650 & & \\
\hline 120 & 95.95 & $=5.46$ & 30 & & & 650 & & $\therefore$ \\
\hline 130 & 94.24 & 76.14 & 400 & & & 670 & & \\
\hline 140 & 92.64 & 76.80 & 410 & & & 680 & & \\
\hline 150 & 91.28 & $27 . \equiv 7$ & 420 & & & 690 & & \\
\hline 160 & 90.14 & 79.85 & 430 & & & 700 & & \\
\hline 170 & 88.477 & $=8.57$ & 440 & & & 710 & & \\
\hline 180 & 86.68 & 79.36 & 460 & & & 720 & & \\
\hline 190 & 0.5 .28 & 79.99 & 460 & & & 730 & & \\
\hline 200 & 83.10 & 00.99 & 470 & & & 740 & & \\
\hline 210 & 82.83 & 01.12 & 480 & & & 750 & & \\
\hline 220 & $8 \div 48$ & 80.81 & 490 & & & 760 & & \\
\hline 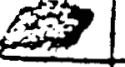 & $\therefore 4,32$ & 80.43 & 500 & & & 770 & & \\
\hline 240 & Total denth & $2 ? 7^{\prime}$ & 510 & & & 780 & & \\
\hline 250 & &.$\quad \cdots$ & 520 & & & 790 & & \\
\hline 260 & & & 530 & & & .800 & & \\
\hline 270 & & & 540 & & & 810 & & \\
\hline
\end{tabular}




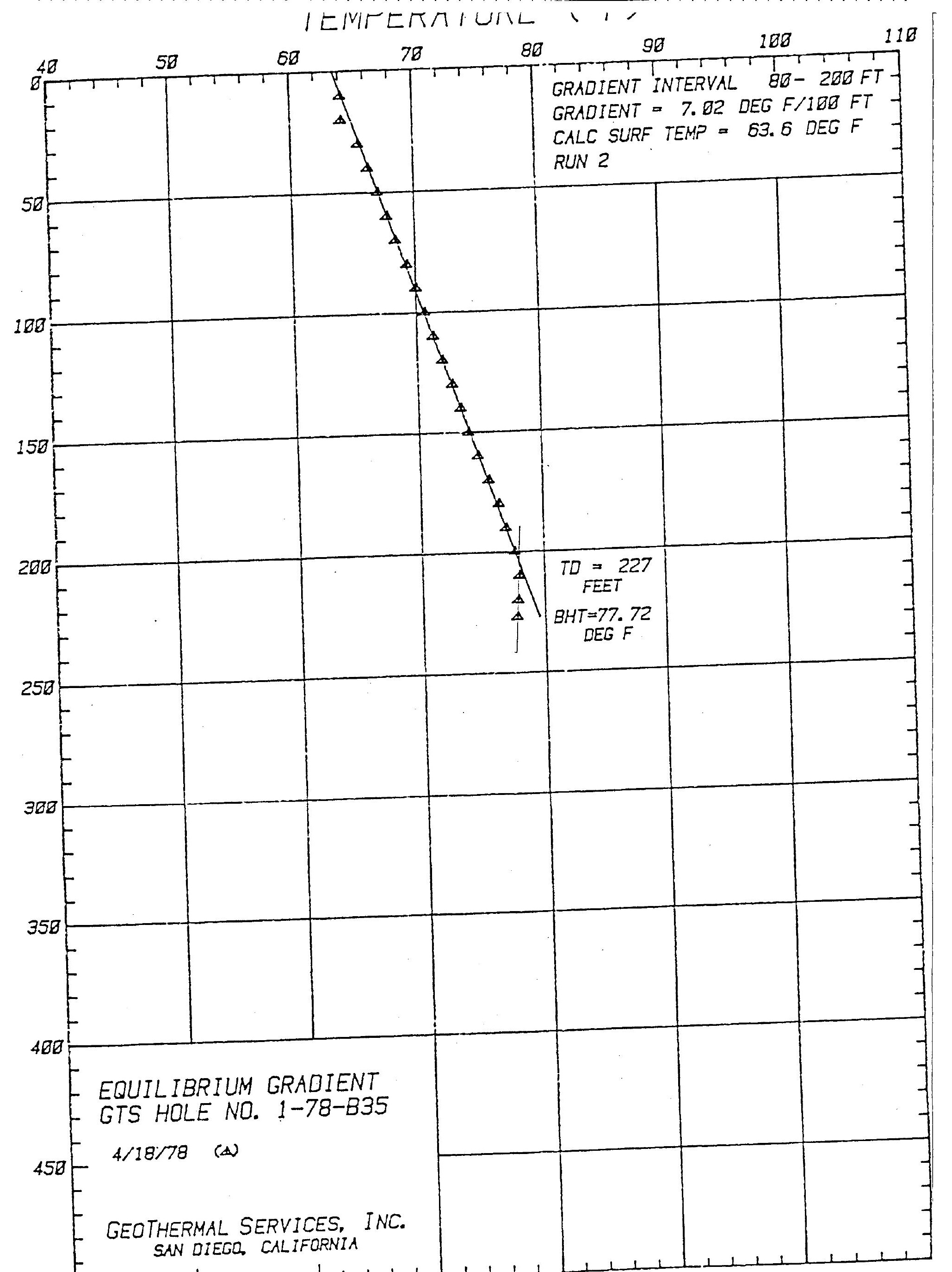




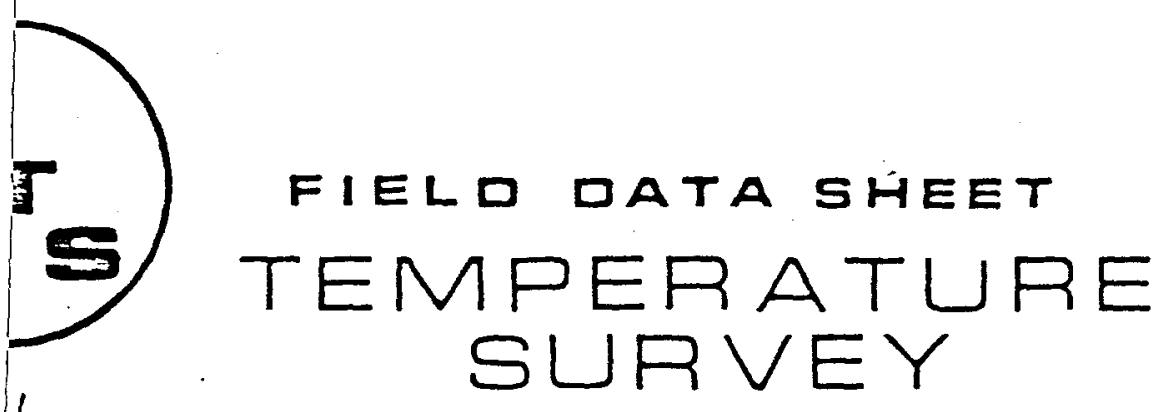

HOLE NUMBER B-40 TO ::92 REFERENCE MAP $\frac{1-78}{1-18}$

REMARKS On multimoter used in conle nit ion

\begin{tabular}{|c|c|c|c|c|c|c|c|}
\hline$K \Omega$ & ${ }^{\circ} \mathrm{F}$ & FT. & $K \Omega$ & ${ }^{\circ} \mathrm{F}$ & FT. & $K \Omega$ & ${ }^{\circ} \mathrm{F}$ \\
\hline & 69.07 & 280 & & & 550 & & 78.78 \\
\hline & & 290 & & & 560 & & \\
\hline & & 300 & & 76.70 & 570 & & \\
\hline & & 310 & & & 580 & & \\
\hline & 64.59 & 320 & & & 590 & & \\
\hline & & 330 & & & 6000 & & 79.42 \\
\hline & & 340 & & & 610 & & \\
\hline & & 350 & & 77.47 & 620 & & \\
\hline & & 360 & & & 630 & & \\
\hline & 71.32 & 370 & & & 640 & & \\
\hline & & 380 & & & 650 & & 50.1 .7 \\
\hline & & 390 & & & $660^{\circ}$ & & \\
\hline & & 400 & & $78.0 ?$ & 670 & & \\
\hline & & 410 & & & 680 & & \\
\hline & 73.28 & 420 & & & 690 & & \\
\hline & & 430 & & & 700 & & 81.70 \\
\hline & & 440 & & & 710 & & \\
\hline & & 450 & & $78 \quad 06$ & 720 & & \\
\hline & & 460 & & & 730 & & \\
\hline & 75.47 & 470 & & & 740 & & \\
\hline & & 480 & & & 750 & & se. so \\
\hline & & 490 & & & 760 & & \\
\hline & & 500 & & 78.37 & 770 & & \\
\hline & & 510 & & & 780 & & \\
\hline & 75.77 & 520 & & & 790 & & \\
\hline & & 530 & & & 800 & & $\because \div \cdots$ \\
\hline & & 540 & & & 810 & & \\
\hline
\end{tabular}




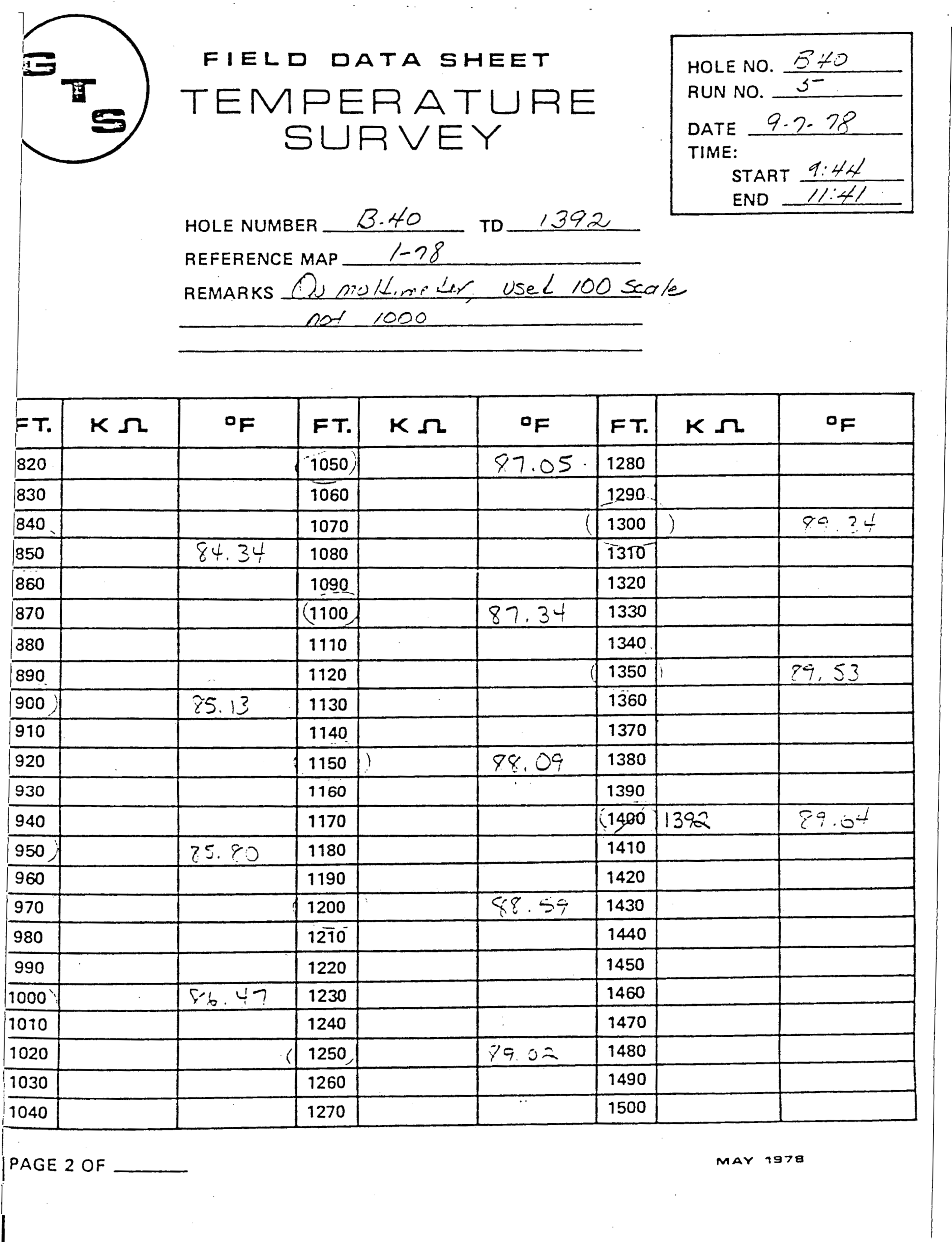




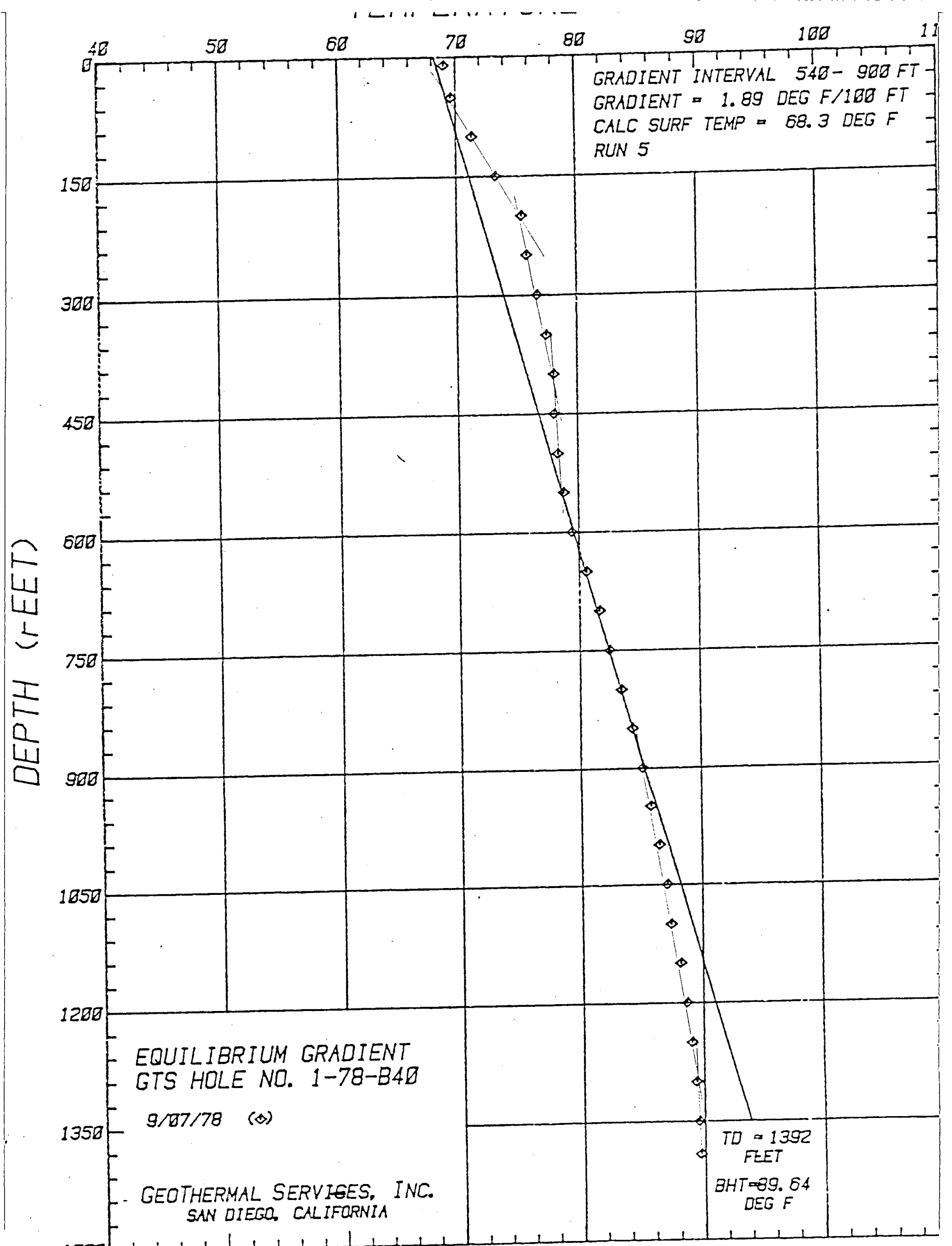


FIELD DATA BHERT $3^{2}$
HOLE NUMBER - $1-78$ U3 TD $500^{\circ}$

REFERENCE MAP

5-77
HOLE NO. $1-78113$

RUN NO. 3

DATE II JULY 78

TIME:

START $\frac{1: 30 p}{3: 00 p}$

SENSGR SERIAL NO. 496

OPERATOR

WALKER

REMARKS

\begin{tabular}{|c|c|c|c|c|c|c|c|c|}
\hline FT. & $K \Omega$ & OF & $F T$. & $K \Omega$ & ${ }^{0} \mathrm{~F}$ & FT. & $K \Omega$ & ${ }^{\circ} \mathrm{F}$ \\
\hline 10 & 107.50 & 71.15 & 280 & 96.97 & 72.05 & 550 & & \\
\hline 20 & 114.80 & 68.69 & 290 & 96.38 & 75.28 & 560 & & \\
\hline 30 & 114.60 & 68.75 & 300 & 96.45 & 75.26 & 570 & & \\
\hline 40 & 114.10 & 68.91 & 310 & 94.42 & 36.07 & 580 & & \\
\hline 50 & 112.68 & 69.05 & 320 & 95.09 & 75.80 & 590 & & \\
\hline 60 & 113.18 & 69.21 & 330 & 95.21 & 75.75 & 600 & & \\
\hline 70 & 112.50 & 69.44 & 340 & 95.28 & 76.53 & 610 & & \\
\hline 80 & 111.89 & 69.64 & 350 & 93.91 & 76.28 & 620 & & \\
\hline 90 & 111.04 & 69.95 & 360 & 93.55 & 76.42 & 630 & & \\
\hline 100 & 110.33 & 30.18 & 370 & 93.29 & $2 \operatorname{lo} .53$ & 640 & & \\
\hline 110 & 109.74 & 30.39 & 380 & 91.45 & 77.29 & 650 & & \\
\hline 120 & 109.14 & 70.59 & 390 & 91.90 & 77.11 & 680 & & \\
\hline 130 & 108.34 & 30.87 & 400 & 90.58 & 77.66 & 670 & & \\
\hline 140 & 107.66 & 71.08 & 410 & 89.66 & 79.05 & 680 & & \\
\hline 150 & 106.03 & H. 68 & 420 & 90.90 & 77.53 & 690 & & $\cdots$ \\
\hline 160 & $10^{3} .90$ & 72.43 & 430 & 89.27 & 78.22 & 700 & & $\because \because$ \\
\hline 170 & 103.23 & 72.69 & 440 & 88.70 & 3247 & 710 & & $\bar{z}$ \\
\hline 180 & 10210 & 73.09 & 460 & 883.21 & 76.68 & 720 & & \\
\hline 100 & $\ln 1.39$ & 73.35 & 460 & 87.84 & 76.84 & 730 & & \\
\hline 200 & 100.91 & 73.54 & 470 & 88.29 & 78.65 & 740 & & \\
\hline 210 & 100.27 & 73.77 & 480 & 88.50 & 78.56 & 750 & & \\
\hline 220 & 99.50 & 74.07 & 490 & 38.13 & 70.72 & 760 & & \\
\hline 230 & 99.21 & 74.18 & 500 & 88.35 & $P R, 62$ & 770 & & \\
\hline 240 & 98.48 & 74.46 & 每16 & total depth & $500^{\circ}$ & 780 & & \\
\hline 250 & 97.94 & 74.67 & 520 & & & 790 & & \\
\hline 260 & 97.67 & 74.78 & 530 & & & 800 & & \\
\hline 270 & 97.27 & 74.93 & 540 & & & 810 & & \\
\hline
\end{tabular}




\section{TEMPERATURE (OF)}

\begin{tabular}{|c|c|c|c|c|c|c|}
\hline & & & & \\
\hline
\end{tabular}




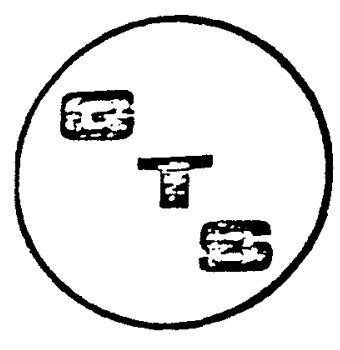

\section{FIELD DATA OHEET TEMPERATURE SURVEY} HOLE NUMBER. $1-78$ U4 TD $376^{\prime}$ REFERENCE MAP $\quad 5-77$ REMARKS
HOLE NO. 1.79 U4 RUN NO. 3

DATE 22 JULY 78

TIME:

START 6:10P END 7:05P SENSOR SERIAL NO. 4 H6 OPERATOR

WALKERT.

\begin{tabular}{|c|c|c|c|c|c|c|c|c|}
\hline FT. & $K \Omega$ & ${ }^{\circ} F$ & FT. & $K \Omega$ & ${ }^{\circ} \mathrm{F}$. & FT. & $K \Omega$ & ${ }^{\circ F}$ \\
\hline 10 & 98.01 & 74.65 & 280 & 97.07 & $7 F_{2} .01$ & 550 & & \\
\hline 20 & $\operatorname{lin} .50$ & 70.11 & 290 & 96.51 & 75.2 .5 & 560 & & \\
\hline 30 & 111.7 & 69.71 & 300 & 96.08 & 75.40 & 570 & & \\
\hline 40 & 111.38 & 69.81 & 310 & 94.95 & 75.86 & 580 & & \\
\hline 50 & 111.49 & 69.78 & 320 & 94.62 & 75.99 & 590 & & \\
\hline 60 & 111.22 & 69.88 & 330 & 93.16 & 76.58 & 600 & & \\
\hline 70 & 110.86 & 69.98 & 340 & 93.36 & 76.50 & 610 & & \\
\hline 80 & 110.15 & 70.22 & 350 & 92.93 & 76.68 & 620 & & \\
\hline 90 & 109.92 & 70.39 & 360 & 91.93 & 77.09 & 630 & & \\
\hline 100 & 109.27 & 70.52 & 370 & 90.81 & 77.56 & 640 & & \\
\hline 110 & 108.61 & 70.77 & 4 & $\because 90.44$, & $=77.72^{\prime}$ & 650 & & \\
\hline 120 & 108.21 & 70.90 & 390 & totaldect & $376^{\prime}$ & 680 & & \\
\hline 130 & 107.54 & $71 \cdot 15$ & 400 & & & 670 & & \\
\hline 140 & 106,76 & 71.39 & 410 & & & 680 & & \\
\hline 150 & 104.73 & 72.14 & 420 & & & 690 & & \\
\hline 160 & 104.14 & 72.36 & 430 & 4 & & 700 & & \\
\hline 170 & 103.51 & 72.58 & 440 & & & 710 & & \\
\hline 180 & 102.39 & 72.84 & 450 & & & 720 & & \\
\hline 180 & 102.14 & 73.09 & 480 & & & 730 & & \\
\hline 200 & 102.03 & 73.13 & 470 & & & 740 & & \\
\hline 210 & 100.94 & 73.58 & 480 & & & 750 & & \\
\hline 220 & 100.82 & 73.58 & 490 & & & 760 & & \\
\hline 230 & 100.14 & $73.8,4$ & 500 & & & 770 & & \\
\hline 240 & 99.68 & 24.00 & 510 & & & 780 & & \\
\hline 250 & 98.34 & $=44.44$ & 520 & & & 790 & & \\
\hline 260 & 98.22 & 24.56 & 530 & & & 800 & & \\
\hline 270 & 97.81 & 74.72 & 540 & & & 810 & & \\
\hline
\end{tabular}




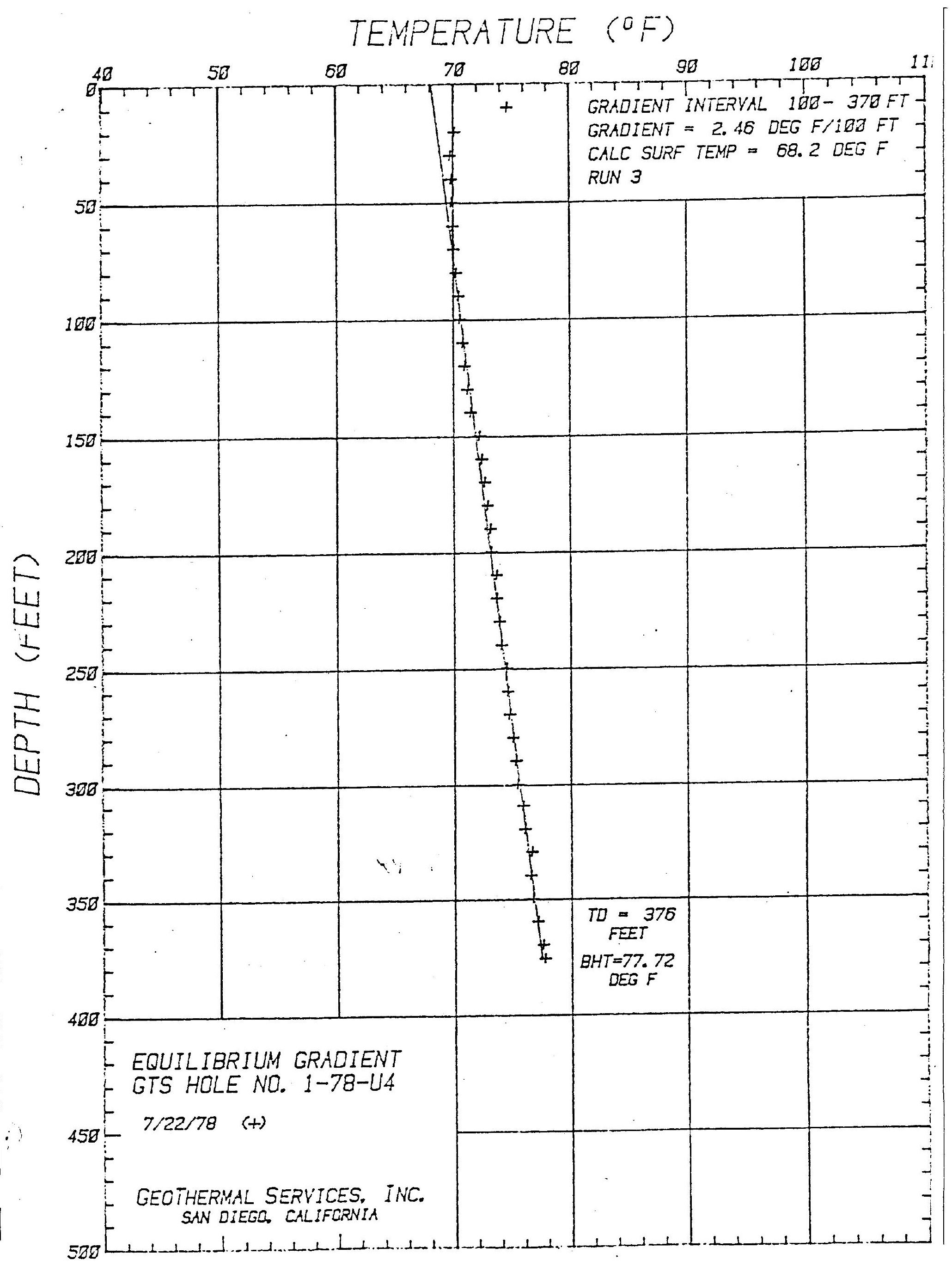


GULF MINERAL RESOURCES COMPANY

\section{T.G. HOLE STROZZI \# IB}

T. 3 S., R. 2 W., Sec. 1

7/9/79 9:52 PM

Logged by GeothermEx, Inc.

\begin{tabular}{|c|c|c|c|c|c|c|c|c|c|}
\hline $\begin{array}{l}\text { Depth, } \\
\text { In feet }\end{array}$ & & $\begin{array}{l}\text { Depth, } \\
\text { in meters }\end{array}$ & ${ }^{o} \mathrm{~F}$ & ${ }^{\circ} \mathrm{C}$ & & $\begin{array}{l}\text { Depth, } \\
\text { in feet }\end{array}$ & $\begin{array}{c}\text { Depth, } \\
\text { In meters } \\
\end{array}$ & $o_{F}$ & ${ }^{\circ} \mathrm{C}$ \\
\hline 10 & & 3.0 & ---- & - - & & 260 & 79.2 & 65.48 & 18.60 \\
\hline 20 & & 6.1 & 61.68 & 16.49 & & 270 & 82.3 & 65.70 & 18.72 \\
\hline 30 & & 9.1 & 62.31 & 16.84 & & 280 & 85.3 & 65.98 & 18.88 \\
\hline 40 & 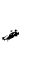 & 12.2 & 62.74 & 17.08 & & 290 & 88.4 & 66.25 & 19.03 \\
\hline 50 & & 15.2 & 62.83 & 17.13 & & 300 & 91.4 & 66.52 & 19.18 \\
\hline 60 & & 18.3 & 62.83 & 17.13 & & 310 & 94.5 & 66.85 & 19.36 \\
\hline 70 & & 21.3 & 62.91 & 17.17 & & 320 & 97.5 & 67.12 & 19.51 \\
\hline 80 & & 24.4 & 62.98 & 17.21 & & 330 & 100.6 & 67.44 & 19.69 \\
\hline 90 & & 27.4 & 63.05 & 17.25 & & 340 & 103.6 & 67.75 & 19.86 \\
\hline 100 & & 30.5 & 63.18 & 17.32 & & 350 & 106.7 & 68.02 & 20.01 \\
\hline 110 & & 33.5 & 63.28 & 17.38 & & 360 & 109.7 & 68.32 & 20.18 \\
\hline 120 & & 36.6 & 63.41 & 17.45 & & 370 & 112.8 & 68.65 & 20.36 \\
\hline 130 & & 39.6 & 63.52 & 17.51 & & 380 & 115.8 & 68.94 & 20.52 \\
\hline 140 & & 42.7 & 63.63 & 17.57 & & 390 & 118.9 & 69.22 & 20.68 \\
\hline 150 & & 45.7 & 63.75 & 17.64 & & 400 & 121.9 & 69.53 & 20.85 \\
\hline 160 & & 48.8 & 63.82 & 17.68 & & 410 & 125.0 & 69.85 & 21.03 \\
\hline 170 & & 51.8 & 63.97 & 17.76 & & 420 & 128.0 & 70.16 & 21.20 \\
\hline 180 & & 54.9 & 64.06 & 17.81 & & 430 & 131.1 & 70.50 & 21.39 \\
\hline 190 & & 57.9 & 64.20 & 17.89 & & 440 & 134.1 & 70.86 & 21.59 \\
\hline 200 & & 61.0 & 64.31 & 17.95 & & 450 & 137.2 & 71.19 & 21.77 \\
\hline 210 & & 64.0 & 64.47 & 18.04 & & 460 & 140.2 & 71.51 & 21.95 \\
\hline 220 & & 67.1 & 64.62 & 18.12 & & 470 & 143.3 & 71.89 & 22.16 \\
\hline 230 & & 70.1 & 64.78 & 18.21 & & 480 & 146.3 & 72.18 & 22.32 \\
\hline 240 & & 73.2 & 64.98 & 18.32 & & 490 & 149.4 & 72.59 & 22.55 \\
\hline \multirow[t]{2}{*}{250} & & 76.2 & 65.26 & 18.48 & & 500 & 152.4 & 72.88 & 22.71 \\
\hline & & & & & & 504 & 153.6 & 72.97 & 22.76 \\
\hline
\end{tabular}

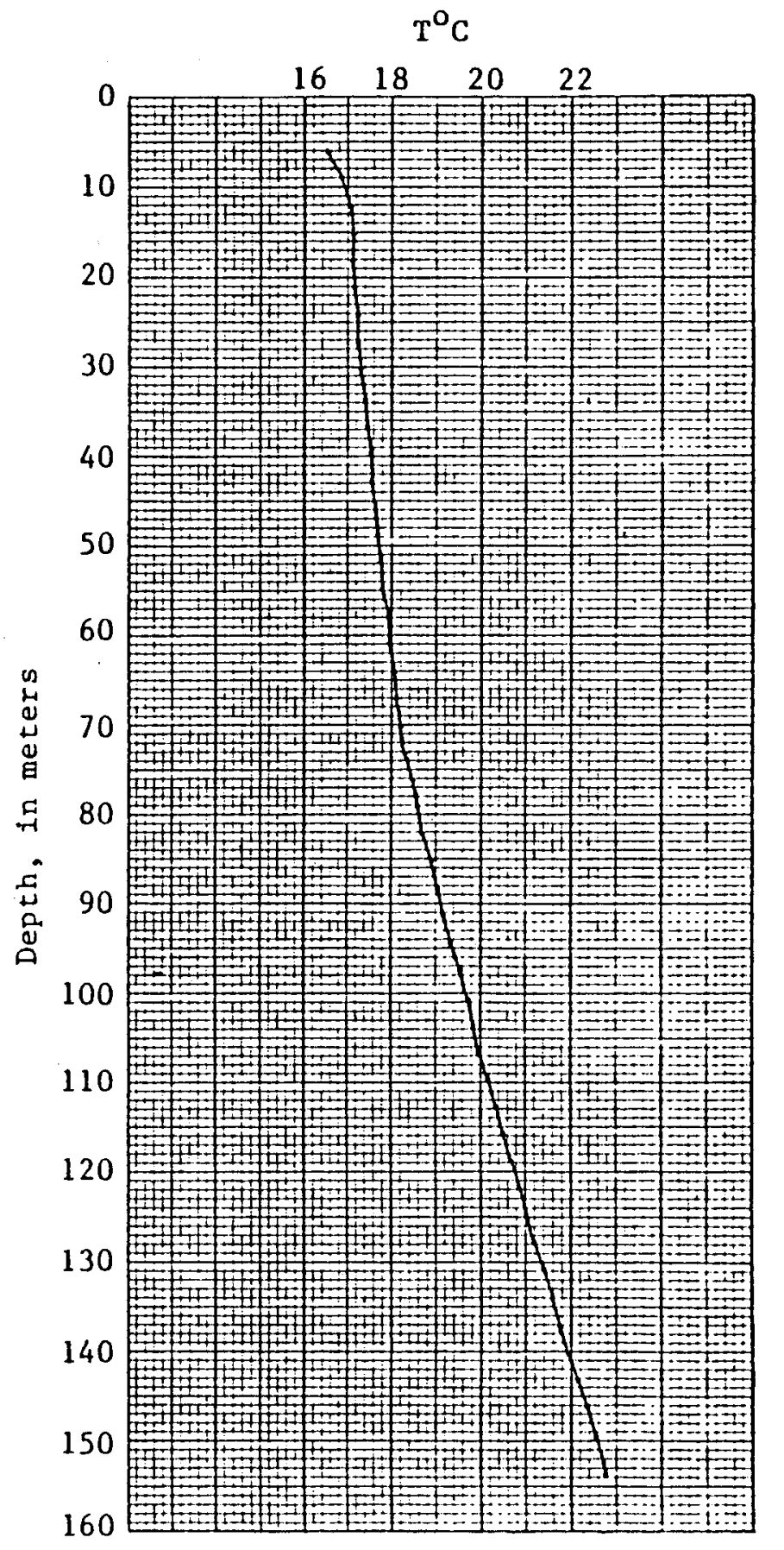


GULF MINERAL RESOURCES COMPANY

\section{SOCORRO PROSPECT}

T.G. HOLE STROZZI \#2B

T. 3 S., R. 2 W., Sec. 2

7/9/79 12:31 PM

Logged by GeothermEx, Inc.

Depth, Depth, in feet in meters

10
20
30
40
50
60
70
80
90
100
110
120
130
140
150
160
170
180
190
200
210
220
230
240

3.0

6.1

9.1

12.2

15.2

18.3

21.3

24.4

27.4

30.5

33.5

36.6

39.6

42.7

45.7

48.8

51.8

54.9

57.9

61.0

64.0

67.1

70.1

73.2

\begin{tabular}{|c|c|c|c|}
\hline $\begin{array}{l}\text { Depth, } \\
\text { in feet }\end{array}$ & $\begin{array}{c}\text { Depth, } \\
\text { in meters }\end{array}$ & ${ }^{\circ} \mathrm{F}$ & ${ }^{\circ} \mathrm{C}$ \\
\hline 250 & 76.2 & 67.35 & 19.64 \\
\hline 260 & 79.2 & 67.66 & 19.81 \\
\hline 270 & 82.3 & 67.86 & 19.92 \\
\hline 280 & 85.3 & 68.13 & 20.07 \\
\hline 290 & 88.4 & 68.43 & 20.24 \\
\hline 300 & 91.4 & 68.68 & 20.38 \\
\hline 310 & 94.5 & 68.92 & 20.51 \\
\hline 320 & 97.5 & 69.24 & 20.69 \\
\hline 330 & 100.6 & 69.51 & 20.84 \\
\hline 340 & 103.6 & 69.82 & 21.01 \\
\hline 350 & 106.7 & 70.09 & 21.16 \\
\hline 360 & 109.7 & 70.41 & 21.34 \\
\hline 370 & 112.8 & 70.77 & 21.54 \\
\hline 380 & 115.8 & 71.06 & 21.70 \\
\hline 390 & 118.9 & 71.40 & 21.89 \\
\hline 400 & 121.9 & 71.73 & 22.07 \\
\hline 410 & 125.0 & 72.01 & 22.23 \\
\hline 420 & 128.0 & 72.36 & 22.42 \\
\hline 430 & 131.1 & 72.64 & 22.58 \\
\hline 440 & 134.1 & 73.00 & 22.78 \\
\hline 450 & 137.2 & 73.27 & 22.93 \\
\hline 460 & 140.2 & 73.56 & 23.09 \\
\hline 470 & 143.3 & 73.81 & 23.23 \\
\hline 480 & 146.3 & 73.92 & 23.29 \\
\hline
\end{tabular}

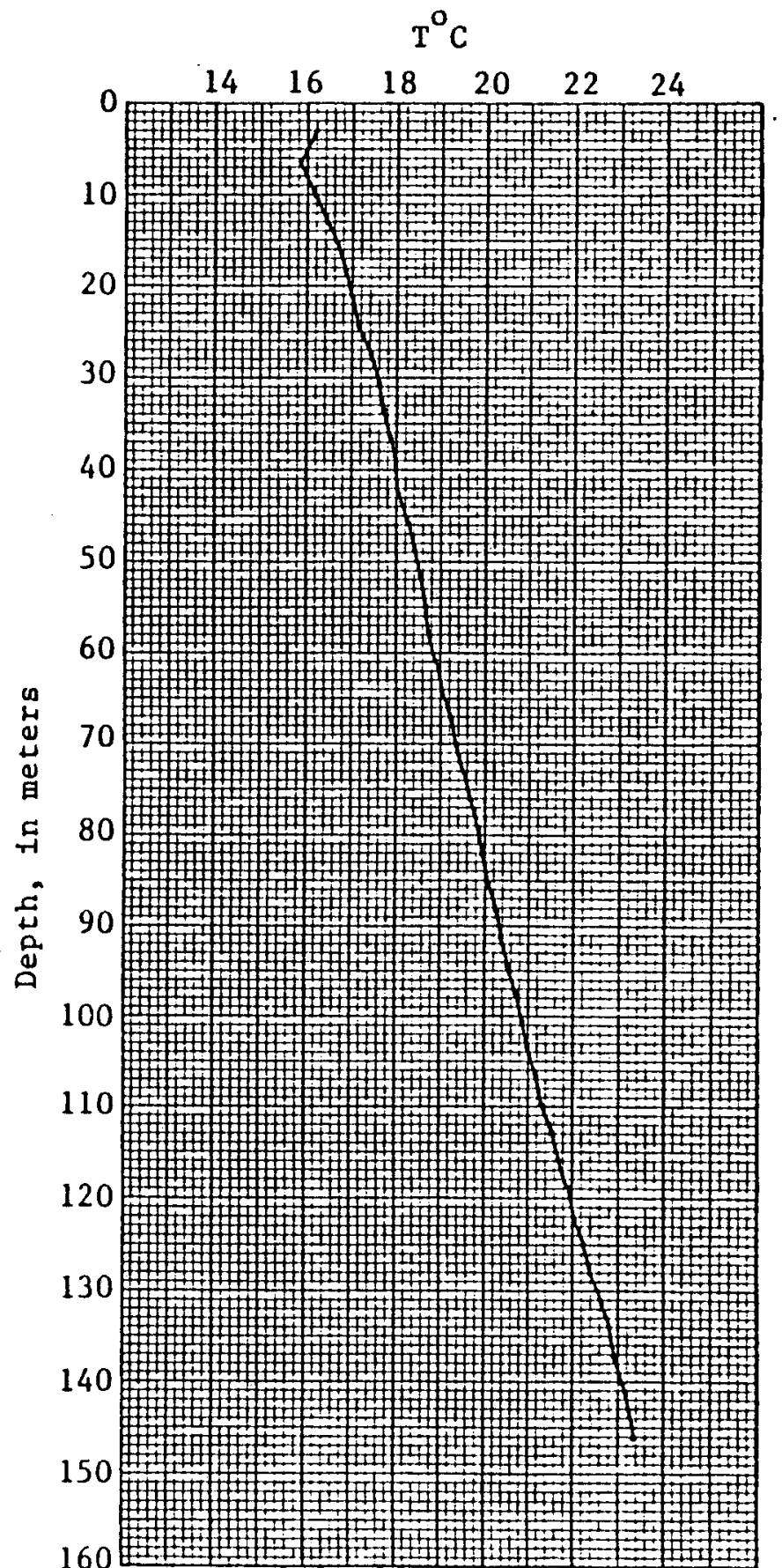


GULF MINERAL RESOURCES COMPANY

\section{SOCORRO PROSPECT}

\section{T.G. HOLE STROZZI \#3}

T. 3 S., R. 2 W., Sec. 2

7/9/79 2:01 PM

Logged by GeothermEx, Inc.

\begin{tabular}{|c|c|c|c|c|c|c|c|}
\hline $\begin{array}{l}\text { Depth, } \\
\text { in feet }\end{array}$ & $\begin{array}{c}\text { Depth, } \\
\text { in meters }\end{array}$ & ${ }^{o_{F}}$ & ${ }^{\circ} \mathrm{C}$ & $\begin{array}{l}\text { Depth, } \\
\text { in feet }\end{array}$ & $\begin{array}{c}\text { Depth, } \\
\text { in meters } \\
\end{array}$ & ${ }^{\circ} \mathrm{E}$ & ${ }^{\circ} \mathrm{C}$ \\
\hline 10 & 3.0 & 62.69 & 17.05 & 260 & 79.2 & 64.20 & 17.89 \\
\hline 20 & 6.1 & 59.79 & 15.44 & 270 & 82.3 & 64.35 & 17.97 \\
\hline 30 & 9.1 & 60.49 & 15.83 & 280 & 85.3 & 64.51 & 18.06 \\
\hline 40 & 12.2 & 60.93 & 16.07 & 290 & 88.4 & 64.67 & 18.15 \\
\hline 50 & 15.2 & 61.11 & 16.17 & 300 & 91.4 & 64.85 & 18.25 \\
\hline 60 & 18.3 & 61.34 & 16.30 & 310 & 94.5 & 65.01 & 18.34 \\
\hline 70 & 21.3 & 61.50 & 16.39 & 320 & 97.5 & 65.14 & 18.41 \\
\hline 80 & 24.4 & 61.68 & 16.49 & 330 & 100.6 & 65.30 & 18.50 \\
\hline 90 & 27.4 & 61.83 & 16.57 & 340 & 103.6 & 65.48 & 18.60 \\
\hline 100 & 30.5 & 62.01 & 16.67 & 350 & 106.7 & 65.64 & 18.69 \\
\hline 110 & 33.5 & 62.13 & 16.74 & 360 & 109.7 & 65.80 & 18.78 \\
\hline 120 & 36.6 & 62.24 & 16.80 & 370 & 112.8 & 65.98 & 18.88 \\
\hline 130 & 39.6 & 62.37 & 16.87 & 380 & 115.8 & 66.16 & 18.98 \\
\hline 140 & 42.7 & 62.58 & 16.99 & 390 & 118.9 & 66.34 & 19.08 \\
\hline 150 & 45.7 & 62.71 & 17.06 & 400 & 121.9 & 66.51 & 19.17 \\
\hline 160 & 48.8 & 62.83 & 17.13 & 410 & 125.0 & 66.70 & 19.28 \\
\hline 170 & 51.8 & 62.94 & 17.19 & 420 & 128.0 & 66.85 & 19.36 \\
\hline 180 & 54.9 & 63.09 & 17.27 & 430 & 131.1 & 67.06 & 19.48 \\
\hline 190 & 57.9 & 63.21 & 17.34 & 440 & 134.1 & 67.23 & 19.57 \\
\hline 200 & 61.0 & 63.34 & 17.41 & 450 & 137.2 & 67.39 & 19.66 \\
\hline 210 & 64.0 & 63.46 & 17.48 & 460 & 140.2 & 67.59 & 19.77 \\
\hline 220 & 67.1 & 63.63 & 17.57 & 470 & 143.3 & 67.78 & 19.88 \\
\hline 230 & 70.1 & 63.75 & 17.64 & 480 & 146.3 & 67.95 & 19.97 \\
\hline 240 & 73.2 & 63.91 & 17.73 & 490 & 149.4 & 68.11 & 20.06 \\
\hline 250 & 76.2 & 64.04 & 17.80 & 493 & 150.3 & 68.16 & 20.09 \\
\hline
\end{tabular}

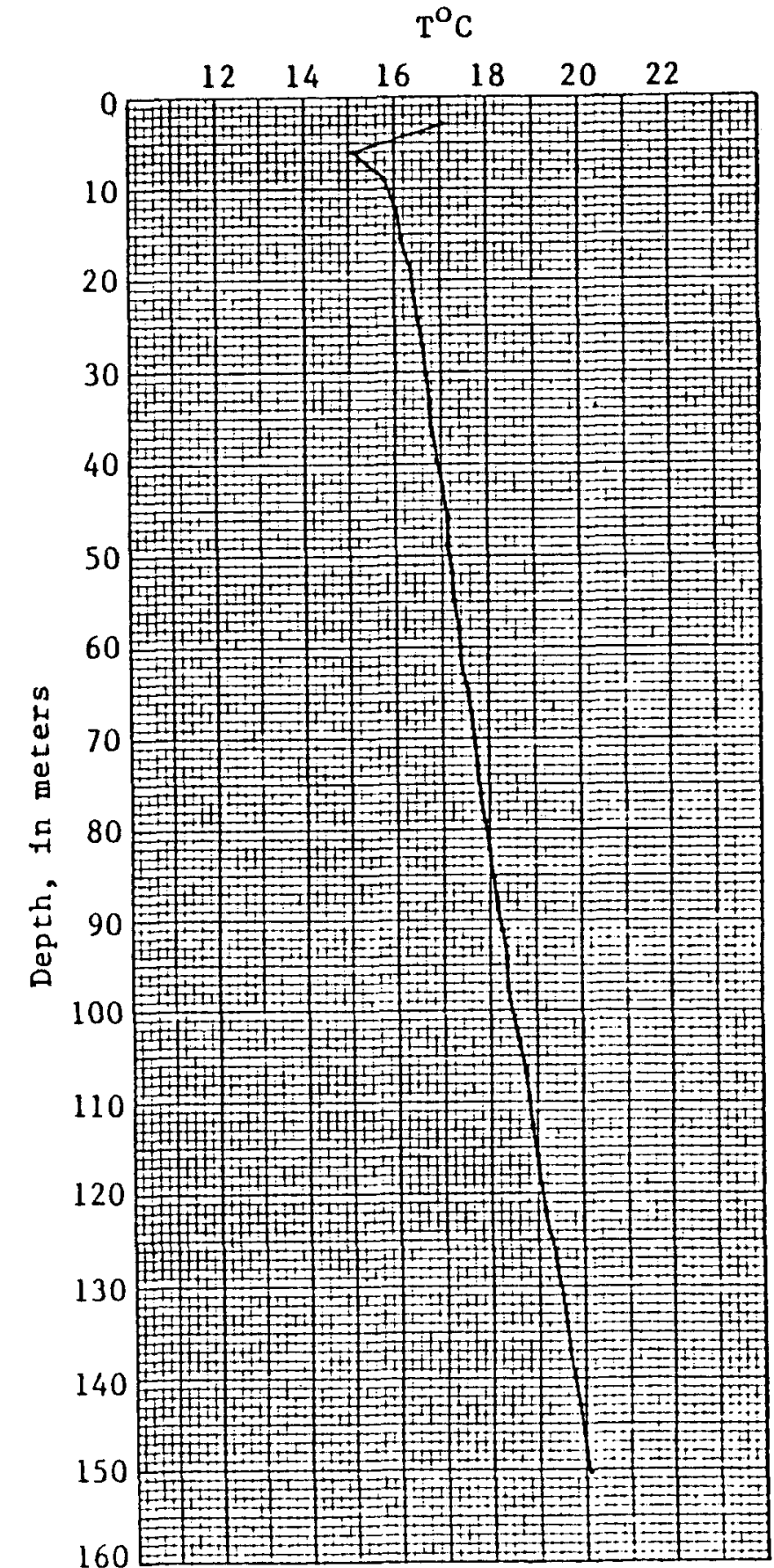


GULF MINERAL RESOURCES COMPANY

\section{SOCORRO PROSPECT}

T.G. HOLE STROZZI \#4

T. 2 S., R. 2 W., Sec. 34

7/9/79 3:44 PM

Logged by GeothermEx, Inc.

\begin{tabular}{|c|c|c|c|c|c|c|c|}
\hline $\begin{array}{l}\text { Depth, } \\
\text { in feet }\end{array}$ & $\begin{array}{c}\text { Depth, } \\
\text { in meters } \\
\end{array}$ & $o_{F}$ & ${ }^{\circ} \mathrm{C}$ & $\begin{array}{l}\text { Depth, } \\
\text { in feet }\end{array}$ & $\begin{array}{c}\text { Depth, } \\
\text { in meters }\end{array}$ & ${ }^{o} \mathrm{~F}$ & ${ }^{\circ} \mathrm{C}$ \\
\hline 10 & 3.0 & 63.05 & 17.25 & 260 & 79.2 & 63.95 & 17.75 \\
\hline 20 & 6.1 & 59.77 & 15.43 & 270 & 82.3 & 64.06 & 17.81 \\
\hline 30 & 9.1 & 60.39 & 15.77 & 280 & 85.3 & 64.18 & 17.88 \\
\hline 40 & 12.2 & 60.96 & 16.09 & 290 & 88.4 & 64.35 & 17.97 \\
\hline 50 & 15.2 & 61.29 & 16.27 & 300 & 91.4 & 64.49 & 18.05 \\
\hline 60 & 18.3 & 61.34 & 16.30 & 310 & 94.5 & 64.69 & 18.16 \\
\hline 70 & 21.3 & 61.45 & 16.36 & 320 & 97.5 & 64.92 & 18.29 \\
\hline 80 & 24.4 & 61.54 & 16.41 & 330 & 100.6 & 65.08 & 18.38 \\
\hline 90 & 27.4 & 61.66 & 16.48 & 340 & 103.6 & 65.23 & 18.46 \\
\hline 100 & 30.5 & 61.75 & 16.53 & 350 & 106.7 & 65.46 & 18.59 \\
\hline 110 & 33.5 & 61.90 & 16.61 & 360 & 109.7 & 65.59 & 18.66 \\
\hline 120 & 36.6 & 62.04 & 16.69 & 370 & 112.8 & 65.77 & 18.76 \\
\hline 130 & 39.6 & 62.15 & 16.75 & 380 & 115.8 & 66.04 & 18.91 \\
\hline 140 & 42.7 & 62.28 & 16.82 & 390 & 118.9 & 66.22 & 19.01 \\
\hline 150 & 45.7 & 62.42 & 16.90 & 400 & 121.9 & 66.36 & 19.09 \\
\hline 160 & 48.8 & 62.58 & 16.99 & 410 & 125.0 & 66.58 & 19.21 \\
\hline 170 & 51.8 & 62.71 & 17.06 & 420 & 128.0 & 66.76 & 19.31 \\
\hline 180 & 54.9 & 62.85 & 17.14 & 430 & 131.1 & 66.92 & 19.40 \\
\hline 190 & 57.9 & 63.00 & 17.22 & 440 & 134.1 & 67.12 & 19.51 \\
\hline 200 & 61.0 & 63.10 & 17.28 & 450 & 137.2 & 67.32 & 19.62 \\
\hline 210 & 64.0 & 63.25 & 17.36 & 460 & 140.2 & 67.48 & 19.71 \\
\hline 220 & 67.1 & 63.37 & 17.43 & 470 & 143.3 & 67.62 & 19.79 \\
\hline 230 & 70.1 & 63.50 & 17.50 & 480 & 146.3 & 67.77 & 19.87 \\
\hline 240 & 73.2 & 63.63 & 17.57 & 490 & 149.4 & 68.09 & 20.05 \\
\hline 250 & 76.2 & 63.77 & 17.65 & 499 & 152.1 & 68.29 & 20.16 \\
\hline
\end{tabular}

$\mathrm{T}^{\mathrm{o}} \mathrm{C}$

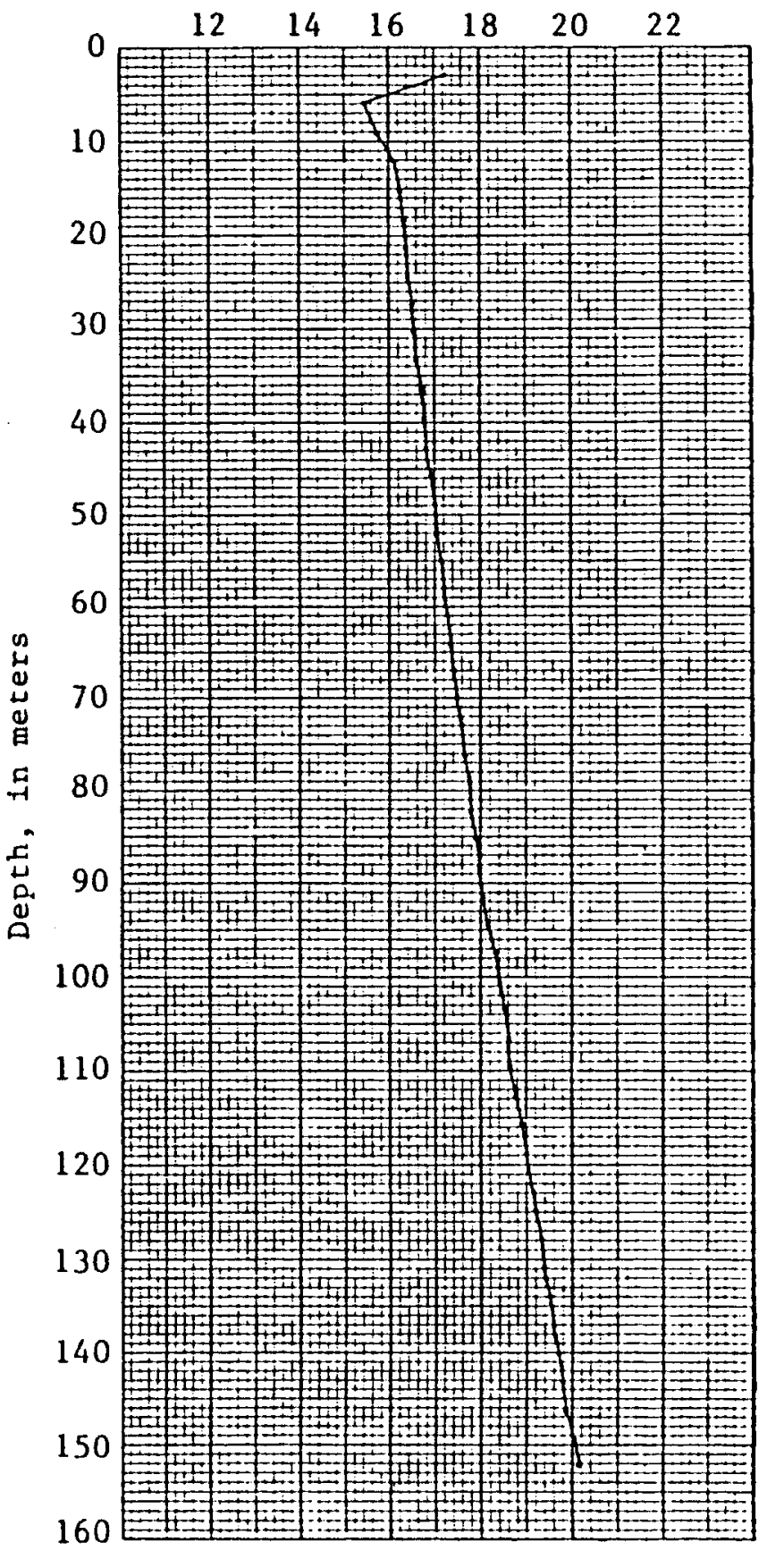


GULF MINERAL RESOURCES COMPANY

\section{SOCORRO PROSPECT}

T.G. HOLE STROZZI \#5

T. 3 S., R. 2 W., Sec. 3

7/10/79 12:16 PM

Logged by GeothermEx, Inc.

\begin{tabular}{|c|c|c|c|c|c|c|c|}
\hline $\begin{array}{l}\text { Depth, } \\
\text { in feet }\end{array}$ & $\begin{array}{c}\text { Depth, } \\
\text { In meters }\end{array}$ & $o_{F}$ & ${ }^{\circ} \mathrm{C}$ & $\begin{array}{l}\text { Depth, } \\
\text { in feet }\end{array}$ & $\begin{array}{l}\text { Depth, } \\
\text { in meters } \\
\end{array}$ & ${ }^{o} \mathrm{~F}$ & ${ }^{\circ} \mathrm{C}$ \\
\hline 10 & 3.0 & 60.33 & 15.74 & 270 & 82.3 & 62.47 & 16.93 \\
\hline 20 & 6.1 & 59.81 & 15.45 & 280 & 85.3 & 62.56 & 16.98 \\
\hline 30 & 9.1 & 60.53 & 15.85 & 290 & 88.4 & 62.65 & 17.03 \\
\hline 40 & 12.2 & 60.85 & 16.03 & 300 & 91.4 & 62.76 & 17.09 \\
\hline 50 & 15.2 & 61.03 & 16.13 & 310 & 94.5 & 62.83 & 17.13 \\
\hline 60 & 18.3 & 61.12 & 16.18 & 320 & 97.5 & 62.92 & 17.18 \\
\hline 70 & 21.3 & 61.21 & 16.23 & 330 & 100.6 & 63.01 & 17.23 \\
\hline 80 & 24.4 & 61.32 & 16.29 & 340 & 103.6 & 63.09 & 17.27 \\
\hline 90 & 27.4 & 61.36 & 16.31 & 350 & 106.7 & 63.18 & 17.32 \\
\hline 100 & 30.5 & 61.36 & 16.31 & 360 & 109.7 & 63.27 & 17.37 \\
\hline 110 & 33.5 & 61.45 & 16.36 & 370 & 112.8 & 63.37 & 17.43 \\
\hline 120 & 36.6 & 61.61 & 16.45 & 380 & 115.8 & 63.45 & 17.47 \\
\hline 130 & 39.6 & 61.79 & 16.55 & 390 & 118.9 & 63.55 & 17.53 \\
\hline 1.40 & 42.7 & 61.79 & 16.55 & 400 & 121.9 & 63.66 & 17.59 \\
\hline 150 & 45.7 & 61.86 & 16.59 & 410 & 125.0 & 63.75 & 17.64 \\
\hline 160 & 48.8 & 61.74 & 16.52 & 420 & 128.0 & 63.84 & 17.69 \\
\hline 170 & 51.8 & 61.68 & 16.49 & 430 & 131.1 & 63.93 & 17.74 \\
\hline 180 & 54.9 & 61.72 & 16.51 & 440 & 134.1 & 64.04 & 17.80 \\
\hline 190 & 57.9 & 61.77 & 16.54 & 450 & 137.2 & 64.15 & 17.86 \\
\hline 200 & 61.0 & 61.86 & 16.59 & 460 & 140.2 & 64.24 & 17.91 \\
\hline 210 & 64.0 & 61.93 & 16.63 & 470 & 143.3 & 64.35 & 17.97 \\
\hline 220 & 67.1 & 62.01 & 16.67 & 480 & 146.3 & 64.45 & 18.03 \\
\hline 230 & 70.1 & 62.08 & 16.71 & 490 & 149.4 & 64.56 & 18.09 \\
\hline 240 & 73.2 & 62.17 & 16.76 & 500 & 152.4 & 64.67 & 18.15 \\
\hline 250 & 76.2 & 62.28 & 16.82 & 504 & 153.6 & 64.69 & 18.16 \\
\hline 260 & 79.2 & 62.37 & 16.87 & & & & \\
\hline
\end{tabular}

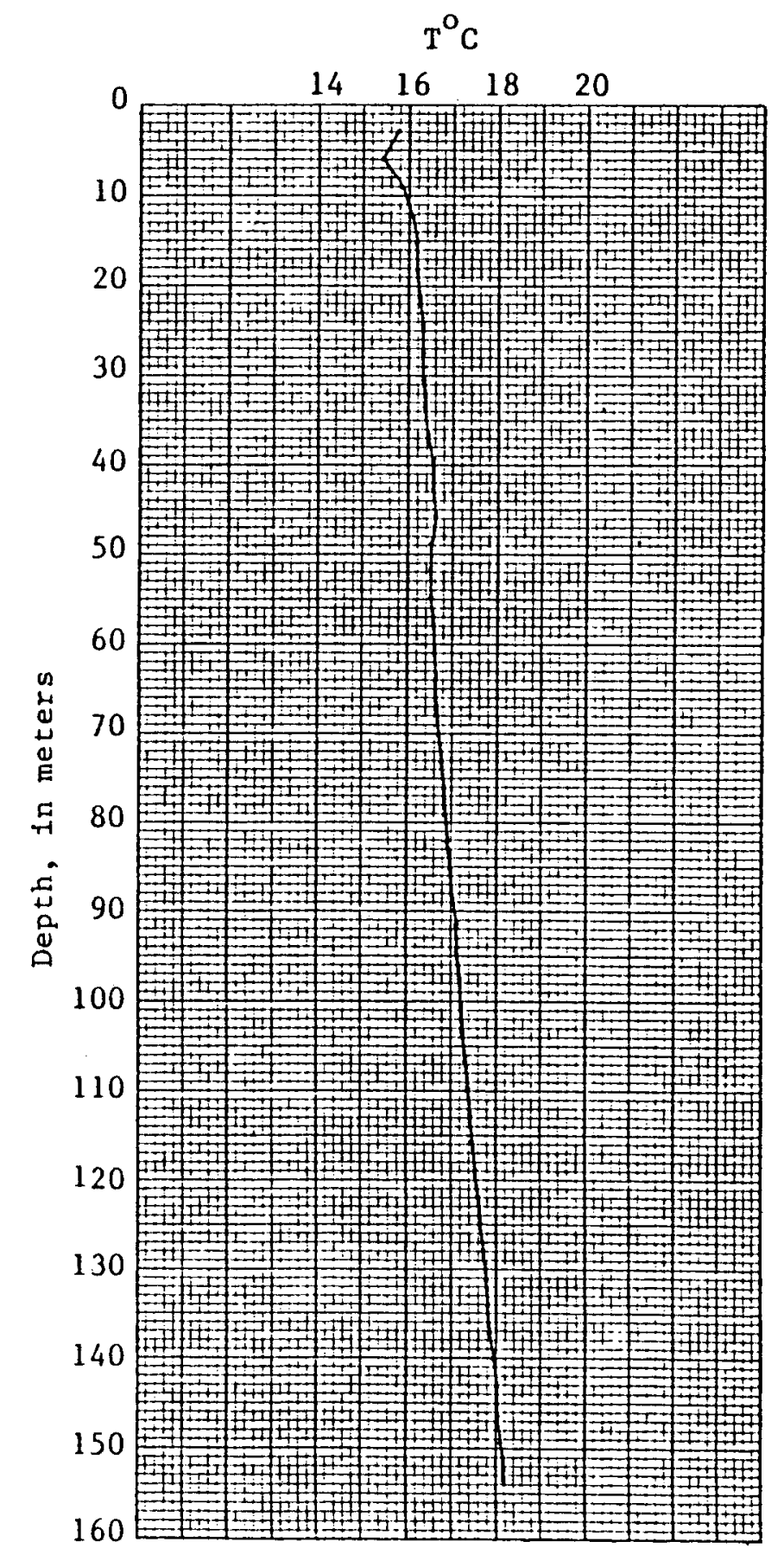


GULF MINERAL RESOURCES COMPANY

SOCORRO PROSPECT

\section{T.G. HOLE STROZZI \#7}

T. 3 S., R. 2 w., Sec. 11

7/10/79 1:52 PM

Logged by GeothermEx, Inc.

Depth, Depth, in feet in meters

$\begin{array}{rll}3.0 & 62.87 & 17.15 \\ 6.1 & 60.26 & 15.70 \\ 9.1 & 60.87 & 16.04 \\ 12.2 & 61.38 & 16.32 \\ 15.2 & 61.54 & 16.41 \\ 18.3 & 61.65 & 16.47 \\ 21.3 & 61.74 & 16.52 \\ 24.4 & 61.88 & 16.60 \\ 27.4 & 62.02 & 16.68 \\ 30.5 & 62.11 & 16.73 \\ 33.5 & 62.31 & 16.84 \\ 36.6 & 62.44 & 16.91 \\ 39.6 & 62.56 & 16.98 \\ 42.7 & 62.74 & 17.08 \\ 45.7 & 62.83 & 17.13 \\ 48.8 & 62.94 & 17.19 \\ 51.8 & 63.03 & 17.24 \\ 54.9 & 63.19 & 17.33 \\ 57.9 & 63.34 & 17.41 \\ 61.0 & 63.45 & 17.47 \\ 64.0 & 63.63 & 17.57 \\ 67.1 & 63.73 & 17.63 \\ 70.1 & 63.88 & 17.71 \\ 73.2 & 64.02 & 17.79 \\ 76.2 & 64.18 & 17.88\end{array}$

Depth, Depth, in feet in meters

$\begin{array}{lrll}260 & 79.2 & 64.35 & 17.97 \\ 270 & 82.3 & 64.47 & 18.04 \\ 280 & 85.3 & 64.63 & 18.13 \\ 290 & 88.4 & 64.76 & 18.20 \\ 300 & 91.4 & 64.92 & 18.29 \\ 310 & 94.5 & 65.08 & 18.38 \\ 320 & 97.5 & 65.25 & 18.47 \\ 330 & 100.6 & 65.39 & 18.55 \\ 340 & 103.6 & 65.57 & 18.65 \\ 350 & 106.7 & 65.77 & 18.76 \\ 360 & 109.7 & 65.91 & 18.84 \\ 370 & 112.8 & 66.00 & 18.89 \\ 380 & 115.8 & 66.16 & 18.98 \\ 390 & 118.9 & 66.38 & 19.10 \\ 400 & 121.9 & 66.56 & 19.20 \\ 410 & 125.0 & 66.72 & 19.29 \\ 420 & 128.0 & 66.88 & 19.38 \\ 430 & 131.1 & 67.05 & 19.47 \\ 440 & 134.1 & 67.21 & 19.56 \\ 450 & 137.2 & 67.41 & 19.67 \\ 460 & 140.2 & 67.57 & 19.76 \\ 470 & 143.3 & 67.71 & 19.84 \\ 480 & 146.3 & 67.89 & 19.94 \\ 490 & 149.4 & 68.05 & 20.03 \\ 496 & 151.2 & 68.09 & 20.05\end{array}$

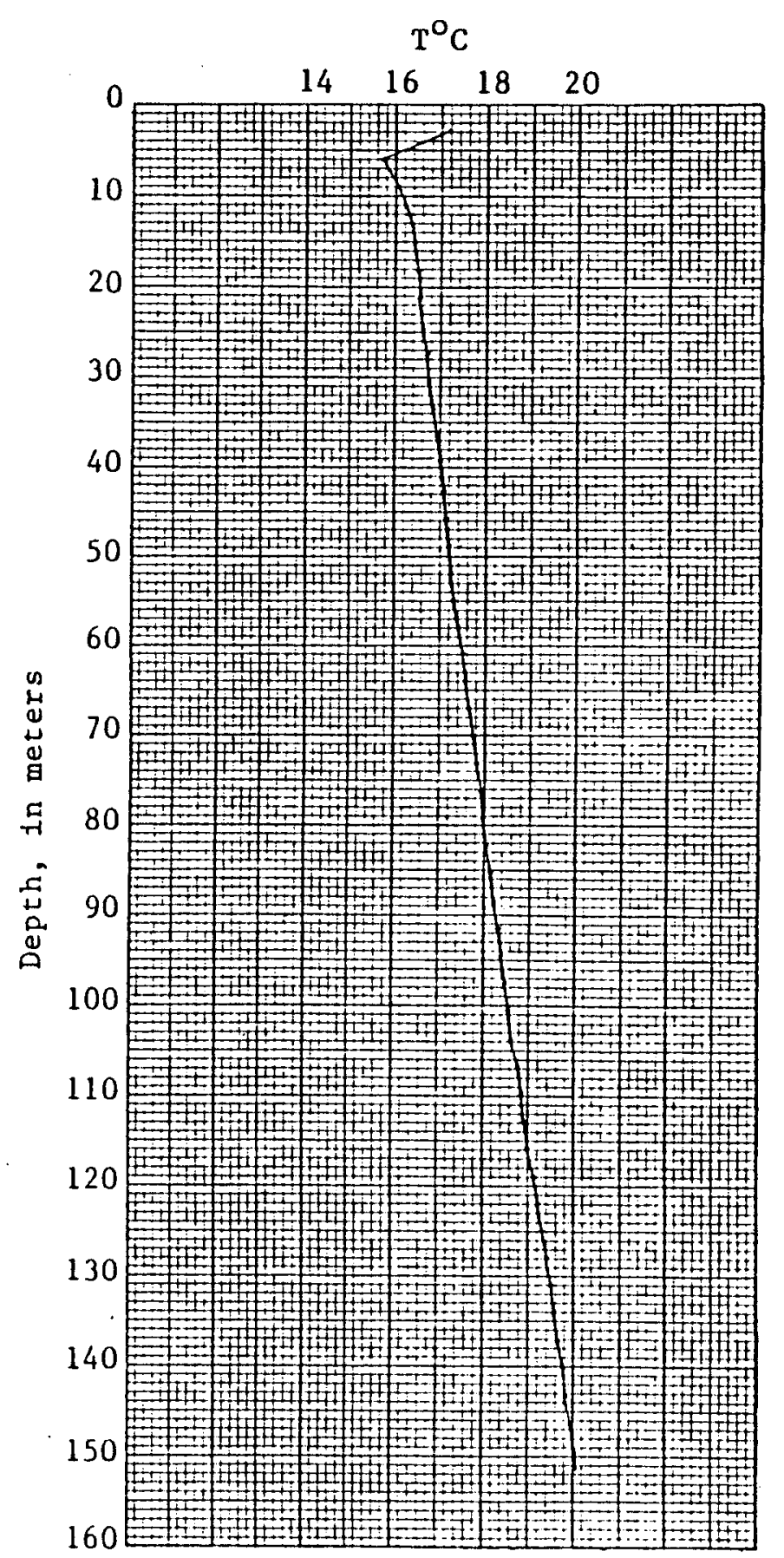


GULF MINERAL RESOURCES COMPANY

SOCORRO PROSPECT

T.G. HOLE STROZZI \#8

T. 3 S., R. 2 W., Sec. 11

7/10/79 3:04 PM

Logged by GeothermEx, Inc.

\begin{tabular}{|c|c|c|c|c|c|c|c|}
\hline $\begin{array}{l}\text { Depth, } \\
\text { In feet }\end{array}$ & $\begin{array}{c}\text { Depth, } \\
\text { in meters } \\
\end{array}$ & ${ }^{\circ} \mathrm{F}$ & ${ }^{\circ} \mathrm{C}$ & $\begin{array}{l}\text { Depth, } \\
\text { in feet } \\
\end{array}$ & $\begin{array}{c}\text { Depth, } \\
\text { in meters } \\
\end{array}$ & $o_{F}$ & ${ }^{\circ} \mathrm{C}$ \\
\hline 10 & 3.0 & 60.15 & 15.64 & 260 & 79.2 & 67.51 & 19.73 \\
\hline 20 & 6.1 & 60.64 & 15.91 & 270 & 82.3 & 67.77 & 19.87 \\
\hline 30 & 9.1 & 61.41 & 16.34 & 280 & 85.3 & 67.98 & 19.99 \\
\hline 40 & 12.2 & 61.95 & 16.64 & 290 & 88.4 & 68.27 & 20.15 \\
\hline 50 & 15.2 & 62.20 & 16.78 & 300 & 91.4 & 68.61 & 20.34 \\
\hline 60 & 18.3 & 62.56 & 16.98 & 310 & 94.5 & 68.76 & 20.42 \\
\hline 70 & 21.3 & 62.87 & 17.15 & 320 & 97.5 & 68.85 & 20.47 \\
\hline 80 & 24.4 & 63.23 & 17.35 & 330 & 100.6 & 69.12 & 20.62 \\
\hline 90 & 27.4 & 63.52 & 17.51 & 340 & 103.6 & 69.40 & 20.78 \\
\hline 100 & 30.5 & 63.84 & 17.69 & 350 & 106.7 & 69.64 & 20.91 \\
\hline 110 & 33.5 & 64.06 & 17.81 & 360 & 109.7 & 69.85 & 21.03 \\
\hline 120 & 36.6 & 64.29 & 17.94 & 370 & 112.8 & 70.14 & 21.19 \\
\hline 130 & 39.6 & 64.53 & 18.07 & 380 & 115.8 & 70.43 & 21.35 \\
\hline 140 & 42.7 & 64.78 & 18.21 & 390 & 118.9 & 70.61 & 21.45 \\
\hline 150 & 45.7 & 65.01 & 18.34 & 400 & 121.9 & 70.75 & 21.53 \\
\hline 160 & 48.8 & 65.26 & 18.48 & 410 & 125.0 & 70.93 & 21.63 \\
\hline 170 & 51.8 & 65.46 & 18.59 & 420 & 128.0 & 71.24 & 21.80 \\
\hline 180 & 54.9 & 65.66 & 18.70 & 430 & 131.1 & 71.49 & 21.94 \\
\hline 190 & 57.9 & 65.91 & 18.84 & 440 & 134.1 & 71.73 & 22.07 \\
\hline 200 & 61.0 & 66.13 & 18.96 & 450 & 137.2 & 71.98 & 22.21 \\
\hline 210 & 64.0 & 66.36 & 19.09 & 460 & 140.2 & 72.23 & 22.35 \\
\hline 220 & 67.1 & 66.58 & 19.21 & 470 & 143.3 & 72.48 & 22.49 \\
\hline 230 & 70.1 & 66.81 & 19.34 & 480 & 146.3 & 72.66 & 22.59 \\
\hline 240 & 73.2 & 67.03 & 19.46 & 481 & 146.6 & 72.70 & 22.61 \\
\hline
\end{tabular}


GULF MINERAL RESOURCES COMPANY

\section{SOCORRO PROSPECT}

\section{T.G. HOLE STROZZI \#9B}

T. 3 S., R. 2 W., Sec. 36

7/11/79 12:46 PM

Logged by GeothermEx, Inc.

Depth, Depth, in feet in meters

$\begin{array}{rrrr}10 & 3.0 & 64.53 & 18.07 \\ 20 & 6.1 & 61.77 & 16.54 \\ 30 & 9.1 & 62.44 & 16.91 \\ 40 & 12.2 & 63.27 & 17.37 \\ 50 & 15.2 & 63.91 & 17.73 \\ 60 & 18.3 & 64.15 & 17.86 \\ 70 & 21.3 & 64.40 & 18.00 \\ 80 & 24.4 & 64.65 & 18.14 \\ 90 & 27.4 & 64.96 & 18.31 \\ 100 & 30.5 & 65.35 & 18.53 \\ 110 & 33.5 & 65.77 & 18.76 \\ 120 & 36.6 & 66.06 & 18.92 \\ 130 & 39.6 & 66.27 & 19.04 \\ 140 & 42.7 & 66.54 & 19.19 \\ 150 & 45.7 & 66.83 & 19.35 \\ 160 & 48.8 & 67.10 & 19.50 \\ 170 & 51.8 & 67.35 & 19.64 \\ 180 & 54.9 & 67.64 & 19.80 \\ 190 & 57.9 & 67.93 & 19.96 \\ 200 & 61.0 & 68.18 & 20.10 \\ 210 & 64.0 & 68.45 & 20.25 \\ 220 & 67.1 & 68.70 & 20.39 \\ 230 & 70.1 & 69.03 & 20.57 \\ 240 & 73.2 & 69.24 & 20.69 \\ 250 & 76.2 & 69.49 & 20.83\end{array}$

Depth, Depth, in feet in meters ${ }^{{ }^{\circ} \mathrm{F}} \quad{ }^{\circ} \mathrm{C}$ 260

270

280

290

300

310

320

330

340

350

360

370

380

390

400

410

420

430

440

450

460

470

480

490

500

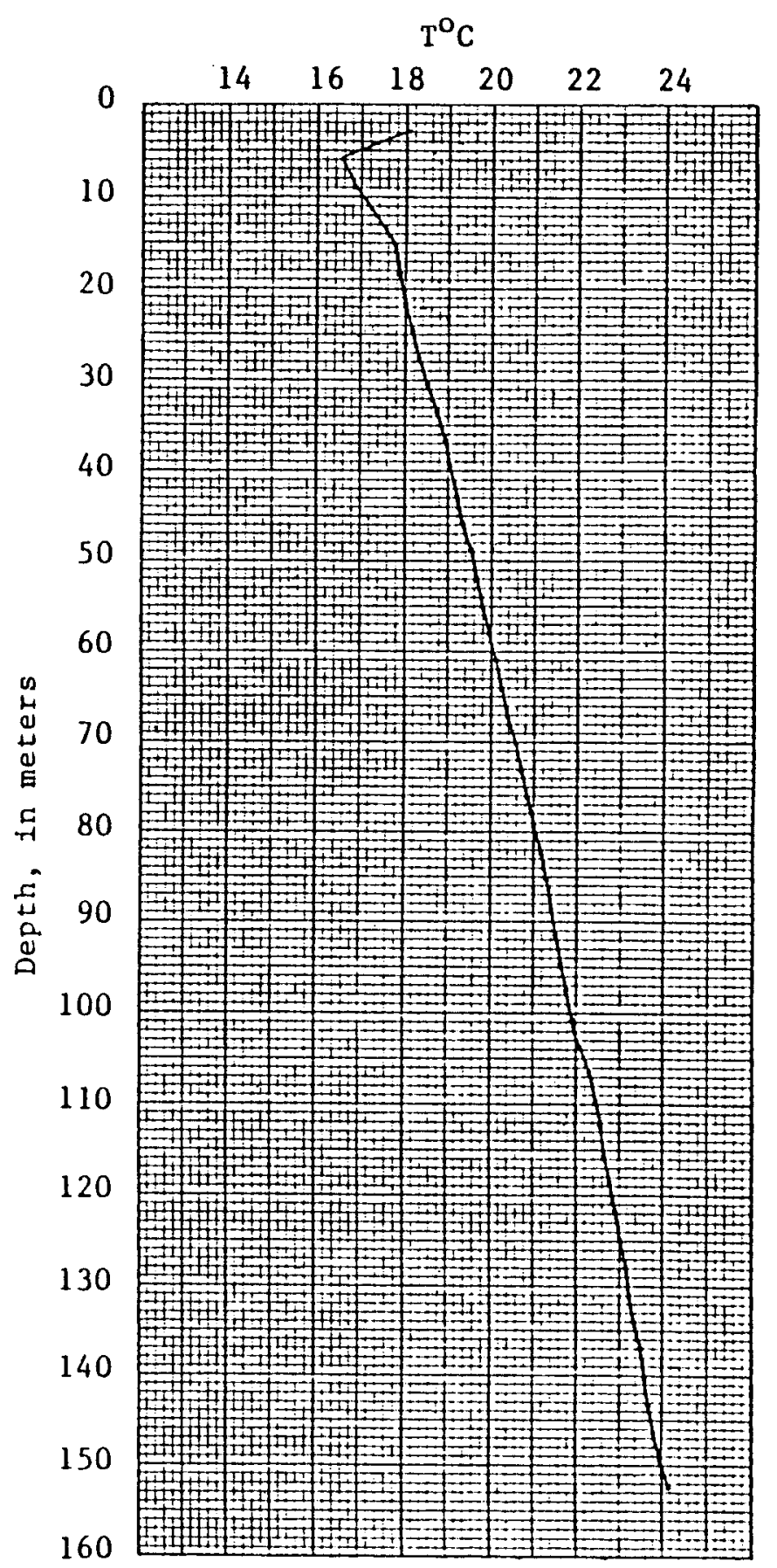




\section{GULF MINERAL RESOURCES COMPANY}

\section{SOCORRO PROSPECT}

T.G. HOLE ARMTJO \#1B

T. 4 S., R. 1 W., Sec. 5

7/11/79 6:06 PM

Logged by GeothermEx, Inc.
$\mathrm{T}^{\mathrm{O}} \mathrm{C}$

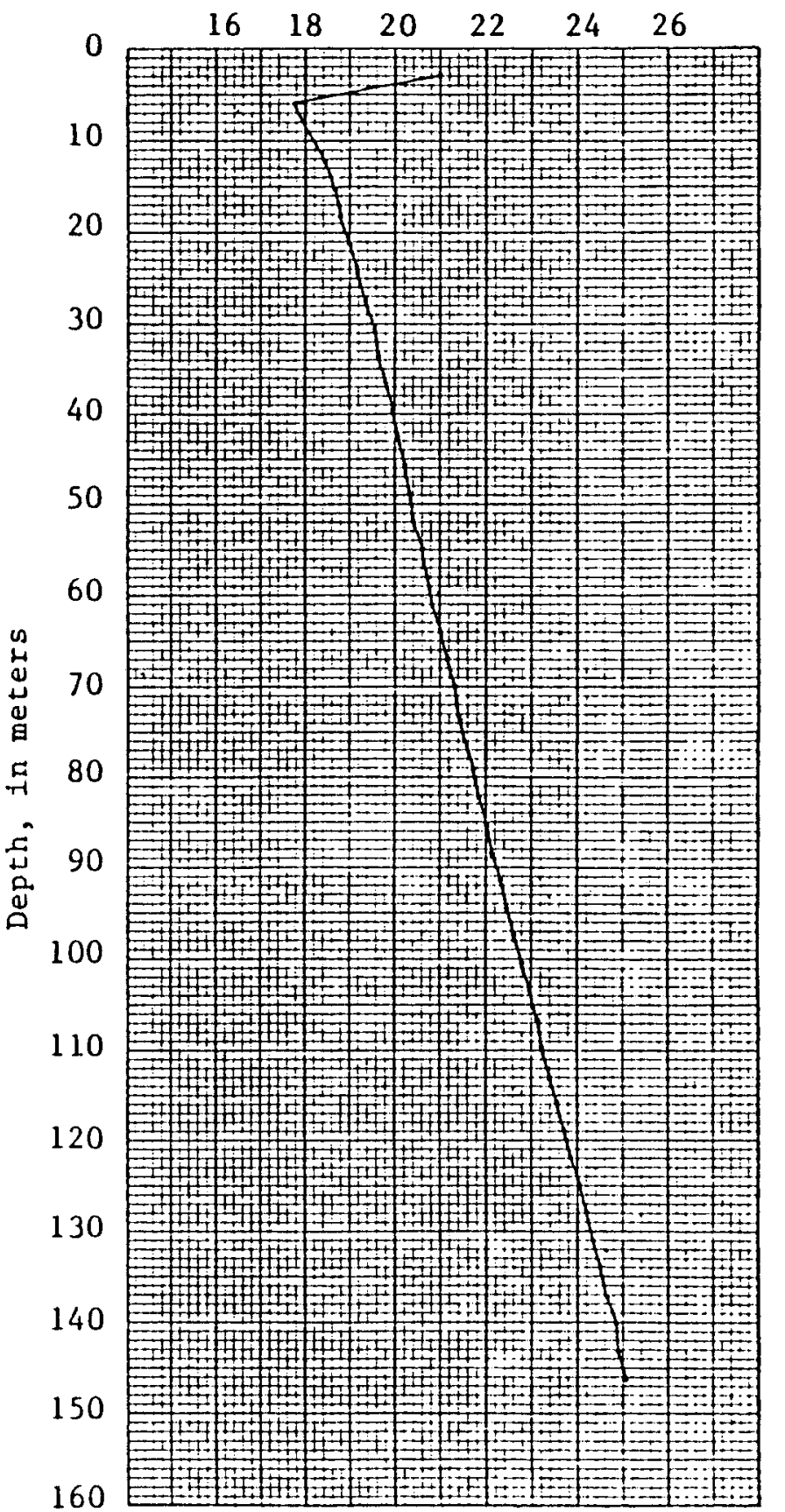

\begin{tabular}{|c|c|c|c|c|c|c|c|}
\hline $\begin{array}{l}\text { Depth, } \\
\text { in feet }\end{array}$ & $\begin{array}{c}\text { Depth, } \\
\text { in meters } \\
\end{array}$ & ${ }^{\circ} \mathrm{F}$ & ${ }^{\circ} \mathrm{C}$ & $\begin{array}{l}\text { Depth, } \\
\text { in feet }\end{array}$ & $\begin{array}{c}\text { Depth, } \\
\text { In meters } \\
\end{array}$ & $o_{F}$ & ${ }^{\circ} \mathrm{C}$ \\
\hline 10 & 3.0 & 69.80 & 21.00 & 250 & 76.2 & 70.77 & 21.54 \\
\hline 20 & 6.1 & 63.99 & 17.77 & 260 & 79.2 & 71.02 & 21.68 \\
\hline 30 & 9.1 & 64.53 & 18.07 & 270 & 82.3 & 71.29 & 21.83 \\
\hline 40 & 12.2 & 65.21 & 18.45 & 280 & 85.3 & 71.56 & 21.98 \\
\hline 50 & 15.2 & 65.53 & 18.63 & 290 & 88.4 & 71.82 & 22.12 \\
\hline 60 & 18.3 & 65.80 & 18.78 & 300 & 91.4 & 72.12 & 22.29 \\
\hline 70 & 21.3 & 66.16 & 18.98 & 310 & 94.5 & 72.39 & 22.44 \\
\hline 80 & 24.4 & 66.49 & 19.16 & 320 & 97.5 & 72.66 & 22.59 \\
\hline 90 & 27.4 & 66.85 & 19.36 & 330 & 100.6 & 72.99 & 22.77 \\
\hline 100 & 30.5 & 67.17 & 19.54 & 340 & 103.6 & 73.29 & 22.94 \\
\hline 110 & 33.5 & 67.41 & 19.67 & 350 & 106.7 & 73.56 & 23.09 \\
\hline 120 & 36.6 & 67.62 & 19.79 & 360 & 109.7 & 73.78 & 23.21 \\
\hline 130 & 39.6 & 67.89 & 19.94 & 370 & 112.8 & 74.10 & 23.39 \\
\hline 140 & 42.7 & 68.13 & 20.07 & 380 & 115.8 & 74.41 & 23.56 \\
\hline 150 & 45.7 & 68.38 & 20.21 & 390 & 118.9 & 74.68 & 23.71 \\
\hline 160 & 48.8 & 68.56 & 20.31 & 400 & 121.9 & 74.95 & 23.86 \\
\hline 170 & 51.8 & 68.76 & 20.42 & 410 & 125.0 & 75.25 & 24.03 \\
\hline 180 & 54.9 & 69.06 & 20.59 & 420 & 128.0 & 75.56 & 24.20 \\
\hline 190 & 57.9 & 69.28 & 20.71 & 430 & 131.1 & 75.79 & 24.33 \\
\hline 200 & 61.0 & 69.48 & 20.82 & 440 & 134.1 & 76.05 & 24.47 \\
\hline 210 & 64.0 & 69.76 & 20.98 & 450 & 137.2 & 76.37 & 24.65 \\
\hline 220 & 67.1 & 70.03 & 21.13 & 460 & 140.2 & 76.71 & 24.84 \\
\hline 230 & 70.1 & 70.30 & 21.28 & 470 & 143.3 & 76.82 & 24.90 \\
\hline 240 & 73.2 & 70.48 & 21.38 & 480 & 146.3 & 77.09 & 25.05 \\
\hline
\end{tabular}

Note: 10': afr-not stable 
GULF MINERAL RESOURCES COMPANY

\section{SOCORRO PROSPECT}

\section{T.G. HOLE ARMIJO \#2B}

T. 3 S., R. 1 W., Sec. 32

7/11/79 5:02 PM

Logged by GeothermEx, Inc.

Depth, Depth, in feet in meters

$\begin{array}{rrr}3.0 & 65.88 & 18.82 \\ 6.1 & 63.81 & 17.67 \\ 9.1 & 64.56 & 18.09 \\ 12.2 & 65.37 & 18.54 \\ 15.2 & 65.75 & 18.75 \\ 18.3 & 65.95 & 18.86 \\ 21.3 & 66.22 & 19.01 \\ 24.4 & 66.45 & 19.14 \\ 27.4 & 66.60 & 19.22 \\ 30.5 & 66.79 & 19.33 \\ 33.5 & 66.96 & 19.42 \\ 36.6 & 67.14 & 19.52 \\ 39.6 & 67.30 & 19.61 \\ 42.7 & 67.53 & 19.74 \\ 45.7 & 67.68 & 19.82 \\ 48.8 & 67.86 & 19.92 \\ 51.8 & 68.02 & 20.01 \\ 54.9 & 68.20 & 20.11 \\ 57.9 & 68.36 & 20.20 \\ 61.0 & 68.50 & 20.28 \\ 64.0 & 68.70 & 20.39 \\ 67.1 & 68.85 & 20.47 \\ 70.1 & 69.01 & 20.56 \\ 73.2 & 69.17 & 20.65 \\ 76.2 & 69.37 & 20.76\end{array}$

\begin{tabular}{|c|c|c|c|}
\hline $\begin{array}{l}\text { Depth, } \\
\text { In feet }\end{array}$ & $\begin{array}{c}\text { Depth, } \\
\text { in meters }\end{array}$ & ${ }^{\circ} \mathrm{F}$ & ${ }^{\circ} \mathrm{C}$ \\
\hline 260 & 79.2 & 69.51 & 20.84 \\
\hline 270 & 82.3 & 69.66 & 20.92 \\
\hline 280 & 85.3 & 69.91 & 21.06 \\
\hline 290 & 88.4 & 70.05 & 21.14 \\
\hline 300 & 91.4 & 70.16 & 21.20 \\
\hline 310 & 94.5 & 70.27 & 21.26 \\
\hline 320 & 97.5 & 70.41 & 21.34 \\
\hline 330 & 100.6 & 70.56 & 21.42 \\
\hline 340 & 103.6 & 70.70 & 21.50 \\
\hline 350 & 106.7 & 70.84 & 21.58 \\
\hline 360 & 109.7 & 70.99 & 21.66 \\
\hline 370 & 112.8 & 71.15 & 21.75 \\
\hline 380 & 115.8 & 71.35 & 21.86 \\
\hline 390 & 118.9 & 71.53 & 21.96 \\
\hline 400 & 121.9 & 71.73 & 22.07 \\
\hline 410 & 125.0 & 71.92 & 22.18 \\
\hline 420 & 128.0 & 72.12 & 22.29 \\
\hline 430 & 131.1 & 72.28 & 22.38 \\
\hline 440 & 134.1 & 72.48 & 22.49 \\
\hline 450 & 137.2 & 72.66 & 22.59 \\
\hline 460 & 140.2 & 72.84 & 22.69 \\
\hline 470 & 143.3 & 73.00 & 22.78 \\
\hline 480 & 146.3 & 73.17 & 22.87 \\
\hline 490 & 149.4 & 73.33 & 22.96 \\
\hline 500 & 152.4 & 73.42 & 23.01 \\
\hline
\end{tabular}

$\mathrm{T}^{\mathrm{O}} \mathrm{C}$

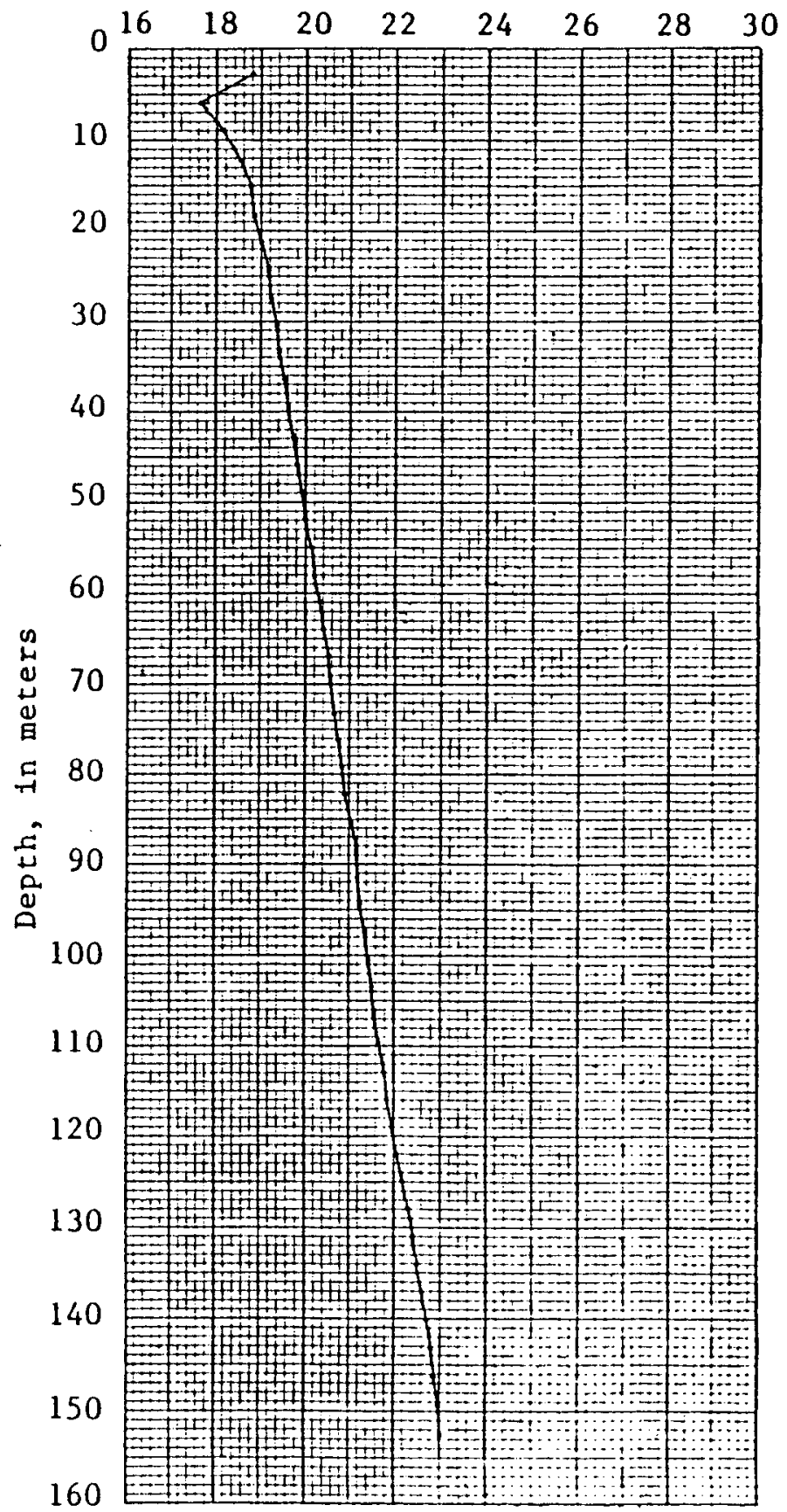


GULF MINERAL RESOURCES COMPANY

\section{SOCORRO PROSPECT}

T.G. HOLE ARMIJO \#3

T. 3 S., R. 1 W., Sec. 32

7/11/79 3:29 PM

Logged by GeothermEx, Inc.

Depth, Depth

in feet in meters ${ }^{\circ} \mathrm{F} \quad{ }^{\circ} \mathrm{C}$

$\begin{array}{rrrr}10 & 3.0 & 63.50 & 17.50 \\ 20 & 6.1 & 63.57 & 17.54 \\ 30 & 9.1 & 64.80 & 18.22 \\ 40 & 12.2 & 65.80 & 18.78 \\ 50 & 15.2 & 66.47 & 19.15 \\ 60 & 18.3 & 67.08 & 19.49 \\ 70 & 21.3 & 67.62 & 19.79 \\ 80 & 24.4 & 68.16 & 20.09 \\ 90 & 27.4 & 68.74 & 20.41 \\ 100 & 30.5 & 69.24 & 20.69 \\ 110 & 33.5 & 69.87 & 21.04 \\ 120 & 36.6 & 70.39 & 21.33 \\ 130 & 39.6 & 70.92 & 21.62 \\ 140 & 42.7 & 71.38 & 21.88 \\ 150 & 45.7 & 71.92 & 22.18 \\ 160 & 48.8 & 72.43 & 22.46 \\ 170 & 51.8 & 72.86 & 22.70 \\ 180 & 54.9 & 73.27 & 22.93 \\ 190 & 57.9 & 73.76 & 23.20 \\ 200 & 61.0 & 74.21 & 23.45 \\ 210 & 64.0 & 74.62 & 23.68 \\ 220 & 67.1 & 75.02 & 23.90 \\ 230 & 70.1 & 75.43 & 24.13 \\ 240 & 73.2 & 75.87 & 24.37 \\ 250 & 76.2 & 76.23 & 24.57\end{array}$

\begin{tabular}{|c|c|c|c|}
\hline $\begin{array}{l}\text { Depth, } \\
\text { in feet }\end{array}$ & $\begin{array}{c}\text { Depth, } \\
\text { in meters } \\
\end{array}$ & ${ }^{o} \mathrm{~F}$ & ${ }^{\circ} \mathrm{C}$ \\
\hline 260 & 79.2 & 76.62 & 24.79 \\
\hline 270 & 82.3 & 76.95 & 24.97 \\
\hline 280 & 85.3 & 77.36 & 25.20 \\
\hline 290 & 88.4 & 77.76 & 25.42 \\
\hline 300 & 91.4 & 77.97 & 25.54 \\
\hline 310 & 94.5 & 78.19 & 25.66 \\
\hline 320 & 97.5 & 78.48 & 25.82 \\
\hline 330 & 100.6 & 78.71 & 25.95 \\
\hline 340 & 103.6 & 78.96 & 26.09 \\
\hline 350 & 106.7 & 79.21 & 26.23 \\
\hline 360 & 109.7 & 79.36 & 26.31 \\
\hline 370 & 112.8 & 79.65 & 26.47 \\
\hline 380 & 115.8 & 79.86 & 26.59 \\
\hline 390 & 118.9 & 80.06 & 26.70 \\
\hline 400 & 121.9 & 80.24 & 26.80 \\
\hline 410 & 125.0 & 80.37 & 26.87 \\
\hline 420 & 128.0 & 80.49 & 26.94 \\
\hline 430 & 131.1 & 80.62 & 27.01 \\
\hline 440 & 134.1 & 80.73 & 27.07 \\
\hline 450 & 137.2 & 80.82 & 27.12 \\
\hline 460 & 140.2 & 80.89 & 27.16 \\
\hline 470 & 143.3 & 80.94 & 27.19 \\
\hline 480 & 146.3 & 80.98 & 27.21 \\
\hline 490 & 149.4 & 81.00 & 27.22 \\
\hline 500 & 152.4 & 81.01 & 27.23 \\
\hline
\end{tabular}

$\mathrm{T}^{\circ} \mathrm{C}$

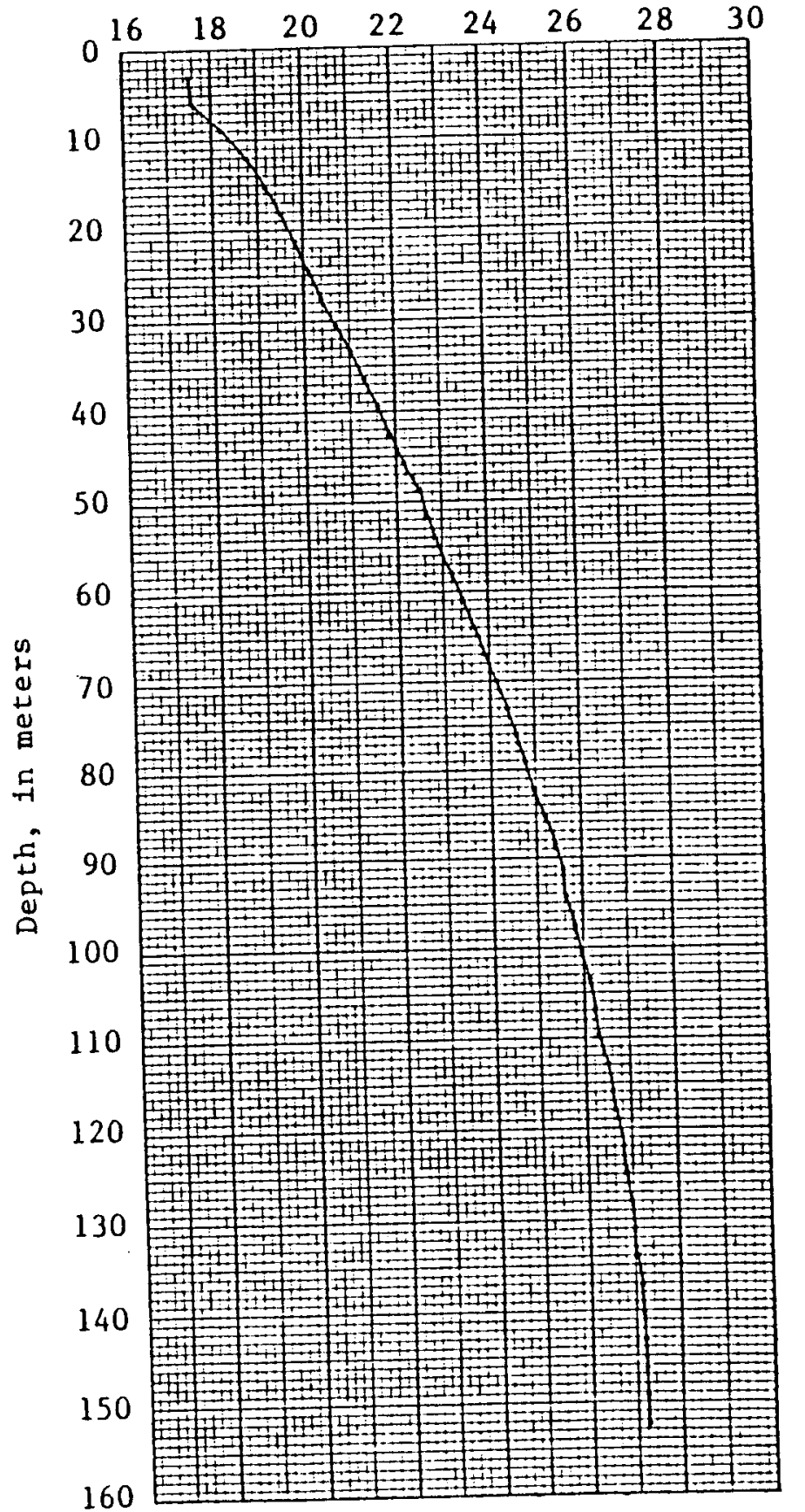


GULF MINERAL RESOURCES COMPANY

\section{SOCORRO PROSPECT}

\section{T.G. HOLE ARMIJO \#4}

T. 3 S., R. 2 W., Sec. 35

7/10/79 8:32 AM

Logged by GeothermEx, Inc.

\begin{tabular}{|c|c|c|c|c|c|c|c|}
\hline $\begin{array}{l}\text { Depth, } \\
\text { in feet }\end{array}$ & $\begin{array}{c}\text { Depth, } \\
\text { in meters }\end{array}$ & ${ }^{\circ} \mathrm{F}$ & ${ }^{\circ} \mathrm{C}$ & $\begin{array}{l}\text { Depth, } \\
\text { in feet }\end{array}$ & $\begin{array}{c}\text { Depth, } \\
\text { In meters }\end{array}$ & ${ }^{o} \mathrm{~F}$ & ${ }^{\circ} \mathrm{C}$ \\
\hline 10 & 3.0 & 66.02 & 18.90 & 240 & 73.2 & 64.92 & 18.29 \\
\hline 20 & 6.1 & 64.04 & 17.80 & 250 & 76.2 & 65.07 & 18.37 \\
\hline 30 & 9.1 & 63.68 & 17.60 & 260 & 79.2 & 65.19 & 18.44 \\
\hline 40 & 12.2 & 64.04 & 17.80 & 270 & 82.3 & 65.34 & 18.52 \\
\hline 50 & 15.2 & 64.04 & 17.80 & 280 & 85.3 & 65.48 & 18.60 \\
\hline 60 & 18.3 & 63.86 & 17.70 & 290 & 88.4 & 65.62 & 18.68 \\
\hline 70 & 21.3 & 63.82 & 17.68 & 300 & 91.4 & 65.73 & 18.74 \\
\hline 80 & 24.4 & 63.75 & 17.64 & 310 & 94.5 & 65.89 & 18.83 \\
\hline 90 & 27.4 & 63.75 & 17.64 & 320 & 97.5 & 66.04 & 18.91 \\
\hline 100 & 30.5 & 63.75 & 17.64 & 330 & 100.6 & 66.22 & 19.01 \\
\hline 110 & 33.5 & 63.75 & 17.64 & 340 & 103.6 & 66.40 & 19.11 \\
\hline 120 & 36.6 & 63.77 & 17.65 & 350 & 106.7 & 66.56 & 19.20 \\
\hline 130 & 39.6 & 63.79 & 17.66 & 360 & 109.7 & 66.70 & 19.28 \\
\hline 140 & 42.7 & 63.81 & 17.67 & 370 & 112.8 & 66.88 & 19.38 \\
\hline 150 & 45.7 & 63.88 & 17.71 & 380 & 115.8 & 67.06 & 19.48 \\
\hline 160 & 48.8 & 64.04 & 17.80 & 390 & 118.9 & 67.24 & 19.58 \\
\hline 170 & 51.8 & 64.15 & 17.86 & 400 & 121.9 & 67.41 & 19.67 \\
\hline 180 & 54.9 & 64.22 & 17.90 & 410 & 125.0 & 67.59 & 19.77 \\
\hline 190 & 57.9 & 64.31 & 17.95 & 420 & 128.0 & 67.75 & 19.86 \\
\hline 200 & 61.0 & 64.44 & 18.02 & 430 & 131.1 & 67.93 & 19.96 \\
\hline 210 & 64.0 & 64.54 & 18.08 & 440 & 134.1 & 68.14 & 20.08 \\
\hline 220 & 67.1 & 64.65 & 18.14 & 450 & 137.2 & 68.34 & 20.19 \\
\hline 230 & 70.1 & 64.81 & 18.23 & 460 & 140.2 & 68.45 & 20.25 \\
\hline
\end{tabular}

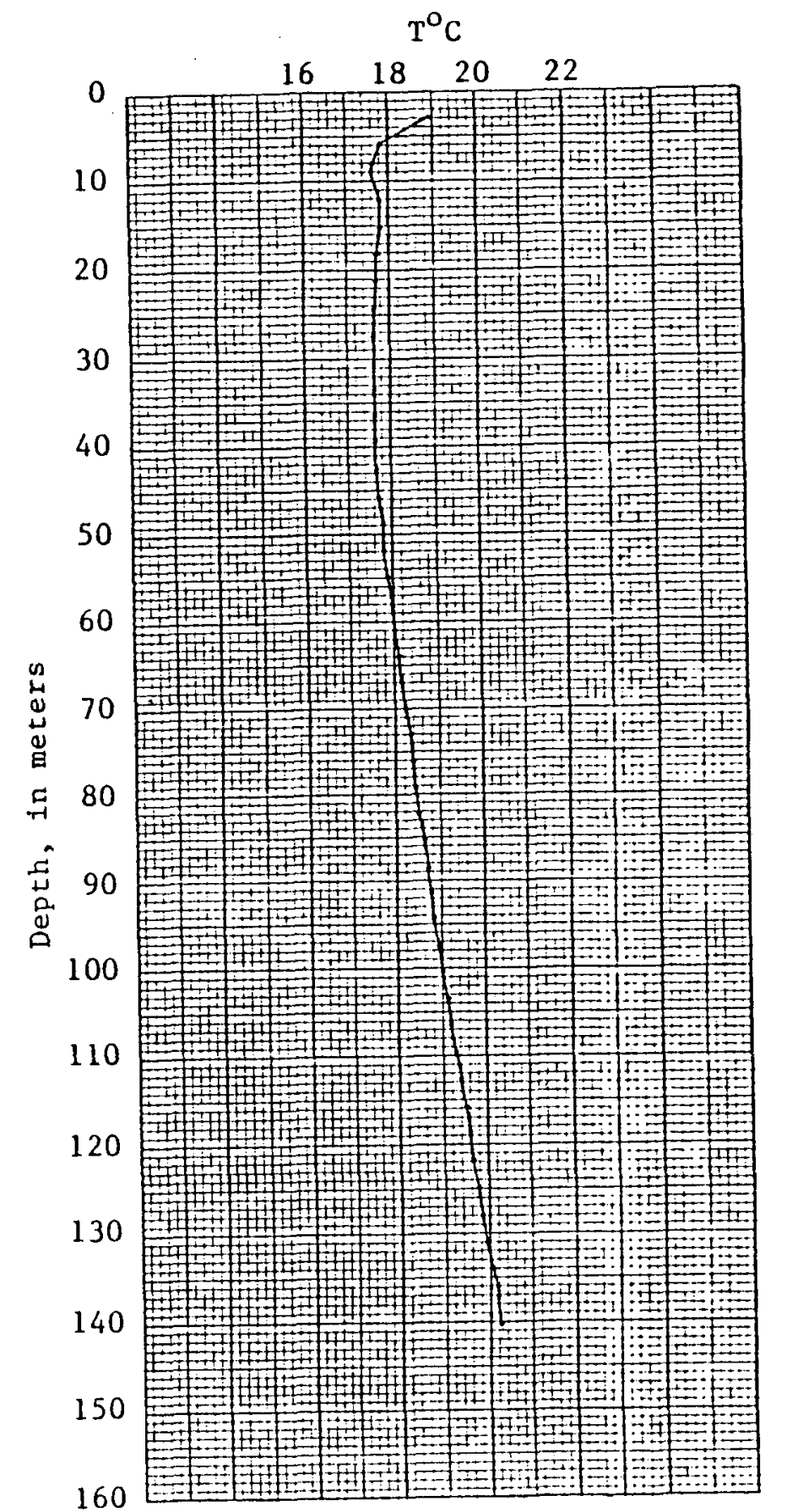

Note: 10-90': pipe dry - readings unstable 
GULF MINERAL RESOURCES COMPANY

\section{SOCORRO PROSPECT}

\section{T.G. HOLE ARMIJO 非}

T. 3 S., R. 2 W., Sec. 26

7/11/79 11:27 AM

Logged by GeothermEx, Inc.

\begin{tabular}{|c|c|c|c|c|c|c|c|}
\hline $\begin{array}{l}\text { Depth, } \\
\text { In feet }\end{array}$ & $\begin{array}{c}\text { Depth, } \\
\text { in meters } \\
\end{array}$ & ${ }^{\circ} \mathrm{F}$ & ${ }^{\circ} \mathrm{C}$ & $\begin{array}{l}\text { Depth, } \\
\text { in feet }\end{array}$ & $\begin{array}{c}\text { Depth, } \\
\text { in meters }\end{array}$ & $o_{F}$ & ${ }^{\circ} \mathrm{C}$ \\
\hline 10 & 3.0 & 62.83 & 17.13 & 260 & 79.2 & 64.80 & 18.22 \\
\hline 20 & 6.1 & 61.59 & 16.44 & 270 & 82.3 & 64.89 & 18.27 \\
\hline 30 & 9.1 & 61.95 & 16.64 & 280 & 85.3 & 64.98 & 18.32 \\
\hline 40 & 12.2 & 62.38 & 16.88 & 290 & 88.4 & 65.08 & 18.38 \\
\hline 50 & 15.2 & 62.80 & 17.11 & 300 & 91.4 & 65.19 & 18.44 \\
\hline 60 & 18.3 & 62.91 & 17.17 & 310 & 94.5 & 65.30 & 18.50 \\
\hline 70 & 21.3 & 62.98 & 17.21 & 320 & 97.5 & 65.44 & 18.58 \\
\hline 80 & 24.4 & 63.05 & 17.25 & 330 & 100.6 & 65.55 & 18.64 \\
\hline 90 & 27.4 & 63.21 & 17.34 & 340 & 103.6 & 65.66 & 18.70 \\
\hline 100 & 30.5 & 63.48 & 17.49 & 350 & 106.7 & 65.79 & 18.77 \\
\hline 110 & 33.5 & 63.84 & 17.69 & 360 & 109.7 & 65.95 & 18.86 \\
\hline 120 & 36.6 & 63.84 & 17.69 & 370 & 112.8 & 66.11 & 18.95 \\
\hline 130 & 39.6 & 63.73 & 17.63 & 380 & 115.8 & 66.25 & 19.03 \\
\hline 140 & 42.7 & 63.88 & 17.71 & 390 & 118.9 & 66.40 & 19.11 \\
\hline 150 & 45.7 & 64.02 & 17.79 & 400 & 121.9 & 66.58 & 19.21 \\
\hline 160 & 48.8 & 63.99 & 17.77 & 410 & 125.0 & 66.74 & 19.30 \\
\hline 170 & 51.8 & 64.02 & 17.79 & 420 & 128.0 & 66.92 & 19.40 \\
\hline 180 & 54.9 & 64.08 & 17.82 & 430 & 131.1 & 67.15 & 19.53 \\
\hline 190 & 57.9 & 64.18 & 17.88 & 440 & 134.1 & 67.32 & 19.62 \\
\hline 200 & 61.0 & 64.26 & 17.92 & 450 & 137.2 & 67.41 & 19.67 \\
\hline 210 & 64.0 & 64.35 & 17.97 & 460 & 140.2 & 67.59 & 19.77 \\
\hline 220 & 67.1 & 64.45 & 18.03 & 470 & 143.3 & 67.78 & 19.88 \\
\hline 230 & 70.1 & 64.54 & 18.08 & 480 & 146.3 & 67.96 & 19.98 \\
\hline 240 & 73.2 & 64.63 & 18.13 & 490 & 149.4 & 68.14 & 20.08 \\
\hline 250 & 76.2 & 64.71 & 18.17 & 497 & 151.5 & 68.27 & 20.15 \\
\hline
\end{tabular}

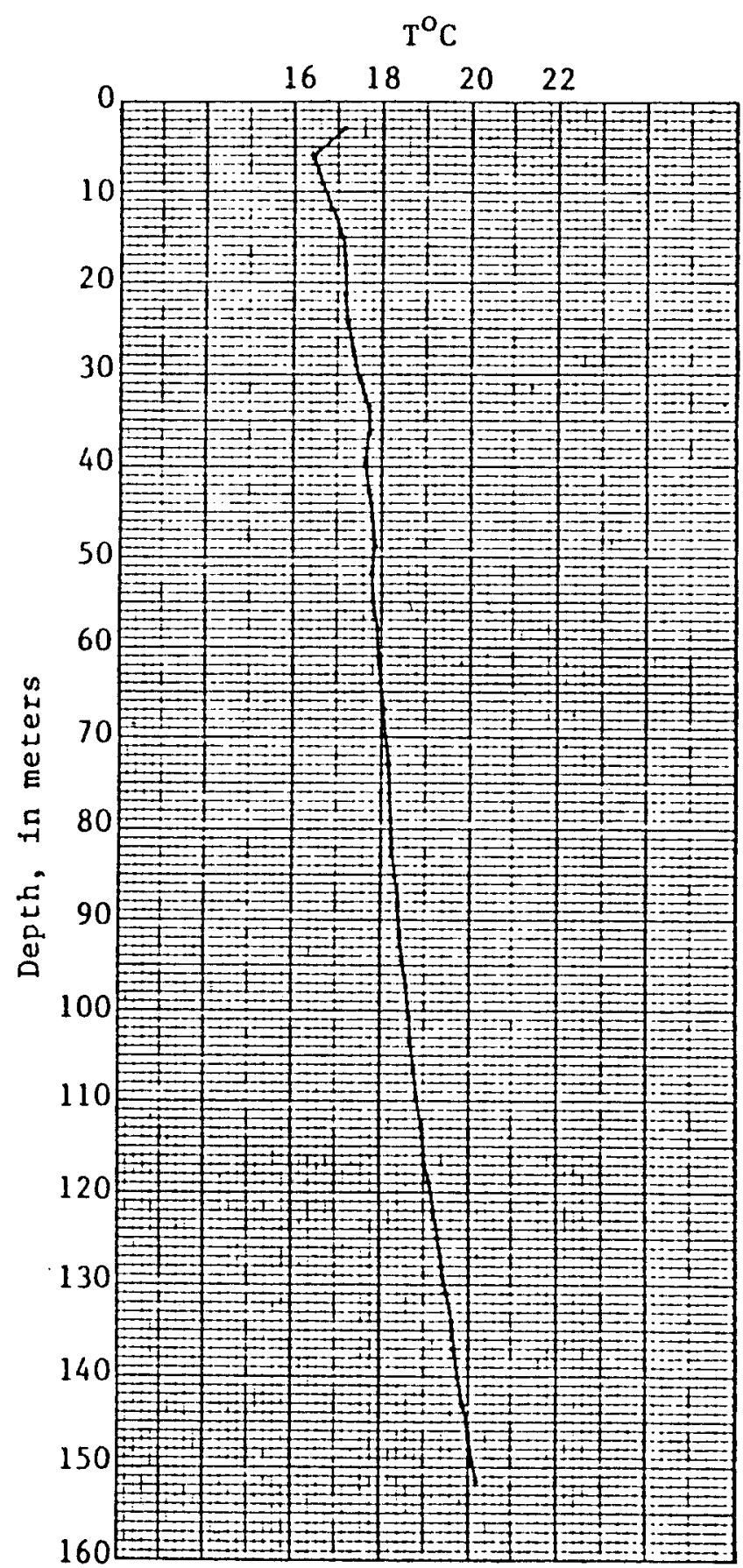


GULF MINERAL RESOURCES COMPANY

\section{SOCORRO PROSPECT}

\section{T.G. HOLE ARMIJO \#6B}

T. 3 S., R. 2 W., Sec. 25

7/10/79 4:51 PM

Logged by GeothermEx, Inc.

\begin{tabular}{|c|c|c|c|c|c|c|c|}
\hline $\begin{array}{l}\text { Depth, } \\
\text { in feet }\end{array}$ & $\begin{array}{c}\text { Depth, } \\
\text { in meters } \\
\end{array}$ & ${ }^{\circ} \mathrm{F}$ & ${ }^{\circ} \mathrm{C}$ & $\begin{array}{l}\text { Depth, } \\
\text { In feet }\end{array}$ & $\begin{array}{c}\text { Depth, } \\
\text { in meters }\end{array}$ & ${ }^{\circ} \mathrm{F}$ & ${ }^{\circ} \mathrm{C}$ \\
\hline 10 & 3.0 & $-\cdots$ & --- & 240 & 73.2 & 67.12 & 19.51 \\
\hline 20 & 6.1 & 61.74 & 16.52 & 250 & 76.2 & 67.37 & 19.65 \\
\hline 30 & 9.1 & 62.15 & 16.75 & 260 & 79.2 & 67.53 & 19.74 \\
\hline 40 & 12.2 & 63.03 & 17.24 & 270 & 82.3 & 67.82 & 19.90 \\
\hline 50 & 15.2 & 63.41 & 17.45 & 280 & 85.3 & 68.05 & 20.03 \\
\hline 60 & 18.3 & 63.59 & 17.55 & 290 & 88.4 & 68.22 & 20.12 \\
\hline 70 & 21.3 & 63.75 & 17.64 & 300 & 91.4 & 68.49 & 20.27 \\
\hline 80 & 24.4 & 63.99 & 17.77 & 310 & 94.5 & 68.72 & 20.40 \\
\hline 90 & 27.4 & 64.24 & 17.91 & 320 & 97.5 & 68.90 & 20.50 \\
\hline 100 & 30.5 & 64.44 & 18.02 & 330 & 100.6 & 69.15 & 20.64 \\
\hline 110 & 33.5 & 64.65 & 18.14 & 340 & 103.6 & 69.35 & 20.75 \\
\hline 120 & 36.6 & 64.85 & 18.25 & 350 & 106.7 & 69.57 & 20.87 \\
\hline 130 & 39.6 & 64.99 & 18.33 & 360 & 109.7 & 69.84 & 21.02 \\
\hline 140 & 42.7 & 65.17 & 18.43 & 370 & 112.8 & 70.05 & 21.14 \\
\hline 150 & 45.7 & 65.37 & 18.54 & 380 & 115.8 & 70.30 & 21.28 \\
\hline 160 & 48.8 & 65.59 & 18.66 & 390 & 118.9 & 70.54 & 21.41 \\
\hline 170 & 51.8 & 65.75 & 18.75 & 400 & 121.9 & 70.79 & 21.55 \\
\hline 180 & 54.9 & 66.02 & 18.90 & 410 & 125.0 & 71.01 & 21.67 \\
\hline 190 & 57.9 & 66.15 & 18.97 & 420 & 128.0 & 71.20 & 21.78 \\
\hline 200 & 61.0 & 66.27 & 19.04 & 430 & 131.1 & 71.44 & 21.91 \\
\hline 210 & 64.0 & 66.47 & 19.15 & 440 & 134.1 & 71.65 & 22.03 \\
\hline 220 & 67.1 & 66.74 & 19.30 & 450 & 137.2 & 71.87 & 22.15 \\
\hline 230 & 70.1 & 66.97 & 19.43 & 460 & 140.2 & 72.09 & 22.27 \\
\hline
\end{tabular}

${ }^{\circ} \mathrm{C}$

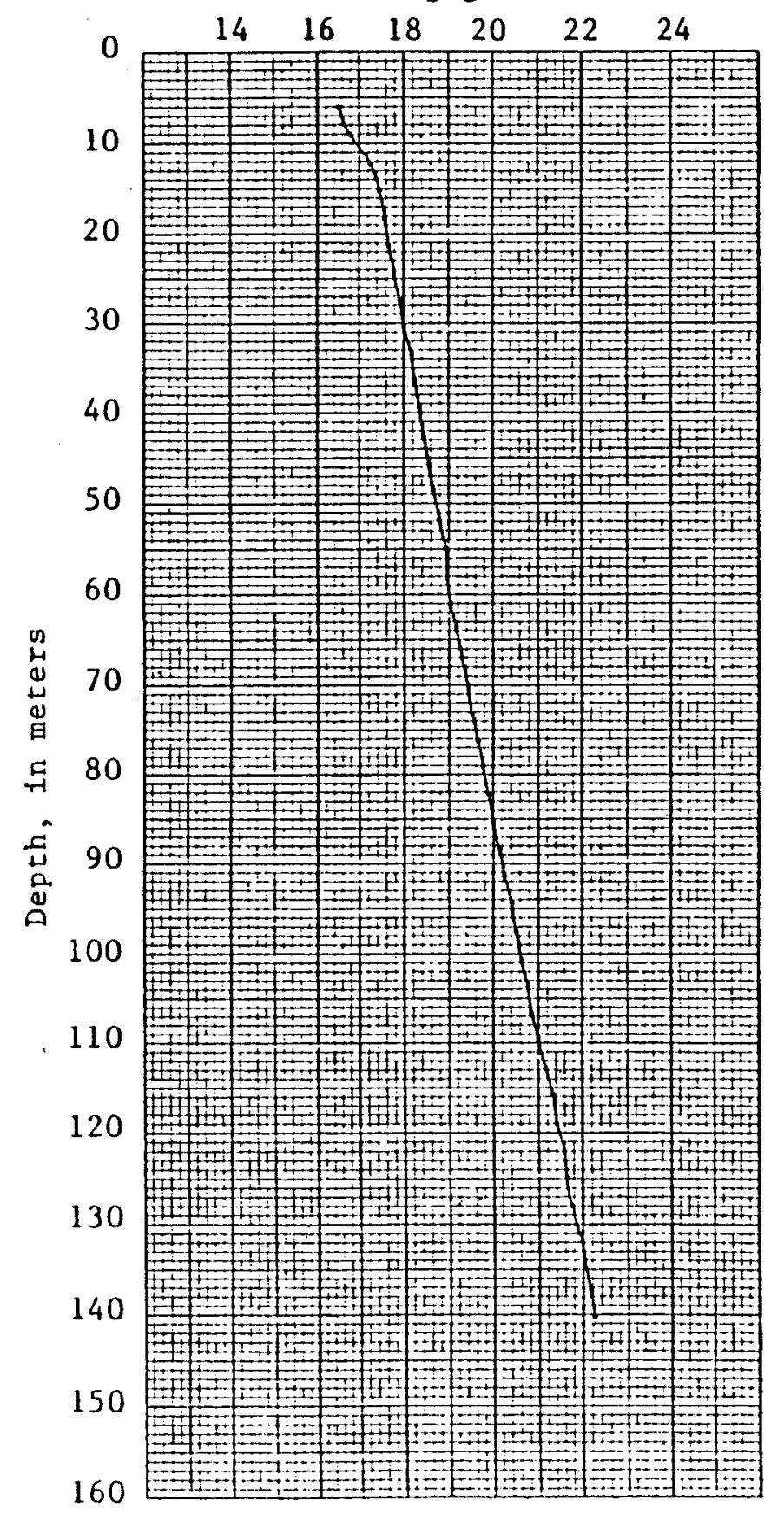

